Supplement of Atmos. Chem. Phys., 22, 505-533, 2022

https://doi.org/10.5194/acp-22-505-2022-supplement

(C) Author(s) 2022. CC BY 4.0 License.

(c) (i)

Atmospheric
Chemistry
and Physics

Supplement of

\title{
Insights into tropical cloud chemistry in Réunion (Indian Ocean): results from the BIO-MAÏDO campaign
}

Pamela A. Dominutti et al.

Correspondence to: Laurent Deguillaume (laurent.deguillaume@uca.fr) and Pamela A. Dominutti (pamela.dominutti@uca.fr)

The copyright of individual parts of the supplement might differ from the article licence. 
Table S1. Overview of chemical analysis and observed data for each cloud event collected at Reunion Island. Gas-phase measurements were performed in parallel to the cloud water sampling.

\begin{tabular}{|c|c|c|c|c|c|c|c|c|c|c|c|c|c|c|}
\hline \multirow[b]{2}{*}{ Measurement } & \multicolumn{14}{|c|}{ Cloud Event } \\
\hline & R1 & $\mathbf{R 2}$ & $\mathbf{R 3}$ & $\mathbf{R 4}$ & R5 & R6 & R7 & $\mathbf{R 8}$ & R9 & R10A & R10B & R11 & R12 & R13 \\
\hline Ions & $\mathbf{x}$ & $\mathbf{x}$ & $\mathbf{x}$ & $\mathbf{x}$ & $\mathbf{x}$ & $\mathbf{x}$ & $\mathbf{x}^{*}$ & $\mathbf{x}$ & $\mathbf{x}$ & $\mathbf{x}^{*}$ & $\mathbf{x}$ & $\mathbf{x}$ & $\mathbf{x}^{*}$ & $\mathbf{x}$ \\
\hline Metals & $\mathbf{x}$ & $\mathbf{x}$ & & $\mathbf{x}$ & $\mathbf{x}$ & & & $\mathbf{x}$ & & $\mathbf{x}$ & $\mathbf{x}$ & $\mathbf{x}$ & $\mathbf{x}$ & $\mathbf{x}$ \\
\hline$F e(I I), F e(I I I)$ & $\mathbf{x}$ & $\mathbf{x}$ & $\mathbf{x}$ & $\mathbf{x}$ & $\mathbf{x}$ & $\mathbf{x}$ & $\mathbf{x}$ & $\mathbf{x}$ & $\mathbf{x}$ & $\mathbf{x}$ & $\mathbf{x}$ & $\mathbf{x}$ & $\mathbf{x}$ & $\mathbf{x}$ \\
\hline $\mathrm{H}_{2} \mathrm{O}_{2}$ & $\mathbf{x}$ & $\mathbf{x}$ & $\mathbf{x}$ & $\mathbf{x}$ & $\mathbf{x}$ & & $\mathbf{x}$ & $\mathbf{x}$ & $\mathbf{x}$ & $\mathbf{x}$ & $\mathbf{x}$ & $\mathbf{x}$ & & $\mathbf{x}$ \\
\hline TOC, IC, TIC & $\mathbf{x}$ & $\mathbf{x}$ & $\mathbf{x}$ & $\mathbf{x}$ & $\mathbf{x}$ & $\mathbf{x}$ & & $\mathbf{x}$ & $\mathbf{x}$ & $\mathbf{x}$ & $\mathbf{x}$ & $\mathbf{x}$ & $\mathbf{x}$ & $\mathbf{x}$ \\
\hline Carboxylic acids & $\mathbf{x}$ & $\mathbf{x}$ & $\mathbf{x}$ & $\mathbf{x}$ & $\mathbf{x}$ & $\mathbf{x}$ & $\mathbf{x}^{+}$ & $\mathbf{x}$ & $\mathbf{x}$ & $\mathbf{x}^{+}$ & $\mathbf{x}$ & $\mathbf{x}$ & $\mathbf{x}^{+}$ & $\mathbf{x}$ \\
\hline Amino acids & $\mathbf{x}$ & $\mathbf{x}$ & $\mathbf{x}$ & $\mathbf{x}$ & $\mathbf{x}$ & & $\mathbf{x}$ & $\mathbf{x}$ & $\mathbf{x}$ & $\mathbf{x}$ & $\mathbf{x}$ & $\mathbf{x}$ & $\mathbf{x}$ & $\mathbf{x}$ \\
\hline Carbonyls (OVOCs) & $\mathbf{x}$ & $\mathbf{x}$ & & $\mathbf{x}$ & $\mathbf{x}$ & $\mathbf{x}$ & $\mathbf{x}$ & $\mathbf{x}$ & $\mathbf{x}$ & & $\mathbf{x}$ & $\mathbf{x}$ & & $\mathbf{x}$ \\
\hline Sugars & $\mathbf{x}$ & $\mathbf{x}$ & $\mathbf{x}$ & $\mathbf{x}$ & $\mathbf{x}$ & $\mathbf{x}$ & & $\mathbf{x}$ & $\mathbf{x}$ & & $\mathbf{x}$ & $\mathbf{x}$ & & $\mathbf{x}$ \\
\hline Physical parameters & $\mathbf{x}$ & $\mathbf{x}$ & $\mathbf{x}$ & $\mathbf{x}$ & $\mathbf{x}$ & $\mathbf{x}$ & $\mathbf{x}$ & $\mathbf{x}$ & $\mathbf{x}$ & $\mathbf{x}$ & $\mathbf{x}$ & $\mathbf{x}$ & $\mathbf{x}$ & $\mathbf{x}$ \\
\hline Gas-phase OVOCs & & & $\mathbf{x}$ & $\mathbf{x}$ & $\mathbf{x}$ & $\mathbf{x}$ & & $\mathbf{x}$ & $\mathbf{x}$ & $\mathbf{x}$ & & & & \\
\hline Gas-phase VOCs & $\mathbf{x}$ & $\mathbf{x}$ & $\mathbf{x}$ & $\mathbf{x}$ & & $\mathbf{x}$ & & $\mathbf{x}$ & $\mathbf{x}$ & & $\mathbf{x}$ & $\mathbf{x}$ & $\mathbf{x}$ & $\mathbf{x}$ \\
\hline VOCs & $\mathbf{x}$ & $\mathbf{x}$ & & & $\mathbf{x}$ & $\mathbf{x}$ & $\mathbf{x}$ & $\mathbf{x}$ & $\mathbf{x}$ & & $\mathbf{x}$ & $\mathbf{x}$ & & $\mathbf{x}$ \\
\hline
\end{tabular}

*except for MSA and Br-.

+except for oxalic and lactic acids. 
Table S2. Analytical method used, limit of detection, limit of quantification, and uncertainties of each chemical species analysed during BIO-MAÏDO field campaign. $M W=$ mass weight, $L O Q=$ limit of quantification, $L O D=$ limit of detection.

\begin{tabular}{|c|c|c|c|c|c|c|}
\hline \multirow{2}{*}{ Group } & \multirow{2}{*}{ Compound } & \multirow{2}{*}{ Instrument } & $\mathrm{g} \mathrm{mol}^{-1}$ & $\mu \mathrm{mol} \mathrm{L} \mathrm{L}^{-1}$ & \multirow[t]{2}{*}{ nmol $L^{-1}$} & \multirow{2}{*}{$\begin{array}{c}\text { Uncertainty } \\
(\%)\end{array}$} \\
\hline & & & MW & LOQ & & \\
\hline \multirow{9}{*}{ Ions } & $\mathrm{Cl}^{-}$ & ICS 5000+ & 35.45 & 0.14 & n.d. & 2.0 \\
\hline & $\mathrm{NO}_{3}^{-}$ & ICS 5000+ & 62.00 & 0.08 & n.d. & 2.0 \\
\hline & $\mathrm{SO}_{4}^{2-}$ & ICS 5000+ & 96.06 & 0.10 & n.d. & 2.0 \\
\hline & $\mathrm{Na}^{+}$ & ICS 5000+ & 22.99 & 0.21 & n.d. & 2.0 \\
\hline & $\mathrm{NH}_{4}{ }^{+}$ & ICS 5000+ & 18.04 & 0.28 & n.d. & 2.0 \\
\hline & $\mathrm{K}^{+}$ & ICS 5000+ & 39.10 & 0.13 & n.d. & 2.0 \\
\hline & $\mathrm{Mg}^{2+}$ & ICS 5000+ & 24.31 & 0.21 & n.d. & 2.0 \\
\hline & $\mathrm{Ca}^{2+}$ & ICS 5000+ & 40.08 & 0.13 & n.d. & 2.0 \\
\hline & $\mathrm{Br}^{-}$ & ICS 3000 & 78.90 & 0.005 & 1.584 & 2.3 \\
\hline \multirow{13}{*}{ Sugars } & Inositol & HPLC-PAD & 180.16 & 0.006 & 1.851 & 6.5 \\
\hline & Glycerol & HPLC-PAD & 92.09 & 0.449 & 149.7 & 5.4 \\
\hline & Erythriol & HPLC-PAD & 122.12 & 0.006 & 2.047 & 5.5 \\
\hline & Xylitol & HPLC-PAD & 152.15 & 0.016 & 5.477 & 5.1 \\
\hline & Arabitol & HPLC-PAD & 152.14 & 0.016 & 5.493 & 5.6 \\
\hline & Sorbitol & HPLC-PAD & 182.17 & 0.005 & 1.830 & 8.0 \\
\hline & Mannitol & HPLC-PAD & 182.17 & 0.014 & 4.574 & 6.6 \\
\hline & Threalose & HPLC-PAD & 342.30 & 0.004 & 1.216 & 6.3 \\
\hline & Levoglucosan & HPLC-PAD & 162.14 & 0.012 & 4.112 & 6.7 \\
\hline & Mannosan & HPLC-PAD & 162.14 & 0.015 & 5.139 & 5.3 \\
\hline & Galactosan & HPLC-PAD & 162.14 & 0.009 & 3.037 & 5.8 \\
\hline & Rhamnose & HPLC-PAD & 164.15 & 0.015 & 5.077 & 5.7 \\
\hline & Glucose & HPLC-PAD & 179.15 & 0.014 & 4.665 & 5.6 \\
\hline \multirow{10}{*}{$\begin{array}{l}\text { Organic } \\
\text { acids }\end{array}$} & Formate & ICS 5000+ & 45.02 & 0.22 & n.d. & 10 \\
\hline & Acetate & ICS 5000+ & 59.04 & 0.17 & n.d. & 10 \\
\hline & Oxalate & ICS 3000 & 88.09 & 0.013 & 4.261 & 2.0 \\
\hline & MSA & ICS 3000 & 95.10 & 0.002 & 0.655 & 6.4 \\
\hline & Malic acid & HPLC-MS & 135.08 & 0.009 & 2.961 & 2.0 \\
\hline & Malonic acid & HPLC-MS & 114.06 & 0.022 & 7.248 & 6.4 \\
\hline & Maleic acid & HPLC-MS & 117.10 & 0.010 & 3.444 & 2.4 \\
\hline & Fumaric acid & HPLC-MS & 117.07 & 0.006 & 2.050 & 2.5 \\
\hline & Succinic acid & HPLC-MS & 119.09 & 0.021 & 7.053 & 2.9 \\
\hline & Citraconic acid & HPLC-MS & 131.10 & 0.005 & 1.754 & 1.8 \\
\hline
\end{tabular}




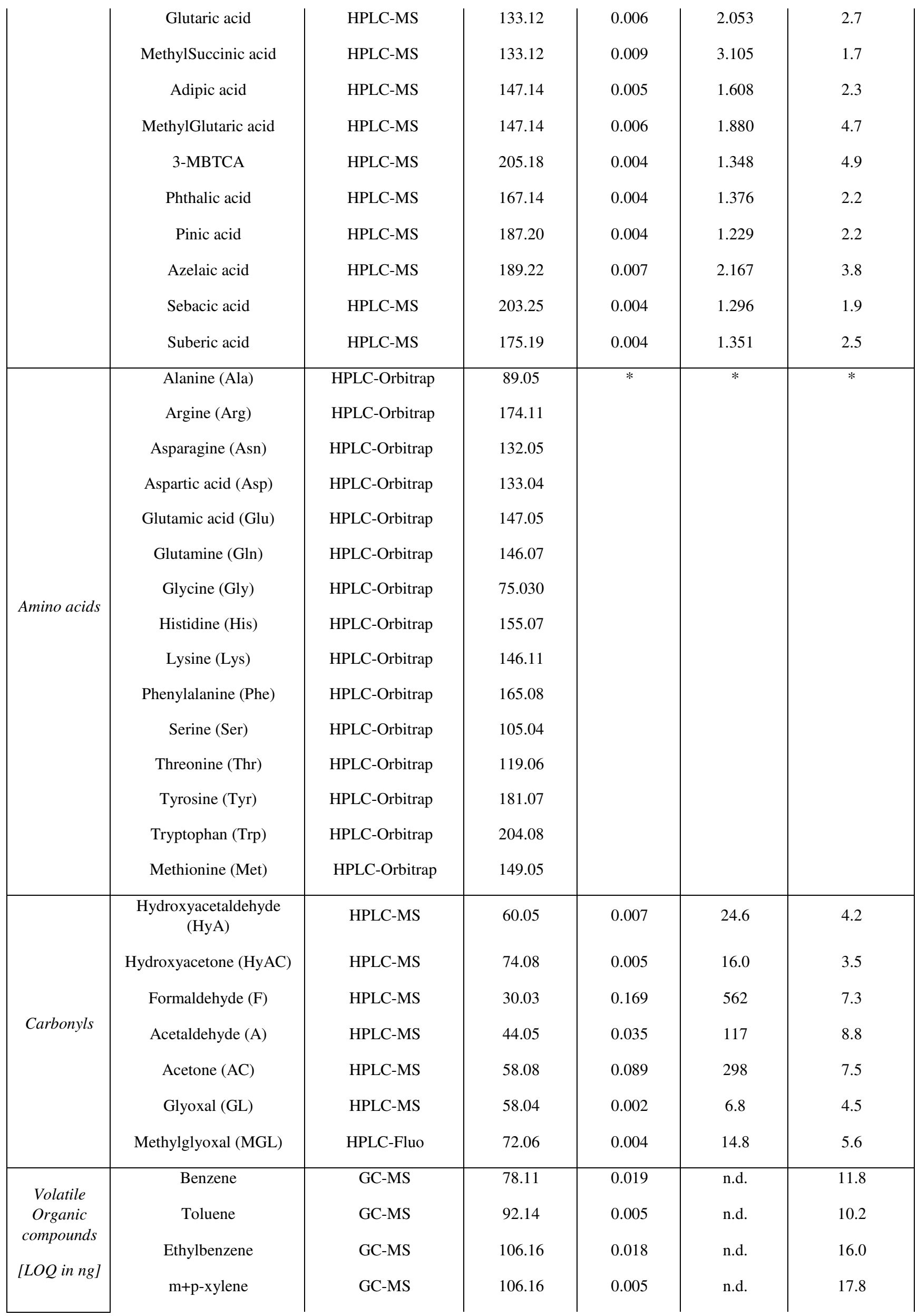




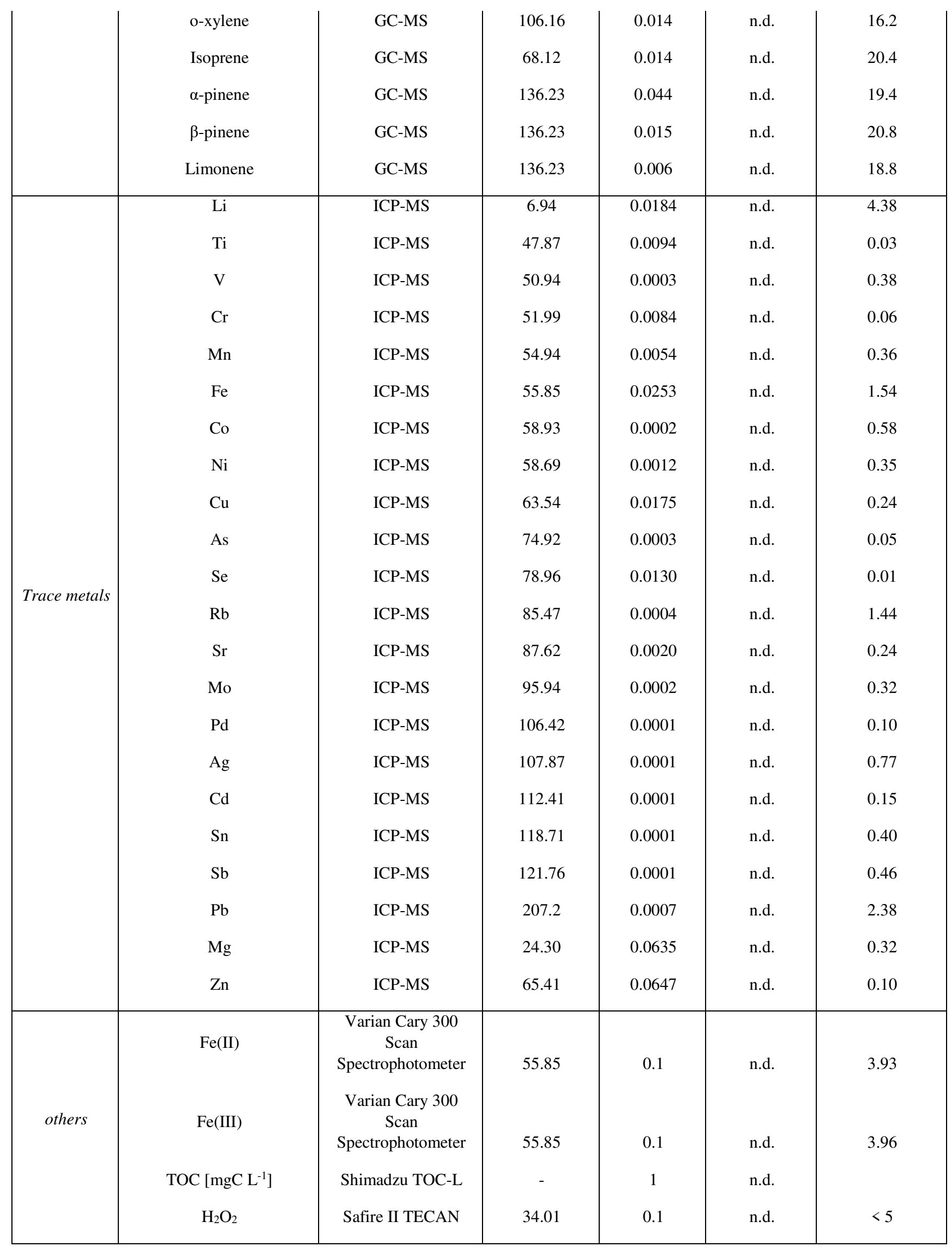

* Standard deviations were calculated for each concentration of each AA in the analytical curves, which reflects the \% of uncertainty (Renard et al., 2021). More details can be found in SI1: Amino Acids, Figure S1 and Table S5. 
Table S3. Average concentrations observed for each cloud event collected during BIO-MAÏDO campaign in March-April 2019.

\begin{tabular}{|c|c|c|c|c|c|c|c|c|c|c|c|c|c|c|c|}
\hline \multirow{2}{*}{$\begin{array}{l}\text { Group of } \\
\text { compounds }\end{array}$} & \multirow{2}{*}{ Compound } & \multicolumn{14}{|c|}{ Cloud event } \\
\hline & & R1 & $\mathbf{R 2}$ & $\mathbf{R 3}$ & R4 & R5 & R6 & $\mathbf{R 7}$ & R8 & R9 & R10A & R10B & R11 & R12 & R13 \\
\hline \multirow{3}{*}{$\begin{array}{c}\text { Sampling } \\
\text { characteristics }\end{array}$} & Date & $\begin{array}{c}14 / 03 / 20 \\
19\end{array}$ & $\begin{array}{c}15 / 03 / 20 \\
19\end{array}$ & $\begin{array}{c}18 / 03 / 20 \\
19\end{array}$ & $\begin{array}{c}19 / 03 / 20 \\
19\end{array}$ & $\begin{array}{c}21 / 03 / 20 \\
19\end{array}$ & $\begin{array}{c}22 / 03 / 20 \\
19\end{array}$ & $\begin{array}{c}26 / 03 / 20 \\
19\end{array}$ & $\begin{array}{c}28 / 03 / 20 \\
19\end{array}$ & $\begin{array}{c}30 / 03 / 20 \\
19\end{array}$ & $\begin{array}{c}01 / 04 / 20 \\
19\end{array}$ & $\begin{array}{c}01 / 04 / 20 \\
19\end{array}$ & $\begin{array}{c}02 / 04 / 20 \\
19\end{array}$ & $\begin{array}{c}03 / 04 / 20 \\
19\end{array}$ & $\begin{array}{c}04 / 04 / 20 \\
19\end{array}$ \\
\hline & $\begin{array}{c}\text { Time (end-start } \\
\text { UTC) }\end{array}$ & $\begin{array}{c}10: 52- \\
11: 45\end{array}$ & $\begin{array}{c}09: 49- \\
12: 15\end{array}$ & $\begin{array}{c}10: 30- \\
12: 04\end{array}$ & $\begin{array}{c}09: 48- \\
10: 31\end{array}$ & $\begin{array}{c}09: 01- \\
12: 22\end{array}$ & $\begin{array}{c}09: 40- \\
12: 00\end{array}$ & $\begin{array}{c}11: 00- \\
15: 15\end{array}$ & $\begin{array}{c}07: 15- \\
12: 31\end{array}$ & $\begin{array}{c}07: 54- \\
14: 30\end{array}$ & $\begin{array}{c}09: 25- \\
11: 02\end{array}$ & $\begin{array}{c}11: 18- \\
14: 30\end{array}$ & $\begin{array}{c}08: 30- \\
14: 00\end{array}$ & $\begin{array}{c}08: 33- \\
11: 35\end{array}$ & $\begin{array}{c}07: 17- \\
11: 26\end{array}$ \\
\hline & $\begin{array}{c}\text { Collected } \\
\text { volume of water } \\
(\mathrm{mL}) \\
\end{array}$ & 62 & 59 & 26 & 58 & 29.5 & 90 & 26 & 138 & 130 & 24.5 & 93.5 & 33 & 7.75 & 54.5 \\
\hline \multirow{2}{*}{$\begin{array}{l}\text { Carboxylic acids } \\
{\left[\mu \mathrm{mol} \mathrm{L} \mathrm{L}^{-1}\right]}\end{array}$} & Acetic & 66.28 & 27.51 & 32.16 & 24.57 & 35.78 & 103.29 & 66.93 & 31.34 & 16.80 & 69.99 & 29.84 & 69.11 & 278.14 & 43.64 \\
\hline & Formic & 22.37 & 40.02 & 34.43 & 16.14 & 19.32 & 15.28 & 30.37 & 9.13 & 9.99 & 16.29 & 12.17 & 31.73 & 43.42 & 19.46 \\
\hline \multirow{6}{*}{$\begin{array}{c}\text { Dicarboxylic } \\
\text { acids } \\
{\left[\mu \mathrm{mol} \mathrm{L} L^{-1}\right]}\end{array}$} & Oxalic & 1.768 & 1.552 & 1.075 & 0.345 & 0.574 & 0.278 & n.d. & 1.559 & 0.299 & n.d. & 0.399 & 0.531 & n.d. & 0.325 \\
\hline & Lactic & 25.86 & 2.107 & 1.340 & 1.166 & 1.980 & 18.37 & n.d. & 4.317 & 0.647 & n.d. & 0.965 & 2.172 & n.d. & 1.017 \\
\hline & Malonic & 0.600 & 0.961 & 0.950 & 0.267 & 0.797 & 0.600 & 1.219 & 1.120 & 0.695 & 2.494 & 1.700 & 1.472 & 0.757 & 1.409 \\
\hline & Succinic & 0.643 & 0.771 & 0.933 & 0.563 & 0.794 & 0.586 & 1.246 & 0.749 & 0.575 & 1.569 & 1.267 & 1.449 & 0.693 & 1.260 \\
\hline & Glutaric & 0.101 & 0.130 & 0.135 & 0.151 & 0.112 & 0.099 & 0.176 & 0.103 & 0.086 & 0.148 & 0.101 & 0.198 & 0.101 & 0.169 \\
\hline & Azelaic & 0.054 & 0.023 & 0.060 & 0.101 & 0.040 & 0.060 & 0.056 & 0.035 & 0.030 & 0.078 & 0.044 & 0.099 & 0.047 & 0.057 \\
\hline \multirow{11}{*}{$\begin{array}{c}\text { Other } \\
\text { dicarboxylic acids } \\
{\left[\mu \mathrm{mol} L^{-1}\right]}\end{array}$} & Maleic & 0.126 & 0.011 & 0.013 & 0.055 & 0.036 & 0.136 & 0.311 & 0.303 & 0.122 & 0.150 & 0.041 & 0.138 & 0.090 & 0.185 \\
\hline & Fumaric & 0.135 & 0.004 & 0.017 & 0.046 & 0.045 & 0.121 & 0.191 & 0.104 & 0.064 & 0.152 & 0.059 & 0.255 & 0.076 & 0.204 \\
\hline & Malic & 0.097 & 0.127 & 0.181 & 0.085 & 0.162 & 0.252 & 0.389 & 0.190 & 0.141 & 0.484 & 0.301 & 0.401 & 0.171 & 0.339 \\
\hline & Citraconic & 0.075 & 0.028 & 0.040 & 0.042 & 0.052 & 0.101 & 0.181 & 0.146 & 0.063 & 0.078 & 0.040 & 0.103 & 0.062 & 0.145 \\
\hline & MethylSuccinic & 0.064 & 0.081 & 0.098 & 0.043 & 0.077 & 0.065 & 0.135 & 0.078 & 0.063 & 0.122 & 0.072 & 0.135 & 0.065 & 0.125 \\
\hline & Adipic & 0.107 & 0.054 & 0.070 & 0.137 & 0.063 & 0.067 & 0.073 & 0.047 & 0.059 & 0.304 & 0.647 & 0.258 & 0.123 & 0.168 \\
\hline & MethylGlutaric & 0.016 & 0.032 & 0.025 & 0.016 & 0.027 & 0.021 & 0.039 & 0.031 & 0.022 & 0.036 & 0.024 & 0.048 & 0.021 & 0.045 \\
\hline & 3-МBТCA & 0.010 & 0.009 & 0.010 & 0.008 & 0.008 & 0.007 & 0.010 & 0.011 & 0.008 & 0.012 & 0.009 & 0.022 & 0.008 & 0.013 \\
\hline & Phthalic & 0.071 & 0.060 & 0.082 & 0.072 & 0.053 & 0.063 & 0.087 & 0.110 & 0.064 & 0.101 & 0.116 & 0.113 & 0.068 & 0.105 \\
\hline & Pinic & 0.000 & 0.005 & 0.006 & 0.000 & 0.003 & 0.003 & 0.010 & 0.000 & 0.000 & 0.000 & 0.006 & 0.000 & 0.000 & 0.005 \\
\hline & Sebacic & 0.009 & 0.005 & 0.007 & 0.015 & 0.005 & 0.006 & 0.007 & 0.006 & 0.018 & 0.164 & 0.029 & 0.169 & 0.017 & 0.078 \\
\hline
\end{tabular}




\begin{tabular}{|c|c|c|c|c|c|c|c|c|c|c|c|c|c|c|c|}
\hline & Suberic & 0.042 & 0.018 & 0.033 & 0.062 & 0.026 & 0.031 & 0.028 & 0.020 & 0.019 & 0.046 & 0.027 & 0.052 & 0.028 & 0.030 \\
\hline \multirow{15}{*}{$\begin{array}{l}\text { Amino Acids } \\
{\left[\text { nmol L } L^{-1}\right]}\end{array}$} & $\begin{array}{l}\text { Alanine } \\
\text { (Ala) }\end{array}$ & 510 & 24 & 356 & 749 & 803 & n.d. & 577 & 509 & 362 & 1810 & 571 & 4869 & n.d. & 1259 \\
\hline & $\begin{array}{l}\text { Arginine } \\
\text { (Arg) }\end{array}$ & 78 & 100 & 180 & 77 & 206 & n.d. & 164 & 177 & 173 & 352 & 203 & 650 & n.d. & 320 \\
\hline & $\begin{array}{l}\text { Asparagine } \\
\text { (Asn) }\end{array}$ & 103 & 26 & 61 & 38 & 71 & n.d. & 79 & 54 & 32 & 236 & 114 & 402 & n.d. & 160 \\
\hline & $\begin{array}{l}\text { Aspartic Acid } \\
\text { (Asp) }\end{array}$ & 178 & 0 & 32 & 33 & 121 & n.d. & 44 & 128 & 93 & 594 & 126 & 1278 & n.d. & 477 \\
\hline & $\begin{array}{c}\text { Glutamine } \\
\text { (Gln) }\end{array}$ & 114 & 49 & 131 & 98 & 147 & n.d. & 114 & 122 & 104 & 519 & 150 & 654 & n.d. & 301 \\
\hline & $\begin{array}{c}\text { Glutamic acid } \\
\text { (Glu) }\end{array}$ & 37 & 52 & 58 & 79 & 80 & n.d. & 66 & 37 & 44 & 191 & 114 & 466 & n.d. & 164 \\
\hline & $\begin{array}{l}\text { Glycine } \\
\text { (Gly) }\end{array}$ & n.d. & n.d. & n.d. & n.d. & n.d. & n.d. & n.d. & 401 & 226 & 676 & 247 & n.d. & n.d. & 485 \\
\hline & $\begin{array}{l}\text { Histidine } \\
\text { (His) }\end{array}$ & 24 & 3 & 20 & 19 & 51 & n.d. & 17 & 61 & 34 & 108 & 73 & 390 & n.d. & 102 \\
\hline & $\begin{array}{c}\text { Lysine } \\
\text { (Lys) }\end{array}$ & 60 & 13 & 53 & 24 & 56 & n.d. & 47 & 71 & 31 & 137 & 70 & 408 & n.d. & 149 \\
\hline & $\begin{array}{c}\text { Methionine } \\
\text { (Met) }\end{array}$ & 30 & 1 & 0 & 41 & 0 & n.d. & 17 & 0 & 0 & 0 & 0 & 0 & n.d. & 0 \\
\hline & $\begin{array}{l}\text { Phenylalanine } \\
\text { (Phe) }\end{array}$ & 163 & 92 & 149 & 114 & 166 & n.d. & 123 & 143 & 107 & 130 & 156 & 421 & n.d. & 224 \\
\hline & $\begin{array}{c}\text { Serine } \\
(\text { Ser })\end{array}$ & 1216 & 60 & 241 & 357 & 692 & n.d. & 168 & 976 & 386 & 3023 & 1161 & n.d. & n.d. & 1914 \\
\hline & $\begin{array}{l}\text { Threonine } \\
\text { (Thr) }\end{array}$ & 396 & 63 & 108 & 133 & 139 & n.d. & 112 & 194 & 84 & 502 & 133 & 1021 & n.d. & 294 \\
\hline & $\begin{array}{l}\text { Tryptophan } \\
\text { (Trp) }\end{array}$ & 6 & 0 & 1 & 22 & 3 & n.d. & 1 & 0 & 0 & 0 & 3 & 28 & n.d. & 2 \\
\hline & $\begin{array}{c}\text { Tyrosine } \\
\text { (Tyr) }\end{array}$ & 513 & 314 & 567 & 61 & 501 & n.d. & 408 & 214 & 89 & 277 & 196 & 1017 & n.d. & 378 \\
\hline \multirow{3}{*}{$\begin{array}{l}\text { Saturated } \\
\text { carbonyls } \\
{\left[\mu m o l L^{-1}\right]}\end{array}$} & $\begin{array}{l}\text { Formaldehyde } \\
(\mathrm{F})\end{array}$ & 1.381 & 0.761 & n.d. & 1.073 & 2.135 & 0.633 & 0.968 & 2.942 & 0.961 & n.d. & 0.912 & 1.688 & n.d. & 1.943 \\
\hline & $\begin{array}{l}\text { Acetaldehyde } \\
\text { (A) }\end{array}$ & 3.205 & 0.084 & n.d. & 0.216 & 0.249 & 0.242 & 0.109 & 0.323 & 0.155 & n.d. & 0.298 & 0.146 & n.d. & 0.207 \\
\hline & Acetone (AC) & 0.284 & 0.267 & n.d. & 0.367 & 0.265 & 0.191 & 0.174 & 0.178 & 0.178 & n.d. & 0.560 & 0.355 & n.d. & 0.372 \\
\hline \multirow{2}{*}{$\begin{array}{c}\text { Hydroxy carbonyl } \\
\text { compounds } \\
{\left[\mu \mathrm{mol} L^{-1}\right]}\end{array}$} & $\begin{array}{c}\text { Hydroxy } \\
\text { acetaldehyde } \\
\text { (HyA) }\end{array}$ & 0.414 & 0.039 & n.d. & 0.188 & 0.589 & 0.230 & 0.493 & 1.823 & 0.485 & n.d. & 0.244 & 0.707 & n.d. & 0.699 \\
\hline & $\begin{array}{c}\text { Hydroxy } \\
\text { acetone (HyAC) }\end{array}$ & 0.637 & 0.115 & n.d. & 0.493 & 0.275 & 0.076 & 0.072 & 0.364 & 0.102 & n.d. & 0.218 & 0.093 & n.d. & 0.139 \\
\hline \multirow{2}{*}{$\begin{array}{l}\text { Dicarbonyl } \\
\text { compounds } \\
{\left[\mu \mathrm{mol} \mathrm{L} L^{-1}\right]}\end{array}$} & Glyoxal (GL) & 0.100 & 0.020 & n.d. & 0.025 & 0.138 & 0.198 & 1.990 & 0.883 & 0.323 & n.d. & 0.085 & 0.174 & n.d. & 0.165 \\
\hline & $\begin{array}{l}\text { Methylglyoxal } \\
\text { (MGL) }\end{array}$ & 0.059 & 0.120 & n.d. & 0.208 & 0.138 & 0.080 & 0.275 & 0.516 & 0.094 & n.d. & 0.165 & 0.126 & n.d. & 0.142 \\
\hline
\end{tabular}




\begin{tabular}{|c|c|c|c|c|c|c|c|c|c|c|c|c|c|c|c|}
\hline \multirow{10}{*}{$\begin{array}{c}\text { Ions } \\
{\left[\mu \mathrm{mol} \mathrm{L} L^{-1}\right]}\end{array}$} & $\mathrm{Na}^{+}$ & 245.51 & 556.27 & 316.25 & 161.47 & 259.90 & 225.84 & 1414.02 & 221.83 & 184.54 & 647.97 & 253.60 & 682.93 & 1357.16 & 333.48 \\
\hline & $\mathrm{NH}_{4}^{+}$ & 91.82 & 131.14 & 155.04 & 31.34 & 88.38 & 77.00 & 154.17 & 126.38 & 81.08 & 145.75 & 130.65 & 184.16 & 185.39 & 151.18 \\
\hline & $\mathrm{K}^{+}$ & 38.61 & 12.21 & 17.12 & 23.95 & 16.13 & 20.19 & 42.96 & 12.35 & 12.05 & 41.41 & 14.87 & 76.21 & 200.76 & 33.44 \\
\hline & $\mathrm{Mg}^{2+}$ & 53.49 & 105.33 & 95.26 & 39.25 & 45.18 & 48.06 & 237.71 & 40.54 & 27.40 & 96.74 & 39.61 & 85.20 & 170.20 & 51.20 \\
\hline & $\mathrm{Ca}^{2+}$ & 46.29 & 47.67 & 88.18 & 65.83 & 54.38 & 74.14 & 123.07 & 44.08 & 41.02 & 128.78 & 45.66 & 133.79 & 282.08 & 91.95 \\
\hline & $\mathrm{Cl}^{-}$ & 172.99 & 530.72 & 214.24 & 90.01 & 213.75 & 183.38 & 992.65 & 189.95 & 174.96 & 527.35 & 224.03 & 995.92 & 1289.09 & 281.06 \\
\hline & $\mathrm{NO}_{3}^{-}$ & 62.52 & 166.71 & 212.39 & 84.94 & 141.71 & 89.77 & 403.29 & 163.41 & 107.76 & 366.08 & 173.86 & 416.89 & 688.87 & 281.67 \\
\hline & $\mathrm{SO}_{4}{ }^{2-}$ & 80.38 & 114.94 & 219.21 & 103.29 & 98.89 & 97.52 & 135.66 & 113.14 & 60.92 & 147.27 & 88.35 & 137.23 & 195.90 & 65.88 \\
\hline & MSA & 1.342 & 0.805 & 0.612 & 0.240 & 0.407 & 0.172 & n.d. & 0.406 & 0.158 & n.d. & 0.351 & 0.691 & n.d. & 0.446 \\
\hline & $\mathrm{Br}^{-}$ & 0.157 & 0.416 & 0.156 & 0.094 & 0.152 & 0.186 & n.d. & 0.113 & 0.131 & n.d. & 0.166 & 0.368 & n.d. & 0.158 \\
\hline \multirow{13}{*}{$\begin{array}{c}\text { Sugars } \\
{\left[\mu \mathrm{mol} \mathrm{L} L^{-1}\right]}\end{array}$} & Inositol & 0.012 & 0.032 & 0.066 & 0.015 & 0.017 & 0.011 & n.d. & 0.035 & 0.015 & n.d. & 0.014 & 0.174 & n.d. & 0.119 \\
\hline & Glycerol & 11.343 & 2.581 & 5.201 & 3.868 & 2.190 & n.d. & n.d. & 2.237 & 7.319 & n.d. & n.d. & 3.895 & n.d. & 3.570 \\
\hline & Erythriol & 0.001 & 0.241 & 0.476 & 0.470 & 0.291 & 0.001 & n.d. & 0.280 & 0.343 & n.d. & 0.001 & 0.840 & n.d. & 0.828 \\
\hline & Xylitol & 0.003 & 0.003 & 0.003 & 0.003 & 0.003 & 0.003 & n.d. & 0.003 & 0.003 & n.d. & 0.003 & 0.003 & n.d. & 0.003 \\
\hline & Arabitol & 0.351 & 0.127 & 0.384 & 0.588 & 0.462 & 0.432 & n.d. & 0.261 & 0.290 & n.d. & 0.659 & 0.951 & n.d. & 0.780 \\
\hline & Sorbitol & 1.140 & 2.719 & 5.156 & 5.798 & 4.735 & 3.656 & n.d. & 2.502 & 6.013 & n.d. & 2.314 & 23.855 & n.d. & 9.267 \\
\hline & Mannitol & 0.919 & 0.173 & 0.647 & 0.367 & 0.367 & 1.164 & n.d. & 0.411 & 0.400 & n.d. & 0.743 & 2.282 & n.d. & 1.099 \\
\hline & Threalose & 0.001 & 0.036 & 0.076 & 0.176 & 0.075 & 0.072 & n.d. & 0.081 & 0.089 & n.d. & 0.184 & 0.346 & n.d. & 0.203 \\
\hline & Levoglucosan & 0.153 & 0.262 & 0.248 & 0.110 & 0.127 & 0.191 & n.d. & 0.182 & 0.124 & n.d. & 0.151 & 0.167 & n.d. & 0.277 \\
\hline & Mannosan & 0.003 & 0.003 & 0.003 & 0.068 & 0.003 & 0.003 & n.d. & 0.003 & 0.003 & n.d. & 0.003 & 0.003 & n.d. & 0.003 \\
\hline & Galactosan & 0.430 & 0.002 & 0.002 & 0.096 & 0.200 & 0.002 & n.d. & 0.162 & 0.111 & n.d. & 0.192 & 0.210 & n.d. & 0.195 \\
\hline & Rhamnose & 0.003 & 0.003 & 0.003 & 0.003 & 0.003 & 0.003 & n.d. & 0.003 & 0.003 & n.d. & 0.003 & 0.003 & n.d. & 0.003 \\
\hline & Glucose & 1.742 & 0.565 & 0.959 & 3.968 & 1.547 & 1.063 & n.d. & 0.680 & 0.953 & n.d. & 2.773 & 5.328 & n.d. & 2.915 \\
\hline \multirow{4}{*}{$\begin{array}{c}\text { Metals } \\
{\left[\mu m o l L^{-1}\right]}\end{array}$} & $\mathrm{Li}$ & 0.003 & n.d. & n.d. & n.d. & n.d. & n.d. & n.d. & n.d. & n.d. & n.d. & n.d. & n.d. & n.d. & n.d. \\
\hline & $\mathrm{Ti}$ & n.d. & 0.000 & n.d. & 0.027 & n.d. & n.d. & n.d. & 0.004 & n.d. & 0.005 & 0.001 & 0.002 & 0.001 & 0.001 \\
\hline & V & 0.003 & 0.004 & n.d. & 0.003 & 0.003 & n.d. & n.d. & 0.022 & n.d. & 0.033 & 0.023 & 0.017 & 0.006 & 0.010 \\
\hline & $\mathrm{Cr}$ & 0.001 & n.d. & n.d. & 0.001 & n.d. & n.d. & n.d. & 0.001 & n.d. & 0.001 & n.d. & 0.001 & 0.004 & 0.000 \\
\hline
\end{tabular}




\begin{tabular}{|c|c|c|c|c|c|c|c|c|c|c|c|c|c|c|c|}
\hline & $\mathrm{Mn}$ & 0.070 & 0.094 & n.d. & 0.072 & 0.019 & n.d. & n.d. & 0.032 & n.d. & 0.047 & 0.016 & 0.064 & 0.064 & 0.057 \\
\hline & $\mathrm{Fe}$ & n.d. & n.d. & n.d. & n.d. & n.d. & n.d. & n.d. & 0.049 & n.d. & 0.018 & 0.006 & 0.004 & 0.031 & \\
\hline & $\mathrm{Co}$ & 0.001 & 0.001 & n.d. & 0.001 & 0.000 & n.d. & n.d. & 0.001 & n.d. & 0.001 & 0.000 & 0.001 & 0.001 & 0.001 \\
\hline & $\mathrm{Ni}$ & 0.045 & 0.006 & n.d. & 0.009 & 0.002 & n.d. & n.d. & 0.016 & n.d. & 0.016 & 0.008 & 0.015 & 0.022 & 0.009 \\
\hline & $\mathrm{Cu}$ & 0.080 & 0.021 & n.d. & 0.065 & 0.010 & n.d. & n.d. & 0.021 & n.d. & 0.033 & 0.026 & 0.032 & 0.050 & 0.020 \\
\hline & As & 0.000 & 0.000 & n.d. & 0.000 & n.d. & n.d. & n.d. & 0.000 & n.d. & 0.000 & 0.000 & 0.000 & 0.000 & 0.000 \\
\hline & $\mathrm{Se}$ & 0.000 & 0.001 & n.d. & 0.000 & n.d. & n.d. & n.d. & n.d. & n.d. & n.d. & 0.000 & 0.000 & 0.000 & 0.000 \\
\hline & $\mathrm{Rb}$ & 0.003 & 0.002 & n.d. & 0.004 & 0.002 & n.d. & n.d. & 0.004 & n.d. & 0.008 & 0.004 & 0.009 & 0.008 & 0.004 \\
\hline & $\mathrm{Sr}$ & 0.014 & 0.023 & n.d. & 0.014 & 0.008 & n.d. & n.d. & 0.018 & n.d. & 0.050 & 0.017 & 0.046 & 0.040 & 0.025 \\
\hline & Mo & 0.000 & 0.002 & n.d. & 0.000 & 0.000 & n.d. & n.d. & 0.000 & n.d. & 0.000 & 0.000 & 0.000 & 0.000 & 0.000 \\
\hline & $\mathrm{Pd}$ & 0.000 & 0.000 & n.d. & 0.000 & n.d. & n.d. & n.d. & 0.000 & n.d. & 0.001 & 0.000 & 0.000 & 0.000 & 0.000 \\
\hline & $\mathrm{Ag}$ & n.d. & 0.018 & n.d. & 0.000 & 0.003 & n.d. & n.d. & 0.002 & n.d. & n.d. & 0.000 & 0.000 & 0.000 & 0.000 \\
\hline & $\mathrm{Cd}$ & 0.001 & n.d. & n.d. & 0.000 & n.d. & n.d. & n.d. & 0.001 & n.d. & 0.001 & 0.000 & 0.000 & 0.001 & 0.000 \\
\hline & $\mathrm{Sn}$ & 0.000 & n.d. & n.d. & 0.000 & n.d. & n.d. & n.d. & 0.000 & n.d. & 0.000 & n.d. & 0.000 & 0.000 & n.d. \\
\hline & $\mathrm{Sb}$ & 0.001 & 0.000 & n.d. & 0.000 & n.d. & n.d. & n.d. & 0.001 & n.d. & 0.001 & 0.000 & 0.001 & 0.002 & 0.000 \\
\hline & $\mathrm{Pb}$ & 0.000 & & n.d. & 0.000 & 0.000 & n.d. & n.d. & 0.000 & n.d. & 0.000 & 0.000 & 0.000 & 0.000 & n.d. \\
\hline & $\mathrm{Mg}$ & 6.954 & 13.803 & n.d. & 4.653 & 3.321 & n.d. & n.d. & 6.361 & n.d. & 13.521 & 4.834 & 14.049 & 14.115 & 7.873 \\
\hline & $\mathrm{Zn}$ & 0.341 & 0.098 & n.d. & 0.075 & 0.240 & n.d. & n.d. & 0.842 & n.d. & 1.438 & 0.749 & 1.272 & 1.851 & 0.633 \\
\hline & others & 0.011 & 0.024 & n.d. & 0.034 & 0.006 & n.d. & n.d. & 0.014 & n.d. & 0.017 & 0.007 & 0.016 & 0.018 & 0.008 \\
\hline \multirow{8}{*}{$\begin{array}{c}V O C \\
{\left[n g m L^{-1}\right]}\end{array}$} & Benzene & n.d. & n.d. & n.d. & n.d. & 0.78 & n.d. & n.d. & 0.27 & 0.14 & n.d. & 0.15 & 0.05 & n.d. & n.d. \\
\hline & Toluene & n.d. & 0.12 & n.d. & n.d. & 0.06 & 0.08 & n.d. & 0.10 & 0.21 & n.d. & 0.05 & 0.08 & n.d. & 0.11 \\
\hline & Ethylbenzene & n.d. & 0.08 & n.d. & n.d. & 0.04 & 0.05 & n.d. & 0.07 & 0.15 & n.d. & 0.03 & 0.05 & n.d. & 0.08 \\
\hline & m+p-xylene & 0.03 & 0.08 & n.d. & n.d. & 0.03 & 0.11 & 0.02 & 0.05 & 0.03 & n.d. & 0.04 & 0.04 & n.d. & 0.04 \\
\hline & o-xylene & 0.02 & 0.06 & n.d. & n.d. & 0.03 & 0.09 & 0.01 & 0.03 & 0.02 & n.d. & 0.03 & 0.02 & n.d. & 0.03 \\
\hline & Isoprene & 2.43 & 1.26 & n.d. & n.d. & 1.34 & n.d. & 2.45 & 2.77 & 2.09 & n.d. & 3.34 & 1.59 & n.d. & 3.74 \\
\hline & $\alpha$-pinene & 0.15 & 0.28 & n.d. & n.d. & 0.02 & 0.05 & 0.19 & 0.07 & 9.73 & n.d. & 0.27 & 0.01 & n.d. & 0.10 \\
\hline & $\beta$-pinene & 0.11 & 0.20 & n.d. & n.d. & n.d. & n.d. & 0.14 & n.d. & 5.43 & n.d. & 0.18 & n.d. & n.d. & 0.03 \\
\hline
\end{tabular}




\begin{tabular}{|c|c|c|c|c|c|c|c|c|c|c|c|c|c|c|c|}
\hline & Limonene & 0.50 & 0.49 & n.d. & n.d. & 0.12 & 0.07 & 0.46 & 0.07 & 5.23 & n.d. & 0.31 & 0.07 & n.d. & 0.27 \\
\hline & 135-TMB & 0.015 & 0.018 & n.d. & n.d. & 0.284 & n.d. & n.d. & 0.003 & 0.008 & n.d. & 0.009 & 0.0001 & n.d. & 0.022 \\
\hline & 124-TMB & 0.042 & 0.021 & n.d. & n.d. & 0.018 & 0.011 & 0.016 & 0.015 & 0.002 & n.d. & 0.030 & 0.016 & n.d. & 0.027 \\
\hline & 123-TMB & 0.005 & 0.003 & n.d. & n.d. & 0.004 & 0.001 & 0.004 & 0.001 & n.d. & n.d. & 0.004 & 0.001 & n.d. & 0.003 \\
\hline \multirow{3}{*}{$\begin{array}{l}\text { Oxidants } \\
{\left[\mu \mathrm{mol} L^{-1}\right]}\end{array}$} & $\mathrm{Fe}(\mathrm{II})$ & 0.317 & 0.266 & 0.609 & 0.300 & 0.497 & 0.559 & 0.662 & 0.382 & 0.292 & 0.488 & 0.264 & 0.363 & 0.798 & 0.294 \\
\hline & $\mathrm{Fe}(\mathrm{III})$ & 0.450 & 0.591 & 0.596 & 0.479 & 0.809 & 0.382 & 0.032 & 0.641 & 0.422 & 0.489 & 0.430 & 0.493 & 0.093 & 0.426 \\
\hline & $\mathrm{H}_{2} \mathrm{O}_{2}$ & 0.28 & 1.84 & 8.79 & 1.28 & 0.71 & n.d. & 0.25 & 0.04 & 0.43 & 0.64 & 2.46 & 4.05 & n.d. & 2.48 \\
\hline \multirow{3}{*}[mgCL^{-1}]{} & $\mathrm{TC}$ & 36.51 & 9.19 & 80.58 & 11.33 & 23.44 & 52.98 & n.d, & 9.33 & 9.27 & 26.83 & 18.12 & 20.02 & 65.88 & 17.67 \\
\hline & IC & 2.41 & 1.13 & 21.5 & 1.22 & 3.39 & 6.90 & n.d. & 1.46 & 3.45 & 1.45 & 1.15 & 1.09 & 3.87 & 1.12 \\
\hline & TOC & 34.1 & 8.06 & 59.1 & 10.1 & 20.1 & 46.1 & n.d. & 7.87 & 5.82 & 25.4 & 17.0 & 19.0 & 62.0 & 16.5 \\
\hline \multirow{4}{*}{$\begin{array}{l}\text { Other parameters } \\
\text { (Microphysical } \\
\text { properties, etc.) }\end{array}$} & $\begin{array}{c}\mathrm{LWC} \\
{\left[\mathrm{g} \mathrm{m}^{-3}\right]}\end{array}$ & 0.047 & 0.090 & 0.023 & 0.028 & 0.143 & 0.138 & 0.068 & 0.126 & 0.088 & 0.081 & 0.073 & 0.054 & 0.038 & 0.086 \\
\hline & $\operatorname{Deff}(\mu \mathrm{m})$ & 14.7 & 12.1 & 13.3 & 15.8 & 15.2 & 16.1 & 14.6 & 12.7 & 15.3 & 11.5 & 12.6 & 14.1 & 11.6 & 12.7 \\
\hline & $\begin{array}{c}\text { Temperature } \\
\left({ }^{\circ} \mathrm{C}\right)\end{array}$ & 15.1 & n.d. & 18.2 & 17.0 & 17.0 & 17.0 & n.d. & 17.5 & 17.2 & 17.6 & 16.6 & 17.2 & n.d. & 17.2 \\
\hline & $\mathrm{pH}$ & 4.70 & 5.00 & 5.50 & 5.50 & 5.30 & 5.50 & 5.15 & 5.55 & 5.15 & 5.00 & 5.50 & 5.15 & 5.30 & 5.00 \\
\hline
\end{tabular}

n.d.: not detected. 


\section{Cloud collector description}

The cloud sampler used in this study is a newly designed collector for sampling cloud droplets suitable for cloud chemical and microbiological analysis. It is based on the same impaction procedure as the CWS sampler (Kruisz et al., 1993) but using 3 vertical impaction plates instead of one. CWS samplers are commonly used by our team for collecting cloud water at the PUY station. The inlet width and the distance between the inlet and impaction plate is conserved to keep the same cut-off diameter around $7 \mu \mathrm{m}$ as estimated by Kruisz et al. (1993). This impactor is made in aluminium that is easily sterilisable for biological analysis. It is composed of 3 parts (inlet, impaction plates, collection funnel) that are installed on a metallic box where a ventilator fan is installed, before the sampling. These parts are sterilized before each sampling. The sampler runs with a $12 \mathrm{~V}$ battery, and the total mass of the system is around $8 \mathrm{~kg}$, allowing to install it at the top of the $10 \mathrm{~m}$ mast. Those developments are detailed in a paper that will be submitted soon (Vaïtilingom et al., in prep, 2021).

\section{Sample conservation}

During the campaign period, the sample were filtered and stored under frozen or refrigerated conditions based on storage procedures (as the one performed for cloud waters sampled at the PUY station, regularly).

Once the field campaign had finished on 4 April 2019, cloud samples were immediately expedited to France (mainland, Clermont-Ferrand, and Grenoble laboratories) following the storage conditions for each type of analysis, under frozen or refrigerated conditions. This was performed by the transportation and logistics unit of the CNRS (Ulisse). Targeted chemical analyses were performed approximately 10 days after the arrival of the samples at the laboratories.

\section{Chemical analyses}

\section{Trace metals}

Trace metals are quantified using ICP-MS Agilent 7500. Before the injection into the instrument, aliquots of cloud water samples are directly transferred in $6 \mathrm{~mL}$ ICP-MS polystyrene vials previously conditioned. Samples are diluted with $4500 \mu \mathrm{L}$ of distilled $\mathrm{HNO}_{3} 1 \mathrm{M}$ in MilliQ water. Finally, samples are injected into the plasma using a quartz introduction system (Micromist Nebulizerand a Scott-type spray chamber), and their analyses are performed in plasma robust mode (1550 W). Multi-elements standards ( 1 and $10 \mathrm{ng} \mathrm{g}^{-1}$ are used for the signal calibration, previously prepared by gravimetric dilution of 10 $\mu \mathrm{g} \mathrm{mL} \mathrm{L}^{-1}$ of certified solutions traceable to NIST (National Institute of Standards and Technology) (Inorganic Ventures). Concentrations values in $\mu \mathrm{g} \mathrm{g}^{-1}$ are converted in $\mu \mathrm{g} \mathrm{L}^{-1}$ considering the solution density $\left(1.01 \mathrm{~kg} \mathrm{~L}^{-1}\right)$. Limit of quantification (LOQ) is reported in Table S2, and it is calculated from five independent measurements of the signal acquired on the MilliQ$\mathrm{HNO}_{3}$ redistilled. On average the LQ ranges from 0.01 to $4.2 \mu \mathrm{g} \mathrm{L}^{-1}$ for more concentrated elements $(\mathrm{Mg}, \mathrm{Ti}, \mathrm{Fe}, \mathrm{Cu}, \mathrm{Zn}, \mathrm{Sr})$ to 1 to $60 \mathrm{ng} \mathrm{L}^{-1}$ for less concentrated elements (V, Mn, Co, As, Rb, Cd, Sb, W, Tl, Pb, U). Li, Be, Sc, Cr, Ga, Se, Nb, Pd, Ag, Mo, In, Sn, Te, Ta, Pt, and Bi are measured for each sample, but their concentrations are below the LQ. The experimental blank is executed by spreading Milli-Q water on the cloud water impactor and collecting it in a clean Falcon ${ }^{\circledR}$ tube (the same used for samples). Calibration standards $(0,1$, and $10 \mathrm{ppb})$ were analysed before and after the samples and every three samples. The replicates were used to calculate the uncertainty of the signal.

\section{$\mathrm{H}_{2} \mathrm{O}_{2}$}

Hydrogen peroxide concentration is measured by UV-Visible spectroscopy using p-hydroxyphenylacetic acid (HPAA, purity $>98 \%$ ) and horseradish peroxidase (POD) (solid containing 150-200 units per milligram). The formation of the dimer of 
HPAA is correlated with the concentration of hydrogen peroxide and is detected by fluorescence. Fluorescence readings (Safire II TECANC; $\lambda_{\mathrm{exc}}=320 \mathrm{~nm}, \lambda_{\mathrm{em}}=390 \mathrm{~nm}$ ) are made in a dark 96 well plate format (Wirgot et al., 2017). Analytical uncertainty is determined to be below $5 \%$ and the limit of quantification is $0.1 \mu \mathrm{mol} \mathrm{L}-1$.

\section{Iron and Total organic carbon (TOC)}

$\mathrm{Fe}$ (II) and Fe (III) concentrations are determined by the spectrophotometric method by complexation with ferrozine (purity > $97 \%$ ), as described by Stookey et al.(1970) Ascorbic acid (purity reagent grade) is used as the reducing agent to determine total iron. The well-known molar absorption coefficient of the complex between ferrozine and Fe (II) $\left(\varepsilon_{562 \mathrm{~nm}}=27900 \mathrm{M}^{-1} \mathrm{~cm}^{-}\right.$

${ }^{1}$ ) was used to calculate the Fe (II) concentration. The complex absorption is measured with a Varian Cary 300 Scan Spectrophotometer at $562 \mathrm{~nm}$. It has been previously demonstrated that filtration does not modify the soluble iron quantification in natural cloud water samples. The limit of quantification is of the order of $0.1 \mu \mathrm{mol} \mathrm{L}^{-1}$ and the error for this concentration range is $15 \%$. TC, IC, and TOC are measured with Shimadzu TOC-L analyser. Calibration was performed using $\mathrm{KHCO}_{3} / \mathrm{K}_{2} \mathrm{CO}_{3}$ mixture for IC and potassium hydrogen phthalate for TC. The limit of detection is of the order of $1 \mathrm{mg} \mathrm{L}^{-1}$ and the precision of $0.1 \mathrm{mg} \mathrm{L}^{-1}$.

\section{Inorganic and organic ions}

Ion chromatography (IC) analysis is performed employing an ICS 5000+ equipped with an IonPac GC11 (guard-column $4 \times$ $50 \mathrm{~mm}$ ) and an IonPac AS18 (analytical column $5 \times 250 \mathrm{~mm}$ ) for anions and an IonPac GC16 (guard-column $4 \times 50 \mathrm{~mm}$ ) and

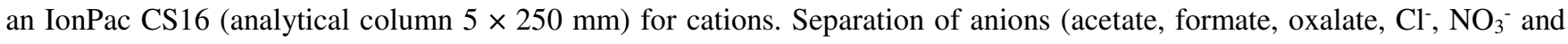
$\left.\mathrm{SO}_{4}^{2-}\right)$ is achieved with a gradient of $\mathrm{KOH}(10-19.5 \mathrm{mM})$, reported in Bianco (2016), while separation of cations $\left(\mathrm{Na}^{+}, \mathrm{NH}_{4}^{+}\right.$, $\mathrm{Mg}^{2+}, \mathrm{Ca}^{2+}, \mathrm{K}^{+}$) is achieved with isocratic elution with methanesulfonic acid (MSA). The injection volume is $125 \mu \mathrm{L}$ and both columns are at $40{ }^{\circ} \mathrm{C}$, with a flow of $0.25 \mathrm{~mL} \mathrm{~min}^{-1}$ and $0.36 \mathrm{~mL} \mathrm{~min}^{-1}$ for anions and cations, respectively. The suppressor used for anions detection is ASRS_2mm and for cations detection CSRS_4mm. Polypropylene vials and septum are rinsed three times with MilliQ water and let dry in a fume hood, to avoid contamination and dilution. Calibration is performed by the analysis of multielement standards for ion chromatography of anions, short-chain carboxylic acids, and cations, purchased from Sigma Aldrich (dilution with MilliQ water). Two replicates are analysed for each sample, with dilution 1/2, and the uncertainty on the signal is below $2 \%$. Due to the high signal obtained with the $1 / 2$ dilution, samples R3, R5, R6, R7, R11, and R12 are analysed also with dilution $1 / 10$.

Cloud water samples analysis of soluble ions is done using Dionex Dual ICS-3000 ion chromatography system in the class100 clean room at the IGE Laboratory. Chemical analysis of cations $\left(\mathrm{Na}^{+}, \mathrm{NH}_{4}^{+}, \mathrm{K}^{+}, \mathrm{Mg}^{2+}, \mathrm{Ca}^{2+}\right)$ is performed using CG16 and CS16 cations separator column and a CSRS-300 conductivity suppressor (Dionex) and isocratic 27 mmol L-1 methanesulfonic acid as eluent. Anions $\left(\mathrm{Cl}^{-}, \mathrm{NO}_{3}{ }^{-}, \mathrm{SO}_{4}{ }^{2-}, \mathrm{Br}^{-}, \mathrm{MSA}\right.$, oxalate, acetate, formate) analysis is performed using AG11-HC and AS11-HC columns and ASRS-300 suppressor, applying a gradient elution $\left(0.3-30 \mathrm{mmol} \mathrm{L}^{-1} \mathrm{KOH}\right)$.

Analytical uncertainty is determined as the relative standard deviation of 27 replicates of quality control standard (at an intermediate concentration of samples), prepared independently from a refrigerated stock solution, and run on 3 different days with a daily calibration.

\section{Anhydrosugars, sugar alcohols, primary sugars}

Cloud water analyses for anhydrosugars, sugar alcohols, and primary sugars, are achieved using an HPLC with Pulsed Amperometric Detection. We use a Thermo-Fisher ICS 5000+ HPLC equipped with a 4 mm diameter Metrosep Carb $2 \times 150$ $\mathrm{mm}$ column and $50 \mathrm{~mm}$ pre-column. The analytical run is isocratic with $15 \%$ of an eluent of sodium hydroxide $\left(200 \mathrm{mmol} \mathrm{L}^{-}\right.$ 
${ }^{1}$ ) with sodium acetate $(4 \mathrm{~m} \mu \mathrm{mol} \mathrm{L}-1)$, and $85 \%$ water, at $1 \mathrm{~mL} \mathrm{~min}^{-1}$. The extraction of samples was performed for $20 \mathrm{~min}$ in a vortex. This analytical technique enables the detection of anhydrous saccharides (levoglucosan, mannosan, galactosan), polyols (arabitol, sorbitol, mannitol, erythritol, xylitol), trehalose, glycerol, and glucose (Samaké et al., 2019).

Analytical uncertainty is determined as the largest value for each compound between the relative standard deviation of 36 replicates of standards covering the range of samples concentrations (prepared daily from refrigerated stock solutions, and run on two different days), and the relative standard deviation of 3 atmospheric filter samples run in triplicates for EMEP 2018 intercomparison.

\section{Organic acids}

A large suite of organic acids is analysed by HPLC-MS (GP40 Dionex with an LCQ-FLEET Thermos-Fisher ion trap), with negative ion mode electrospray ionization. The separation column is a Synergi $4 \mu \mathrm{m}$ Fusion $-\mathrm{RP} 80 \mathrm{~A}(250 \times 3 \mathrm{~mm}$ ID, $4 \mu \mathrm{m}$ particle size, from Phenomenex). An elution gradient is optimized for the separation of the compounds, with a binary solvent gradient consisting of $0.1 \%$ formic acid in acetonitrile (solvent $\mathrm{A}$ ) and $0.1 \%$ aqueous formic acid (solvent $\mathrm{B}$ ) in various proportions during the 40 -minute analytical run. The column temperature is maintained to $30{ }^{\circ} \mathrm{C}$. The eluent flow rate is 0.5

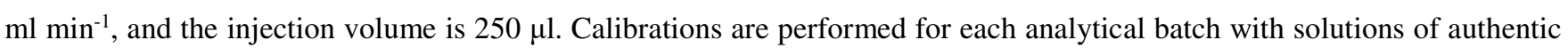
standards. All standards and samples are spiked with internal standards (phthalic-3,4,5,6- $\mathrm{d}^{4}$ acid and succinic-2,2,3,3-d $\mathrm{d}^{4}$ acid). The final cloud water concentration is corrected with the concentrations of internal standards and with the procedural blanks, taking also into account the extraction efficiency varying between 76-116\% (depending on the acid).

Analytical uncertainty is determined as the relative standard deviation of 9 replicates of standard solution (prepared every day from a refrigerated stock solution, at an intermediate concentration of samples), run on 3 different days with daily calibration.

\section{Carbonyls}

Carbonyls are analyzed after derivatization by fluorescent dansylacetamidooxyamine (DNSAOA) (Houdier et al., 2000). Derivatization reactions are performed in the presence of anilinium chloride ( $\mathrm{AnCl})$ as a catalyst (Houdier et al., 2018) to quicken derivatization reactions. Adducts (oximes) that form upon reaction are separated by HPLC. Fluorescence detection and mass spectrometry (MS) detection are used in series for a more reliable identification/quantification of the carbonyl DNSAOA-oximes. This original approach, coupling both $\mathrm{AnCl}$ catalyzed derivatization and the use HPLC-MS allows us to quantify (i) single aldehydes (formaldehyde (F) and acetaldehyde (A)), (ii) polyfunctional aldehydes (hydroxyacetaldehyde (HyA), glyoxal (GL), and methylglyoxal (MGL)) and (iii) ketones (acetone (AC) and hydroxyacetone (HyAC)). To the best of our knowledge, this work provides the first measurements of HyAC in environmental water samples.

\section{Derivatization solutions}

All cloud water samples are collected in borosilicate glass vials and stored at $-20{ }^{\circ} \mathrm{C}$. For the same reasons, samples were analyzed immediately after their melting. Derivatization reactions are performed in $2 \mathrm{~mL}$ borosilicate glass vials preliminary cleaned with $\mathrm{HNO}_{3}(10 \% \mathrm{v} / \mathrm{v})$. A $1.2 \mathrm{~mL}$ aliquot of melted cloud water sample are added successively $300 \mu \mathrm{L}$ of a $0.5 \mathrm{M}$ solution of anilinium chloride (AnCl) and $25 \mu \mathrm{L}$ of a carbonyl adduct. $1 \mathrm{mM}$ stock solution of DNSAOA (Houdier et al., 2018). For calibration, the standard addition method is applied. Solutions (sample + standards) are allowed to react at room temperature for $12 \mathrm{~h}$ before analysis.

LC system and dual fluorescence / mass spectrometry analysis 
HPLC analyses are carried out by a system made of a Dionex GP 40 multi solvent delivery system, a Dionex ASI-100 automated sample injector (injection volume of $20 \mu \mathrm{L})$ and a Synergi Hydro-RP column $(250 \times 4.6 \mathrm{~mm}, 4 \mu \mathrm{m}$, Phenomenex $)$ maintained at $30{ }^{\circ} \mathrm{C}$. The mobile phase is made of water (A) and acetonitrile (B) containing $0.1 \%$ of formic acid. The gradient applied is the one fully described in Houdier et al. ( 2011) with a flow rate of $0.65 \mathrm{~mL} \mathrm{~min}^{-1}$. Fluorescence detection is by a Waters 2475 spectrometer with excitation and emissions wavelengths of 330 and $530 \mathrm{~nm}$, respectively. MS measurements are performed by an LCQ-FLEET (Thermos-Fisher) ion trap with negative mode electrospray ionization. Source voltage was set to $5 \mathrm{kV}$. The capillary is maintained at $385^{\circ} \mathrm{C}$ and the sheath, auxiliary and sweep gases were 15,0 , and 29 units, respectively. Molecular ions $[\mathrm{M}-\mathrm{H}]^{-}$are extracted from the full scan chromatograms using the Xcalibur software (Thermo Scientific). Concentrations reported in this work are established from MS measurements for all carbonyls except for MGL due to the low signal-to-noise $(\mathrm{SN})$ ratio observed for its MS signals. On the other hand, the fluorescence MGL peaks are well separated $\left(\mathrm{t}_{\mathrm{r}}=\right.$ $23.5 \mathrm{~min}$ ) from the other signals and characterized by a good $\mathrm{S} / \mathrm{N}$ ratio.

In cloud droplets, carbonyl compounds (in particular formaldehyde) form adducts with dissolved $\mathrm{SO}_{2}$. For instance, significant amounts of hydroxymethanesulfonate (HMSA), the adduct of HCHO, have been measured in the cloud or fog water where it constitutes a reservoir for both S(IV) species and HCHO (Ang et al., 1987; Munger et al., 1984). HMSA and more generally S(IV)-carbonyl adducts form rapidly and are stable towards dissociation in acidic media such as cloud droplets (Dasgupta et al., 1980; Munger et al., 1984). In this work, the derivatization of carbonyls by DNSAOA was performed in an acidified solution of the cloud sample ( $\mathrm{pH} 2.8$, related to aniline chlorhydrate $0.1 \mathrm{M}$ used here). Dissociation of the carbonyl-S(IV) adducts in the course of the derivatization reaction are therefore unlikely, and carbonyl concentrations reported in this paper represent the free carbonyl concentrations ([carb]free) and therefore lower estimates of the total carbonyl concentrations, with $[\mathrm{carb}]$ tot $=[\mathrm{carb}]$ free $+[\mathrm{S}(\mathrm{IV})-\mathrm{carb}]$.

\section{Method validation}

Linearities are assessed through the statistical analysis of the analytical curves established over the 0.13-2.5 and 0.065-1.2 $\mu \mathrm{mol} \mathrm{L} \mathrm{L}^{-1}$ ranges for $\mathrm{F}$ and the other carbonyls, respectively. The y-intercepts of the linear regression equations reported in Table S4 represent the initial contamination carried by the DNSAOA solution itself (Houdier et al., 2011). All analytical curves exhibited $R^{2}$ values systematically $>0.99$. Of all the $N=77$ concentration values, only 8 are slightly outside the calibration range.

Limits of detection (LOD) and quantification (LOQ) (Table S2) are determined as the equivalent concentration of 3 and 10 times, respectively, the standard deviation of $\mathrm{N}=5$ replicate analyses of the $0.065 \mu \mathrm{M}(0.13 \mu \mathrm{M}$ for FA) calibration solution. LOD are in the 2.0-7.4 nmol L-1 range for HyA, HyAC, GL, and MGL. Due to their lower response coefficients, higher LOD of $35 \mathrm{nmol} \mathrm{L}{ }^{-1}$ and $90 \mathrm{nmol} \mathrm{L}-1$ are measured for A and AC, respectively. F, the main atmospheric carbonyl compound, is ubiquitous in the lab air as well as on the surfaces, and contamination of the DNSAOA solution cannot be completely avoided (Houdier et al., 2011). Together with its modest response coefficient -similar to the ones of A and AC- this issue explains why F, with a LOD of $170 \mathrm{nmol} \mathrm{L}{ }^{-1}$, exhibits the lowest sensitivity. Nevertheless, it is noteworthy that no concentration data are found to be below the LOD for any of the molecules analyzed, including F. 
Table S4: Analytical performances of the carbonyl's method.

\begin{tabular}{|c|c|c|c|c|}
\hline Carbonyl (adduct) & Linear regression equation & $\mathbf{R}^{2}$ & $\begin{array}{c}\text { LOD (nmol } \\
\left.\mathbf{L}^{-1}\right)\end{array}$ & 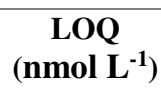 \\
\hline HyA ${ }^{(1)}$ & {[]$^{(3)}=2.52 .10^{-11} \times$ Area $^{(4)}-1.67 .10^{-8}$} & 0.9997 & 7.4 & 24.6 \\
\hline HyАC (1) & {[]$=4.19 .10^{-11} \times$ Area $-2.25 .10^{-9}$} & 0.9997 & 4.8 & 16.0 \\
\hline $\mathbf{F}^{(\mathbf{1})}$ & {[]$=2.54 .10^{-10} \times$ Area $-1.06 .10^{-6}$} & 0.9920 & 169 & 562 \\
\hline $\mathbf{A}^{(1)}$ & {[]$=2.69 .10^{-10} \times$ Area $-1.52 .10^{-7}$} & 0.9993 & 35.3 & 117 \\
\hline $\mathrm{AC}^{(1)}$ & {[]$=4.05 .10^{-10} \times$ Area $-3.34 .10^{-8}$} & 0.9916 & 89.5 & 298 \\
\hline GL & {[]$=2.32 .10^{-11} \times$ Area $-2.61 .10^{-8}$} & 0.9975 & 2.0 & 6.8 \\
\hline MGL (2) & {[]$=9.76 .10^{-10} \times$ Area $+1.08 .10^{-8}$} & 0.9992 & 4.5 & 14.8 \\
\hline
\end{tabular}

(1) Mass Spectrometry analysis

(2) Fluorescence analysis

(3) Concentration in $\mathrm{mol} \mathrm{L}^{-1}$

(4) Area in arbitrary units

Uncertainties that may result from the preparation of the reacting solutions, the derivatization reaction itself, variations of the eluent composition, fluctuations of the detector intensities, or imprecisions in peak integration are evaluated through the assay of $\mathrm{N}=3$ reacting solutions made with the same cloud water sample. This work is carried out for all samples for which a minimal volume $(4 \mathrm{~mL})$ is available, i.e. for 5 of the 11 collected samples. Results demonstrate good precisions, with mean relative standard deviations of the concentrations in the $3.5 \%$ (HAC) to $8.8 \%$ (AC) range and with no individual value exceeding 12.5 $\%$ (Table S4).

\section{Amino acids}

AAs are quantified by UPLC-HRMS (Ultra-High-Performance Liquid Chromatography coupled with High-Resolution Mass Spectrometry) using the standard addition method. For that, standard solutions prepared in ultra-pure water and containing the amino acids are used to spike cloud water samples at different concentrations. Twelve samples ready for UPLC-HRMS analysis are prepared to contain the original cloud water added with 19 AAs at final concentrations set to 0.1, 0.5, 1.0, 5.0, 10, 25, 50, 100, 150, $500 \mu \mathrm{g} \mathrm{L}^{-1}$. UPLC-HRMS analyses are performed using an UltiMate ${ }^{\mathrm{TM}} 3000$ (Thermo Scientific ${ }^{\mathrm{TM}}$ ) UPLC equipped with a Q Exactive ${ }^{\mathrm{TM}}$ Hybrid Quadrupole-Orbitrap ${ }^{\mathrm{TM}}$ Mass Spectrometer (Thermo Scientific ${ }^{\mathrm{TM}}$ ) ionization chamber. Chromatographic separation of the analytes is performed on BEH Amide/HILIC $(1.7 \mu \mathrm{m}, 100 \mathrm{~mm} \times 2.1 \mathrm{~mm})$ column with a column temperature of $30{ }^{\circ} \mathrm{C}$. The mobile phases consisted of $0.1 \%$ formic acid and water (A) and $0.1 \%$ formic acid and acetonitrile $(\mathrm{B})$ with a $0.4 \mathrm{~mL} \mathrm{~min}^{-1}$ flow rate, applied by a four-step linear-gradient during the analysis. The Q-Exactive ion source is equipped with electrospray ionization (ESI+) and the Q-Orbitrap ${ }^{\mathrm{TM}}$. Flow injection analyses are performed for individual amino acids solutions to obtain the mass spectral data, from which ions are carefully chosen for analysis in the selected ion monitoring (SIM) mode, using the above-mentioned parameter conditions. The mass resolution is set to 35000 fwhm (full width at half maximum of the peak), and the instrument is tuned for maximum ion throughput. AGC (automatic gain control) target or the number of ions to fill C-Trap is set to 105 with an injection time (IT) of 100 ms. More details about this technique can be found in recent work from Renard et al. (2021).

\section{Uncertainties}

The magnitude of the intercept on the x-axis is the original concentration of glycine (Gly). The main calculations are briefly recalled below and fully described in Renard et al. (2021). The equation of the trendline is $y=a x+b$. The $x \_$intercept is obtained by setting $y=0: x=-b / a$, with $a=$ slope of the curve, $b=$ y_intercept, $x=$ the concentration of the AA, and $y=$ the mass spectral area:

$$
\text { Gly: } a=6199.8 ; b=272312 \quad \rightarrow \quad \mid x \_ \text {intercept } \mid=[\text { Gly }]=43.9 \mu g^{-1} \text { (negative value) }
$$


The obtained values are then corrected by the dilution factor of $10 \%$ (due to the ratio 9:1 volume cloud: volume added standard). Thus, the final value is: $[\mathrm{Gly}]=43.9 \times \frac{10}{9}=48.8 \mu \mathrm{g} \mathrm{L}^{-1}$.

The uncertainty in the $x \_$intercept is $s_{x}$ :

$$
s_{x}=\frac{s_{y}}{|a|} \sqrt{\frac{1}{n}+\frac{\bar{y}^{2}}{a^{2} \times \sum\left(x_{i}-\bar{x}\right)^{2}}}
$$

where $a$ is the absolute value of the slope of the trendline, $n$ is the number of data points, $\bar{y}$ is the mean value of $y$ for the points, $x_{i}$ are the individual values of $\mathrm{x}, \bar{x}$ is the mean value of $\mathrm{y}$ for the points, and $s_{y}$ is the standard deviation for $\mathrm{y}$ :

$$
s_{y}=\sqrt{\frac{1}{(n-2)} \times\left[\sum\left((y-\bar{y})^{2}-\frac{\left[\sum(x-\bar{x})(y-\bar{y})\right]^{2}}{\sum(x-\bar{x})^{2}}\right]\right.}
$$

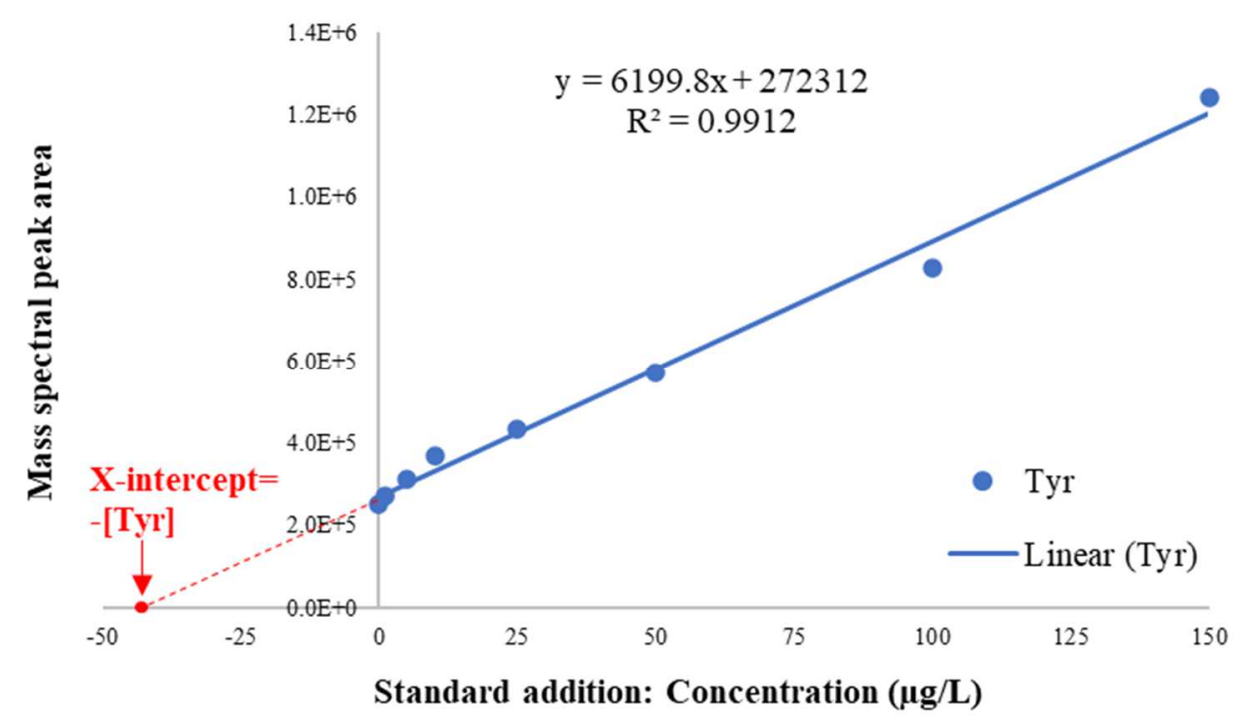

Figure S1. Quantification of amino acid concentrations in cloud R13 using the addition standard method: a case study of Tyr. 


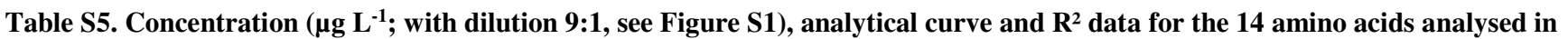
the 12 clouds sampled at BIO-MAÏDO.

\begin{tabular}{|c|c|c|c|c|}
\hline \multicolumn{5}{|c|}{$\mathbf{R 1}$} \\
\hline AA & Conc & $\begin{array}{l}\left.\mathrm{L}^{-1}\right) \\
\text { tration }\end{array}$ & Eq. of analytical curve & $\mathrm{R}^{2}$ \\
\hline Ala & 26 & \pm & $y=3.8 E+3 x+9.9 E+4$ & 0.9919 \\
\hline Arg & 7.0 & $\pm \quad 0.9$ & $y=1.5 \mathrm{E}+5 \mathrm{x}+1.0 \mathrm{E}+6$ & 0.9986 \\
\hline Asn & 8 & \pm & $y=7.9 E+3 x+6.4 E+4$ & 0.9974 \\
\hline Asp & 21 & \pm 6 & $y=2.2 E+3 x+4.5 E+4$ & 0.9742 \\
\hline Gln & 5 & \pm & $y=1.3 \mathrm{E}+4 x+6.1 \mathrm{E}+4$ & 0.9929 \\
\hline Glu & 12 & \pm 4 & $\mathrm{y}=1.0 \mathrm{E}+4 \mathrm{x}+1.2 \mathrm{E}+5$ & 0.9804 \\
\hline His & 4.2 & $\pm \quad 0.6$ & $y=1.1 E+5 x+4.7 E+5$ & 0.9993 \\
\hline Lys & 8.9 & $\pm \quad 0.6$ & $\mathrm{y}=2.0 \mathrm{E}+4 \mathrm{x}+1.8 \mathrm{E}+5$ & 0.9994 \\
\hline Met & 3 & \pm 7 & $y=1.9 E+4 x+5.8 E+4$ & 0.9677 \\
\hline Phe & 17 & \pm 1 & $y=1.6 E+4 x+2.8 E+5$ & 0.9991 \\
\hline Ser & 106 & \pm 18 & $y=6.6 \mathrm{E}+3 x+7.0 \mathrm{E}+5$ & 0.9391 \\
\hline Thr & 46 & \pm 8 & $y=5.3 E+3 x+2.4 E+5$ & 0.9581 \\
\hline Trp & 0.7 & $\pm \quad 0.5$ & $y=6.3 E+3 x+4.5 E+3$ & 0.9997 \\
\hline Tyr & 60 & $\pm \quad 10$ & $y=1.2 E+4 x+7.3 E+5$ & 0.9500 \\
\hline
\end{tabular}

\begin{tabular}{|c|c|c|c|c|}
\hline \multicolumn{5}{|c|}{$\mathbf{R 3}$} \\
\hline AA & Con & $\begin{array}{l}\text { atration } \\
\left.\mathrm{L}^{-1}\right)\end{array}$ & Eq. of analytical curve & $\mathrm{R}^{2}$ \\
\hline Ala & 18 & \pm & $\mathrm{y}=3.8 \mathrm{E}+3 \mathrm{x}+6.9 \mathrm{E}+4$ & 0.9788 \\
\hline Arg & 16 & $\pm \quad 2$ & $y=1.6 \mathrm{E}+5 x+2.6 \mathrm{E}+6$ & 0.9977 \\
\hline Asn & 4.8 & $\pm \quad 0.5$ & $\mathrm{y}=8.7 \mathrm{E}+3 \mathrm{x}+4.2 \mathrm{E}+4$ & 0.9998 \\
\hline Asp & 4 & $\pm \quad 1$ & $\mathrm{y}=2.3 \mathrm{E}+3 \mathrm{x}+8.9 \mathrm{E}+3$ & 0.9949 \\
\hline Gln & 8 & $\pm \quad 1$ & $\mathrm{y}=1.4 \mathrm{E}+4 \mathrm{x}+1.1 \mathrm{E}+5$ & 0.9984 \\
\hline Glu & 13 & $\pm \quad 2$ & $y=1.1 E+4 x+1.4 E+5$ & 0.9843 \\
\hline His & 3 & $\pm \quad 2$ & $\mathrm{y}=1.9 \mathrm{E}+5 \mathrm{x}+6.6 \mathrm{E}+5$ & 0.9935 \\
\hline Lys & 7.9 & $\pm \quad 0.8$ & $\mathrm{y}=2.1 \mathrm{E}+4 \mathrm{x}+1.7 \mathrm{E}+5$ & 0.9969 \\
\hline Met & -2 & $\pm \quad 2$ & $\mathrm{y}=1.5 \mathrm{E}+4 \mathrm{x}-3.7 \mathrm{E}+4$ & 0.9992 \\
\hline Phe & 19 & \pm 3 & $y=1.7 E+4 x+3.3 E+5$ & 0.9931 \\
\hline Ser & 21 & $\pm \quad 1$ & $\mathrm{y}=7.5 \mathrm{E}+3 \mathrm{x}+1.6 \mathrm{E}+5$ & 0.9983 \\
\hline Thr & 12 & $\pm \quad 2$ & $y=6.3 E+3 x+7.8 E+4$ & 0.9951 \\
\hline Trp & 0 & $\pm \quad 1$ & $y=6.9 E+3 x+1.5 E+3$ & 0.9976 \\
\hline Tyr & 66 & $\pm \quad 7$ & $y=5.2 E+3 x+3.4 E+5$ & 0.9806 \\
\hline
\end{tabular}

\begin{tabular}{|c|c|c|c|c|}
\hline \multicolumn{5}{|c|}{$\mathbf{R 2}$} \\
\hline AA & $\begin{array}{r}\text { Conc } \\
(\mu\end{array}$ & $\begin{array}{l}\text { atration } \\
\mathrm{L}^{-1} \text { ) }\end{array}$ & Eq. of analytical curve & $\mathrm{R}^{2}$ \\
\hline Ala & 1 & \pm & $y=4.1 E+3 x+5.1 E+3$ & 0.9987 \\
\hline Arg & 9.1 & $\pm \quad 0.7$ & $y=1.4 \mathrm{E}+5 \mathrm{x}+1.3 \mathrm{E}+6$ & 0.9996 \\
\hline Asn & 2.0 & \pm 0.5 & $y=9.2 \mathrm{E}+3 x+1.9 \mathrm{E}+4$ & 0.9997 \\
\hline Asp & 0 & $\pm \quad 2$ & $y=2.7 \mathrm{E}+3 x-1.1 \mathrm{E}+3$ & 0.9978 \\
\hline Gln & 6.9 & \pm 0.8 & $y=1.2 \mathrm{E}+4 x+8.6 \mathrm{E}+4$ & 0.9978 \\
\hline Glu & 5.0 & $\pm \quad 0.6$ & $y=1.1 E+4 x+5.4 E+4$ & 0.9985 \\
\hline His & 0.6 & $\pm \quad 0.2$ & $y=1.1 E+5 x+7.4 E+4$ & 1.0000 \\
\hline Lys & 1.9 & $\pm \quad 0.8$ & $y=1.8 \mathrm{E}+4 x+3.3 \mathrm{E}+4$ & 0.9993 \\
\hline Met & 0.1 & $\pm \quad 0.7$ & $\mathrm{y}=2.0 \mathrm{E}+4 \mathrm{x}+2.2 \mathrm{E}+3$ & 0.9974 \\
\hline Phe & 9 & \pm 3 & $\mathrm{y}=2.0 \mathrm{E}+4 \mathrm{x}+1.9 \mathrm{E}+5$ & 0.9915 \\
\hline Ser & 5 & \pm & $\mathrm{y}=8.4 \mathrm{E}+3 \mathrm{x}+4.4 \mathrm{E}+4$ & 0.9991 \\
\hline Thr & 7 & $\begin{array}{ll} \pm \quad 1 \\
\end{array}$ & $y=5.7 E+3 x+4.2 E+4$ & 0.9923 \\
\hline Trp & -1.3 & $\pm \quad 1.0$ & $y=7.0 \mathrm{E}+3 x-9.5 \mathrm{E}+3$ & 0.9990 \\
\hline Tyr & 37 & \pm 6 & $y=6.5 E+3 x+2.4 E+5$ & 0.9628 \\
\hline
\end{tabular}

\begin{tabular}{|c|c|c|c|c|}
\hline \multicolumn{5}{|c|}{ R4 } \\
\hline AA & $\begin{array}{r}\text { Conc } \\
(\mu\end{array}$ & $\begin{array}{l}\text { atration } \\
\left.\mathrm{L}^{-1}\right)\end{array}$ & Eq. of analytical curve & $\mathrm{R}^{2}$ \\
\hline Ala & 38 & \pm 2 & $y=4.3 E+3 x+1.7 E+5$ & 0.9984 \\
\hline Arg & & $\pm \quad 0.4$ & $\mathrm{y}=1.5 \mathrm{E}+5 \mathrm{x}+1.1 \mathrm{E}+6$ & 0.9997 \\
\hline Asn & 3.0 & $\pm \quad 0.4$ & $\mathrm{y}=8.4 \mathrm{E}+3 \mathrm{x}+2.5 \mathrm{E}+4$ & 0.9999 \\
\hline Asp & 4 & $\begin{array}{ll} \pm & 4\end{array}$ & $y=2.5 E+3 x+9.8 E+3$ & 0.9885 \\
\hline Gln & 10.5 & $\pm \quad 0.8$ & $\mathrm{y}=1.3 \mathrm{E}+4 \mathrm{x}+1.4 \mathrm{E}+5$ & 0.9994 \\
\hline Glu & 10 & \pm 3 & $y=1.1 E+4 x+1.1 E+5$ & 0.9914 \\
\hline His & 3 & $\pm \quad 2$ & $y=1.1 E+5 x+3.5 E+5$ & 0.9934 \\
\hline Lys & 3.7 & $\pm \quad 1.0$ & $\mathrm{y}=2.0 \mathrm{E}+4 \mathrm{x}+7.2 \mathrm{E}+4$ & 0.9977 \\
\hline Met & 4 & \pm 6 & $\mathrm{y}=1.1 \mathrm{E}+4 \mathrm{x}+4.8 \mathrm{E}+4$ & 0.9320 \\
\hline Phe & 11.7 & $\pm \quad 0.7$ & $\mathrm{y}=1.8 \mathrm{E}+4 \mathrm{x}+2.1 \mathrm{E}+5$ & 0.9983 \\
\hline Ser & 31 & \pm 3 & $y=8.1 E+3 x+2.5 E+5$ & 0.9941 \\
\hline Thr & & \pm 3 & $\mathrm{y}=6.5 \mathrm{E}+3 \mathrm{x}+1.0 \mathrm{E}+5$ & 0.9918 \\
\hline Trp & 3 & \pm 3 & $\mathrm{y}=4.0 \mathrm{E}+3 \mathrm{x}+1.2 \mathrm{E}+4$ & 0.9804 \\
\hline Tyr & 7 & \pm 2 & $y=5.2 E+3 x+3.7 E+4$ & 0.9946 \\
\hline
\end{tabular}


Table S5. (Continuation)

\section{R5}

\begin{tabular}{cccccc}
\hline AA & $\begin{array}{c}\text { Concentration } \\
\left(\mu \mathrm{L} \mathrm{L}^{-1}\right)\end{array}$ & Eq. of analytical curve & $\mathrm{R}^{2}$ \\
\hline Ala & 41 & \pm & 4 & $\mathrm{y}=5.0 \mathrm{E}+3 \mathrm{x}+2.1 \mathrm{E}+5$ & 0.9933 \\
\hline Arg & 19 & \pm & 0.6 & $\mathrm{y}=1.3 \mathrm{E}+5 \mathrm{x}+2.5 \mathrm{E}+6$ & 0.9995 \\
\hline Asn & 5.6 & \pm & 0.4 & $\mathrm{y}=8.1 \mathrm{E}+3 \mathrm{x}+4.5 \mathrm{E}+4$ & 0.9999 \\
\hline Asp & 14.2 & \pm & 0.7 & $\mathrm{y}=2.3 \mathrm{E}+3 \mathrm{x}+3.3 \mathrm{E}+4$ & 0.9996 \\
\hline Gln & 11 & \pm & 1 & $\mathrm{y}=1.3 \mathrm{E}+4 \mathrm{x}+1.4 \mathrm{E}+5$ & 0.9987 \\
\hline Glu & 14.9 & \pm & 0.9 & $\mathrm{y}=1.3 \mathrm{E}+4 \mathrm{x}+1.9 \mathrm{E}+5$ & 0.9993 \\
\hline His & 8.6 & \pm & 0.6 & $\mathrm{y}=1.0 \mathrm{E}+5 \mathrm{x}+8.7 \mathrm{E}+5$ & 0.9992 \\
\hline Lys & 8.2 & \pm & 0.7 & $\mathrm{y}=1.7 \mathrm{E}+4 \mathrm{x}+1.4 \mathrm{E}+5$ & 0.9990 \\
\hline Met & -1.4 & \pm & 0.3 & $\mathrm{y}=1.7 \mathrm{E}+4 \mathrm{x}-2.3 \mathrm{E}+4$ & 0.9999 \\
\hline Phe & 17 & \pm & 1 & $\mathrm{y}=1.5 \mathrm{E}+4 \mathrm{x}+2.6 \mathrm{E}+5$ & 0.9993 \\
\hline Tre & 60 & \pm & 6 & $\mathrm{y}=7.2 \mathrm{E}+3 \mathrm{x}+4.4 \mathrm{E}+5$ & 0.9877 \\
\hline Thr & 16 & \pm & 1 & $\mathrm{y}=6.6 \mathrm{E}+3 \mathrm{x}+1.1 \mathrm{E}+5$ & 0.9993 \\
\hline & 0.5 & \pm & 0.9 & $\mathrm{y}=5.3 \mathrm{E}+3 \mathrm{x}+2.8 \mathrm{E}+3$ & 0.9977 \\
\hline Trp & 58 & \pm & 1 & $\mathrm{y}=4.4 \mathrm{E}+3 \mathrm{x}+2.6 \mathrm{E}+5$ & 0.9995 \\
\hline & & & & & \\
\hline
\end{tabular}

R8

\begin{tabular}{|c|c|c|c|c|}
\hline AA & $\begin{array}{r}\text { Conc } \\
(\mu\end{array}$ & $\begin{array}{l}\text { ntration } \\
\left.\mathrm{L}^{-1}\right)\end{array}$ & Eq. of analytical curve & $\mathrm{R}^{2}$ \\
\hline Ala & 26 & $\pm \quad 2$ & $\mathrm{y}=7.8 \mathrm{E}+3 \mathrm{x}+2.0 \mathrm{E}+5$ & 0.9979 \\
\hline Arg & 16 & $\begin{array}{ll} \pm & 1\end{array}$ & $\mathrm{y}=1.5 \mathrm{E}+5 \mathrm{x}+2.3 \mathrm{E}+6$ & 0.9986 \\
\hline Asn & 4 & $\begin{array}{ll} \pm \quad 1 \\
\end{array}$ & $\mathrm{y}=8.5 \mathrm{E}+3 \mathrm{x}+3.6 \mathrm{E}+4$ & 0.9985 \\
\hline Asp & 15 & \pm 2 & $y=2.7 \mathrm{E}+3 \mathrm{x}+4.0 \mathrm{E}+4$ & 0.9961 \\
\hline GIn & 5 & $\begin{array}{ll} \pm & 1\end{array}$ & $y=1.4 \mathrm{E}+4 x+6.8 \mathrm{E}+4$ & 0.9988 \\
\hline Glu & 12.4 & $\pm \quad 1.0$ & $y=1.3 E+4 x+1.6 E+5$ & 0.9990 \\
\hline Gly & 55 & $\pm \quad 11$ & $\mathrm{y}=1.2 \mathrm{E}+3 \mathrm{x}+6.4 \mathrm{E}+4$ & 0.9593 \\
\hline His & 10 & $\pm \quad 1$ & $y=1.2 \mathrm{E}+5 x+1.2 \mathrm{E}+6$ & 0.9964 \\
\hline Lys & 10 & $\pm \quad 1$ & $y=2.1 E+4 x+2.1 E+5$ & 0.9959 \\
\hline Met & -3 & $\pm \quad 1$ & $y=2.1 E+4 x-5.4 E+4$ & 0.9985 \\
\hline Phe & 14.7 & $\pm \quad 0.8$ & $y=1.7 E+4 x+2.5 E+5$ & 0.9993 \\
\hline Ser & 85 & \pm 5 & $y=7.1 E+3 x+6.0 E+5$ & 0.9915 \\
\hline Thr & 22.4 & $\pm \quad 0.5$ & $y=6.5 E+3 x+1.5 E+5$ & 0.9998 \\
\hline Trp & 0.1 & $\pm \quad 0.9$ & $y=6.8 \mathrm{E}+3 x+4.0 \mathrm{E}+2$ & 0.9988 \\
\hline Tyr & 25 & $\pm \quad 1$ & $y=4.7 E+3 x+1.2 E+5$ & 0.9984 \\
\hline
\end{tabular}

\section{R7}

\begin{tabular}{|c|c|c|c|c|}
\hline AA & $\begin{array}{r}\text { Conc } \\
(\mu\end{array}$ & $\begin{array}{l}\text { tration } \\
\left.\mathrm{L}^{-1}\right)\end{array}$ & Eq. of analytical curve & $\mathrm{R}^{2}$ \\
\hline Ala & 30 & \pm 4 & $\mathrm{y}=4.4 \mathrm{E}+3 \mathrm{x}+1.3 \mathrm{E}+5$ & 0.9819 \\
\hline Arg & 15 & $\pm \quad 0.4$ & $y=1.7 E+5 x+2.5 E+6$ & 0.9997 \\
\hline Asn & 6.2 & $\pm \quad 0.6$ & $y=8.6 \mathrm{E}+3 x+5.3 \mathrm{E}+4$ & 0.9995 \\
\hline Asp & 5 & \pm & $y=2.9 E+3 x+1.5 E+4$ & 0.9974 \\
\hline Gln & 8.7 & $\pm \quad 0.9$ & $y=1.4 \mathrm{E}+4 x+1.2 \mathrm{E}+5$ & 0.9991 \\
\hline Glu & 11.7 & $\pm \quad 1.0$ & $y=1.2 \mathrm{E}+4 x+1.4 \mathrm{E}+5$ & 0.9982 \\
\hline His & 2.7 & $\pm \quad 0.5$ & $y=2.3 E+5 x+6.3 E+5$ & 0.9994 \\
\hline Lys & 6.8 & $\pm \quad 0.7$ & $y=2.3 E+4 x+1.6 E+5$ & 0.9989 \\
\hline Met & 2 & \pm 3 & $y=1.5 E+4 x+2.6 E+4$ & 0.9941 \\
\hline Phe & 13 & $\pm \quad 2$ & $y=2.0 \mathrm{E}+4 x+2.5 \mathrm{E}+5$ & 0.9956 \\
\hline Ser & 15 & \pm 2 & $y=1.1 E+4 x+1.6 E+5$ & 0.9925 \\
\hline Thr & 12.9 & $\begin{array}{ll} \pm \quad 0.7 \\
\end{array}$ & $y=6.6 \mathrm{E}+3 x+8.5 \mathrm{E}+4$ & 0.9991 \\
\hline Trp & 0 & $\begin{array}{ll} \pm & 1\end{array}$ & $y=6.4 E+3 x+6.5 E+2$ & 0.9978 \\
\hline Tyr & 47 & \pm & $y=6.5 E+3 x+3.1 E+5$ & 0.9982 \\
\hline
\end{tabular}

\section{R9}

\begin{tabular}{|c|c|c|c|c|}
\hline AA & $\begin{array}{r}\text { Conc } \\
(\mu\end{array}$ & $\begin{array}{l}\text { tration } \\
\left.\mathrm{L}^{-1}\right)\end{array}$ & Eq. of analytical curve & $\mathrm{R}^{2}$ \\
\hline Ala & 19 & \pm & $y=1.1 E+4 x+2.1 E+5$ & 0.9986 \\
\hline Arg & 15.7 & $\pm \quad 0.9$ & $y=1.6 E+5 x+2.5 E+6$ & 0.9988 \\
\hline Asn & 2.6 & $\pm \quad 0.4$ & $\mathrm{y}=9.4 \mathrm{E}+3 \mathrm{x}+2.4 \mathrm{E}+4$ & 0.9998 \\
\hline Asp & 11 & \pm & $y=2.5 E+3 x+2.7 E+4$ & 0.9989 \\
\hline Gln & 6 & \pm & $y=1.4 E+4 x+8.5 E+4$ & 0.9983 \\
\hline Glu & 10.6 & $\pm \quad 0.6$ & $y=1.3 \mathrm{E}+4 x+1.4 \mathrm{E}+5$ & 0.9996 \\
\hline Gly & 31 & \pm & $y=1.1 E+3 x+3.4 E+4$ & 0.9965 \\
\hline His & 5.8 & $\pm \quad 0.7$ & $y=1.1 E+5 x+6.3 E+5$ & 0.9988 \\
\hline Lys & 4.6 & $\pm \quad 0.6$ & $\mathrm{y}=2.0 \mathrm{E}+4 \mathrm{x}+9.1 \mathrm{E}+4$ & 0.9991 \\
\hline Met & -3 & \pm & $\mathrm{y}=1.9 \mathrm{E}+4 x-6.3 \mathrm{E}+4$ & 0.9971 \\
\hline Phe & 10.9 & $\pm \quad 0.6$ & $y=1.8 \mathrm{E}+4 x+2.0 \mathrm{E}+5$ & 0.9997 \\
\hline Ser & 34 & \pm 2 & $y=7.9 E+3 x+2.7 E+5$ & 0.9975 \\
\hline Thr & 9.7 & $\pm \quad 0.6$ & $y=7.0 \mathrm{E}+3 x+6.8 \mathrm{E}+4$ & 0.9996 \\
\hline Trp & -3.8 & $\pm \quad 0.9$ & $y=6.6 \mathrm{E}+3 x-2.5 \mathrm{E}+4$ & 0.9996 \\
\hline Tyr & 10 & \pm 4 & $y=6.8 \mathrm{E}+3 x+7.0 \mathrm{E}+4$ & 0.9910 \\
\hline
\end{tabular}


Table S5. (Continuation)

\begin{tabular}{lccclc}
\hline \multicolumn{5}{c}{ R10A } \\
\hline AA & $\begin{array}{c}\text { Concentration } \\
\left(\mu \mathrm{g} \mathrm{L}^{-1}\right)\end{array}$ & Eq. of analytical curve & $\mathrm{R}^{2}$ \\
\hline Ala & 93 & \pm & 7 & $\mathrm{y}=1.1 \mathrm{E}+4 \mathrm{x}+1.0 \mathrm{E}+6$ & 0.9897 \\
\hline Arg & 32 & \pm & 3 & $\mathrm{y}=1.9 \mathrm{E}+5 \mathrm{x}+6.0 \mathrm{E}+6$ & 0.9952 \\
\hline Asn & 18 & \pm & 1 & $\mathrm{y}=8.2 \mathrm{E}+3 \mathrm{x}+1.5 \mathrm{E}+5$ & 0.9991 \\
\hline Asp & 70 & \pm & 3 & $\mathrm{y}=2.6 \mathrm{E}+3 \mathrm{x}+1.8 \mathrm{E}+5$ & 0.9969 \\
\hline Gln & 25 & \pm & 1 & $\mathrm{y}=1.5 \mathrm{E}+4 \mathrm{x}+3.8 \mathrm{E}+5$ & 0.9989 \\
\hline Glu & 53 & \pm & 3 & $\mathrm{y}=1.3 \mathrm{E}+4 \mathrm{x}+7.1 \mathrm{E}+5$ & 0.9961 \\
\hline Gly & 93 & \pm & 6 & $\mathrm{y}=1.3 \mathrm{E}+3 \mathrm{x}+1.2 \mathrm{E}+5$ & 0.9957 \\
\hline His & 18 & \pm & 1 & $\mathrm{y}=2.5 \mathrm{E}+5 \mathrm{x}+4.4 \mathrm{E}+6$ & 0.9968 \\
\hline Lys & 20 & \pm & 2 & $\mathrm{y}=2.9 \mathrm{E}+4 \mathrm{x}+5.8 \mathrm{E}+5$ & 0.9937 \\
\hline Met & -3 & \pm & 1 & $\mathrm{y}=1.4 \mathrm{E}+4 \mathrm{x}-4.7 \mathrm{E}+4$ & 0.9990 \\
\hline Phe & 13 & \pm & 1 & $\mathrm{y}=4.3 \mathrm{E}+4 \mathrm{x}+5.8 \mathrm{E}+5$ & 0.9984 \\
\hline Ser & 264 & \pm & 16 & $\mathrm{y}=7.1 \mathrm{E}+3 \mathrm{x}+1.9 \mathrm{E}+6$ & 0.9876 \\
\hline Thr & 58 & \pm & 2 & $\mathrm{y}=6.4 \mathrm{E}+3 \mathrm{x}+3.7 \mathrm{E}+5$ & 0.9979 \\
\hline Trp & -1 & \pm & 3 & $\mathrm{y}=1.5 \mathrm{E}+4 \mathrm{x}-2.3 \mathrm{E}+4$ & 0.9944 \\
\hline Tyr & 32 & \pm & 3 & $\mathrm{y}=6.1 \mathrm{E}+3 \mathrm{x}+2.0 \mathrm{E}+5$ & 0.9932 \\
\hline & & & & \\
\hline
\end{tabular}

\section{R11}

\begin{tabular}{lccccc}
\hline AA & $\begin{array}{c}\text { Concentration } \\
\left(\mu \mathrm{g} \mathrm{L}^{-1}\right)\end{array}$ & Eq. of Analytical curve & $\mathrm{R}^{2}$ \\
\hline Ala & 250 & \pm & 18 & $\mathrm{y}=8.3 \mathrm{E}+3 \mathrm{x}+2.1 \mathrm{E}+6$ & 0.9873 \\
\hline Arg & 59 & \pm & 3 & $\mathrm{y}=1.8 \mathrm{E}+5 \mathrm{x}+1.1 \mathrm{E}+7$ & 0.9971 \\
\hline Asn & 32 & \pm & 3 & $\mathrm{y}=8.5 \mathrm{E}+3 \mathrm{x}+2.7 \mathrm{E}+5$ & 0.9941 \\
\hline Asp & 151 & \pm & 15 & $\mathrm{y}=3.2 \mathrm{E}+3 \mathrm{x}+4.9 \mathrm{E}+5$ & 0.9792 \\
\hline Gln & 62 & \pm & 5 & $\mathrm{y}=1.8 \mathrm{E}+4 \mathrm{x}+1.1 \mathrm{E}+6$ & 0.9931 \\
\hline Glu & 67 & \pm & 4 & $\mathrm{y}=1.5 \mathrm{E}+4 \mathrm{x}+1.0 \mathrm{E}+6$ & 0.9947 \\
\hline Gly & & & & $\mathrm{n} . \mathrm{d}$. & \\
\hline His & 65 & \pm & 5 & $\mathrm{y}=1.4 \mathrm{E}+5 \mathrm{x}+9.4 \mathrm{E}+6$ & 0.9890 \\
\hline Lys & 60 & \pm & 7 & $\mathrm{y}=2.8 \mathrm{E}+4 \mathrm{x}+1.7 \mathrm{E}+6$ & 0.9812 \\
\hline Met & -9 & \pm & 13 & $\mathrm{y}=1.0 \mathrm{E}+4 \mathrm{x}-9.5 \mathrm{E}+4$ & 0.9184 \\
\hline Phe & 43 & \pm & 2 & $\mathrm{y}=2.4 \mathrm{E}+4 \mathrm{x}+1.0 \mathrm{E}+6$ & 0.9990 \\
\hline Ser & & & & & \\
\hline Thr & 118 & \pm & 16 & $\mathrm{y}=7.8 \mathrm{E}+3 \mathrm{x}+9.2 \mathrm{E}+5$ & 0.9676 \\
\hline Trp & 4 & \pm & 4 & $\mathrm{y}=6.7 \mathrm{E}+3 \mathrm{x}+2.6 \mathrm{E}+4$ & 0.9882 \\
\hline Tyr & 118 & \pm & 5 & $\mathrm{y}=5.3 \mathrm{E}+3 \mathrm{x}+6.3 \mathrm{E}+5$ & 0.9970 \\
\hline
\end{tabular}

\begin{tabular}{cccccc}
\hline \multicolumn{7}{c}{ R10B } \\
\hline AA & $\begin{array}{c}\text { Concentration } \\
\left(\mu \mathrm{g} \mathrm{L}^{-1}\right)\end{array}$ & Eq. of analytical curve & $\mathrm{R}^{2}$ \\
\hline Ala & 29 & \pm & 4 & $\mathrm{y}=1.3 \mathrm{E}+4 \mathrm{x}+3.9 \mathrm{E}+5$ & 0.9873 \\
\hline Arg & 18 & \pm & 4 & $\mathrm{y}=1.4 \mathrm{E}+5 \mathrm{x}+2.6 \mathrm{E}+6$ & 0.9901 \\
\hline Asn & 9.0 & \pm & 0.8 & $\mathrm{y}=8.5 \mathrm{E}+3 \mathrm{x}+7.6 \mathrm{E}+4$ & 0.9996 \\
\hline Asp & 15 & \pm & 4 & $\mathrm{y}=3.0 \mathrm{E}+3 \mathrm{x}+4.4 \mathrm{E}+4$ & 0.9725 \\
\hline Gln & 15 & \pm & 1 & $\mathrm{y}=1.4 \mathrm{E}+4 \mathrm{x}+2.0 \mathrm{E}+5$ & 0.9993 \\
\hline Glu & 15 & \pm & 4 & $\mathrm{y}=1.2 \mathrm{E}+4 \mathrm{x}+1.9 \mathrm{E}+5$ & 0.9864 \\
\hline Gly & 34 & \pm & 16 & $\mathrm{y}=1.4 \mathrm{E}+3 \mathrm{x}+4.6 \mathrm{E}+4$ & 0.9688 \\
\hline His & 12 & \pm & 2 & $\mathrm{y}=1.1 \mathrm{E}+5 \mathrm{x}+1.3 \mathrm{E}+6$ & 0.9959 \\
\hline Lys & 10 & \pm & 1 & $\mathrm{y}=2.1 \mathrm{E}+4 \mathrm{x}+2.1 \mathrm{E}+5$ & 0.9984 \\
\hline Met & -10 & \pm & 5 & $\mathrm{y}=1.2 \mathrm{E}+4 \mathrm{x}-1.3 \mathrm{E}+5$ & 0.9791 \\
\hline Phe & 16.0 & \pm & 0.8 & $\mathrm{y}=1.9 \mathrm{E}+4 \mathrm{x}+3.0 \mathrm{E}+5$ & 0.9995 \\
\hline Ser & 101 & \pm & 4 & $\mathrm{y}=7.0 \mathrm{E}+3 \mathrm{x}+7.1 \mathrm{E}+5$ & 0.9970 \\
\hline Thr & 15 & \pm & 5 & $\mathrm{y}=7.2 \mathrm{E}+3 \mathrm{x}+1.1 \mathrm{E}+5$ & 0.9793 \\
\hline Trp & 0.5 & \pm & 1.0 & $\mathrm{y}=6.7 \mathrm{E}+3 \mathrm{x}+3.2 \mathrm{E}+3$ & 0.9987 \\
\hline Tyr & 23 & \pm & 2 & $\mathrm{y}=5.5 \mathrm{E}+3 \mathrm{x}+1.3 \mathrm{E}+5$ & 0.9967 \\
\hline & & & & \\
\hline
\end{tabular}

\section{R13}

\begin{tabular}{cccc}
\hline $\mathrm{AA}$ & $\begin{array}{c}\text { Concentration } \\
\left(\mu \mathrm{g} \mathrm{L}^{-1}\right)\end{array}$ & Eq. of analytical curve & $\mathrm{R}^{2}$ \\
\hline
\end{tabular}

\begin{tabular}{cccccc}
\hline Ala & 65 & \pm & 3 & $\mathrm{y}=1.7 \mathrm{E}+4 \mathrm{x}+1.1 \mathrm{E}+6$ & 0.9973 \\
\hline Arg & 29 & \pm & 1 & $\mathrm{y}=1.7 \mathrm{E}+5 \mathrm{x}+5.1 \mathrm{E}+6$ & 0.9992 \\
\hline Asn & 12.5 & \pm & 0.9 & $\mathrm{y}=9.7 \mathrm{E}+3 \mathrm{x}+1.2 \mathrm{E}+5$ & 0.9991 \\
\hline Asp & 56 & \pm & 3 & $\mathrm{y}=2.4 \mathrm{E}+3 \mathrm{x}+1.4 \mathrm{E}+5$ & 0.9966 \\
\hline Gln & 22 & \pm & 1 & $\mathrm{y}=1.6 \mathrm{E}+4 \mathrm{x}+3.5 \mathrm{E}+5$ & 0.9987 \\
\hline Glu & 31 & \pm & 1 & $\mathrm{y}=1.6 \mathrm{E}+4 \mathrm{x}+4.9 \mathrm{E}+5$ & 0.9988 \\
\hline Gly & 66 & \pm & 3 & $\mathrm{y}=1.4 \mathrm{E}+3 \mathrm{x}+9.5 \mathrm{E}+4$ & 0.9982 \\
\hline His & 17.1 & \pm & 0.6 & $\mathrm{y}=1.2 \mathrm{E}+5 \mathrm{x}+2.1 \mathrm{E}+6$ & 0.9996 \\
\hline Lys & 21.9 & \pm & 0.7 & $\mathrm{y}=2.4 \mathrm{E}+4 \mathrm{x}+5.3 \mathrm{E}+5$ & 0.9995 \\
\hline Met & -3 & \pm & 1 & $\mathrm{y}=1.6 \mathrm{E}+4 \mathrm{x}-4.8 \mathrm{E}+4$ & 0.9988 \\
\hline Phe & 23 & \pm & 2 & $\mathrm{y}=2.4 \mathrm{E}+4 \mathrm{x}+5.5 \mathrm{E}+5$ & 0.9944 \\
\hline Ser & 167 & \pm & 8 & $\mathrm{y}=7.8 \mathrm{E}+3 \mathrm{x}+1.3 \mathrm{E}+6$ & 0.9932 \\
\hline Thr & 34 & \pm & 1 & $\mathrm{y}=7.8 \mathrm{E}+3 \mathrm{x}+2.7 \mathrm{E}+5$ & 0.9991 \\
\hline Trp & 0.3 & \pm & 0.5 & $\mathrm{y}=1.4 \mathrm{E}+4 \mathrm{x}+3.6 \mathrm{E}+3$ & 0.9996 \\
\hline Tyr & 44 & \pm & 4 & $\mathrm{y}=6.2 \mathrm{E}+3 \mathrm{x}+2.7 \mathrm{E}+5$ & 0.9912 \\
\hline & & & & \\
\hline
\end{tabular}




\section{Gaseous VOCs and Oxygenated VOCs}

Oxygenated VOCs (carbonyls) and VOC were simultaneously sampled on the field with the AEROVOCC device. On the one hand, the performances of VOC measurements in the gaseous and aqueous phases have been described in detail in Wang et al (2020) at the PUY station. The detection limits and the extended calculated uncertainties are reported in Table S6. On the other hand, the measurement of carbonyls in the gaseous phase has been adapted from Rossignol et al. (2012). The derivatization of gaseous carbonyls is directly performed on the solid Tenax ${ }^{\circledR}$ TA tubes after the atmospheric sampling. Before sampling, the Tenax sorbent is pre-coated at the laboratory. The sorbent coating is achieved during 20 min by sublimation of PFBHA: a nitrogen stream $\left(100 \mathrm{ml} \mathrm{min}^{-1}\right.$ tube $\left.^{-1}\right)$ is passed through a glass bulb that contains solid PFBHA and connected to 8 Tenax ${ }^{\circledR}$ sorbent tubes within an oven maintained at $110{ }^{\circ} \mathrm{C}$ (homemade device). A PFBHA mass of $300 \mu \mathrm{g}$ per connected tube is introduced into the glass bulb. After the coating process, the pre-coated tube is sealed and left at room temperature. The coating efficiency and quality (no contamination) have been tested by TD-GCMS. Humidity is recognized to modify the derivatization efficiency (Rossignol et al., 2012). The cloudy atmosphere usually presents high humidity levels, and its influence has been tested at the laboratory for PFBHA coated tubes. Except for formaldehyde, the responses of other carbonyls are not influenced by relative humidity levels $(0,50$, and $90 \%)$ within the determined repeatability range. In the case of $\mathrm{F}$, the peak area at $90 \%-\mathrm{RH}$ is two to three times higher at 50 and $90 \%$ $\mathrm{RH}$ than at $0 \%$. The breakthrough volume (BV) tests have been performed in real clear-sky atmospheric conditions with two Tenax PFBHA pre-coated tubes in series (the front and the back sampling tubes) and operated at a flow rate of 100

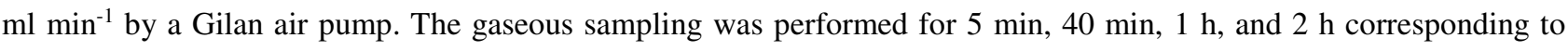
sampling volumes of $0.5 \mathrm{~L}, 4 \mathrm{~L}, 6 \mathrm{~L}$, and $12 \mathrm{~L}$, respectively at UCA (Clermont-Auvergne University) Cézeaux campus and the urban station of ATMO Auvergne Air Quality Network in Clermont-Ferrand. For a given compound, the breakthrough volume is reached when the response of the compound in the back sampling tube (or second coated tube) is higher than $5 \%$ of the one in the front tube. For the light carbonyl compound formaldehyde (F), the BV is always overpassed even at a small volume of 0.5 L. For C4-C5 carbonyls, C4-compounds breakthrough at $6 \mathrm{~L}$ while pentanal (C5) does not. Consequently, the determined concentrations of carbonyls lower than C5 are semi-quantitative: the measured concentrations of OVOC represent the lower limits. For the analytical curve of carbonyl compounds on-sorbenttube derivatization, a diluted $\mathrm{C}=\mathrm{O}$ standard solution of $2 \mu \mathrm{mol} \mathrm{L} \mathrm{L}^{-1}-10 \mathrm{mmol} \mathrm{L}-1$ is prepared with the carbonyl compound standards $\left(\mathrm{C}=\mathrm{O}\right.$ standard solution) prepared at $0.01 \mathrm{M}$ in $\mathrm{H}_{2} \mathrm{O} /$ acetonitrile (5/95). One $\mu \mathrm{L}$ of the diluted carbonyl standard solution is injected into every pre-conditioned Tenax ${ }^{\circledR}$ TA tubes pre-coated with PFBHA. These tubes are stored at room temperature for five-day-derivatization before TD-GC-MS analysis. The linearity of the method is good with $\mathrm{R}^{2}>95 \%$.

\section{VOCs in cloud water}

VOCs in cloud water were analysed using the method developed in Wang et al. (2020). Stir Bar Sorptive Extraction (SBSE) was used to pre-concentrate dissolved VOCs in cloud water. VOCs have been already detected and analysed by this method for different environmental media like river water, seawater, soil, food and flavour (Alves et al., 2005; Coelho et al., 2009; Tredoux et al., 2008), and recently in cloud waters at low concentrations (Wang et al., 2020).

SBSE is an application of stir bars coated with polydimethylsiloxane (PDMS), also called "Twisters". This equilibrium technique leads to the extraction of solutes from the aqueous phase to the PDMS phase, which is controlled by the partitioning coefficient of the solutes between the PDMS phase and the aqueous phase. The partitioning coefficient is usually approximated to the octanol-water partitioning coefficient $\mathrm{K}_{\mathrm{O} / \mathrm{w}}$. The extraction efficiency (E), which corresponds to the recovery of analytes from the samples, depends not only on the $\mathrm{K}_{\mathrm{O} / \mathrm{w}}$ but also on the volume of water and the 
volume of PDMS. At a given $\mathrm{K}_{\mathrm{O} / \mathrm{w}}$, a theoretical E can be determined from different volumes. In practice, other parameters are known to affect the solid-water equilibrium and the ex- traction efficiency as well (Kawaguchi et al., 2005; Ochiai et al., 2001; Pang et al., 2011; Portugal et al., 2008): extraction time, PDMS volume, sample volume and ionic strength. These factors have been optimized on modelled aqueous matrices in order to achieve optimal extraction of VOCs. Moreover, the thermo-desorption step by the TD/GC-MS was optimized to guarantee the complete transfer of the studied compounds from the twister to the GC column. Thermo-desorption conditions are the same as for cartridges, which allows a total desorption for extracted compounds by Twisters. The SBSE samples were then transferred into an empty cartridge following the same analytical procedure that the one described for gaseous samples. All the details about performances, methodology, optimisation, and uncertainties associated with the analytical techniques are fully described in the work of Wang et al. (2020). 
Table S6. Performances of VOC measurements in the gaseous and aqueous phases (Wang et al., 2020) and OVOC measurements in the gaseous phase. DL: detection limits in ng. UiI: extended uncertainty following the ACTRIS network procedure (Hoerger et al., 2015).

\begin{tabular}{|c|c|c|c|c|}
\hline Compounds & $\begin{array}{c}\text { DL by } \\
\text { SBSE } \\
\text { (ng) } \\
\end{array}$ & $\begin{array}{c}\text { DL by } \\
\text { Tenax® tube } \\
\text { (ng) } \\
\end{array}$ & $\mathbf{U}_{\mathrm{Ci}}(\%)$ in air & $\begin{array}{l}\mathrm{U}_{\mathrm{Ci}}(\%) \\
\text { in water }\end{array}$ \\
\hline \multicolumn{5}{|l|}{ VOC } \\
\hline Benzene & 0.019 & 0.65 & 19.6 & 11.8 \\
\hline Toluene & 0.005 & 0.13 & 17.4 & 10.2 \\
\hline Ethylbenzene & 0.018 & 0.34 & 17.4 & 16.0 \\
\hline m+p-xylene & 0.005 & 0.11 & 18.2 & 17.8 \\
\hline o-xylene & 0.014 & 0.25 & 17.0 & 16.2 \\
\hline Styrene & 0.026 & 0.46 & 17.0 & 16.6 \\
\hline Isopropylbenzene & 0.020 & 0.39 & 20.2 & 20.1 \\
\hline n-propylbenzene & 0.038 & 0.74 & 25.2 & 25.2 \\
\hline 1,3,5-trimethylbenzene & 0.010 & 0.19 & 23.0 & 23.0 \\
\hline 1,2,4-trimethylbenzene & 0.011 & 0.22 & 20.4 & 20.6 \\
\hline Naphtalene & 0.039 & 0.89 & 20.4 & 18.8 \\
\hline Isoprene & 0.014 & 0.67 & 22.2 & 20.4 \\
\hline$\alpha$-pinene & 0.044 & 0.95 & 19.4 & 19.4 \\
\hline$\beta$-pinene & 0.015 & 0.33 & 20.8 & 20.8 \\
\hline Limonene & 0.006 & 0.13 & 17.8 & 18.0 \\
\hline Nopinone & 0.027 & 0.60 & 17.2 & 19.6 \\
\hline \multicolumn{5}{|l|}{ OVOC } \\
\hline Methylvinylketone (MVK) & n.d. & 3.45 & n.d. & n.d. \\
\hline Metacrolein (MACR) & n.d. & 3.40 & n.d. & n.d. \\
\hline Butanal & n.d. & 3.26 & n.d. & n.d. \\
\hline Pentanal & n.d. & 3.22 & n.d. & n.d. \\
\hline Hexanal & n.d. & 3.26 & n.d. & n.d. \\
\hline Hydroxyacetone & n.d. & 4.32 & n.d. & n.d. \\
\hline Heptanal & n.d. & 3.40 & n.d. & n.d. \\
\hline Octanal & n.d. & 3.28 & n.d. & n.d. \\
\hline Formaldehyde $(\mathrm{F})$ & n.d. & 0.44 & n.d. & n.d. \\
\hline Acetone (AC) & n.d. & 3.16 & n.d. & n.d. \\
\hline Glyoxal (GL) & n.d. & 2.04 & n.d. & n.d. \\
\hline Methylglyoxal (MGL) & n.d. & 4.68 & n.d. & n.d. \\
\hline
\end{tabular}

n.d.= non determined. 

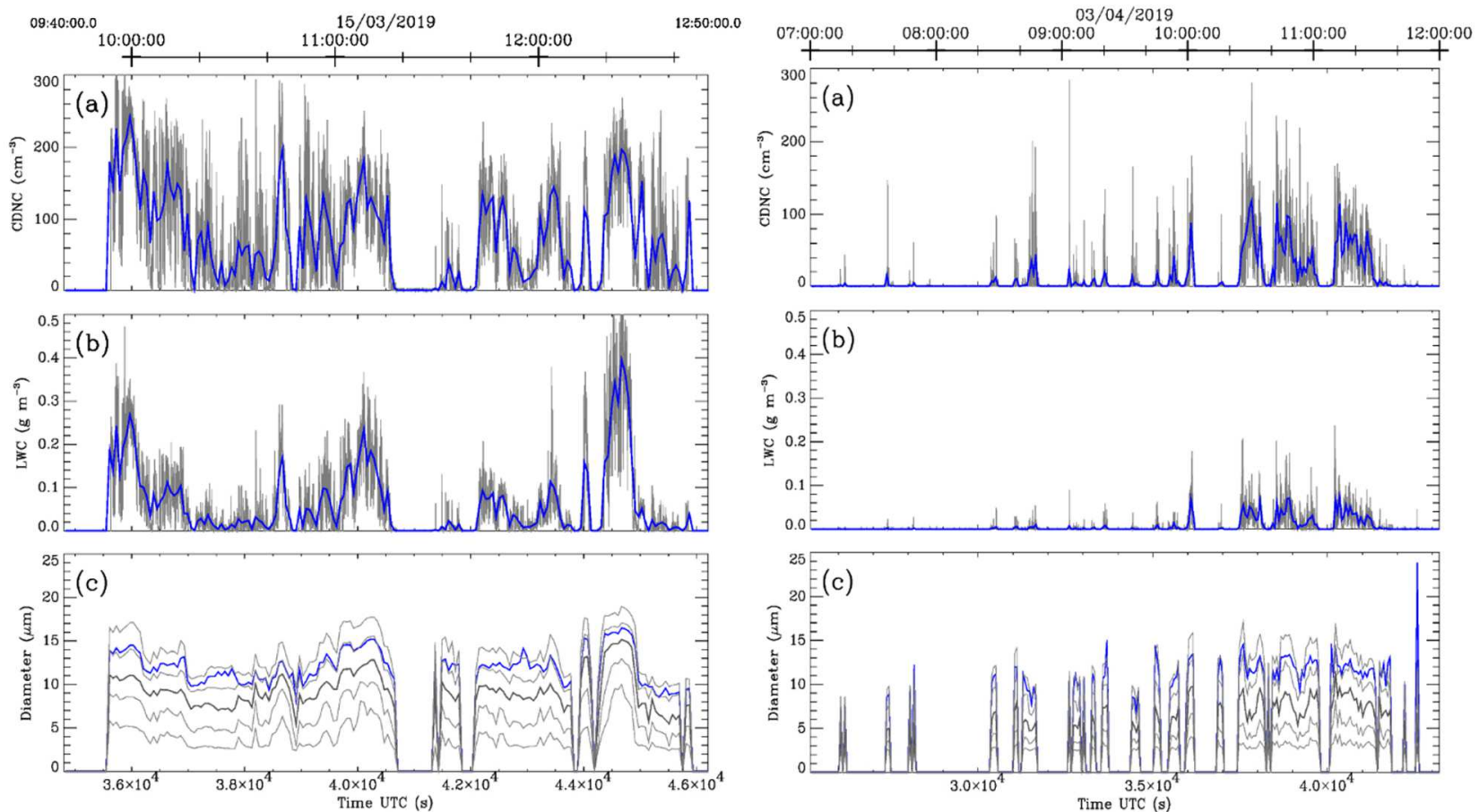

Figure S2. Time series of one minute average cloud microphysical properties derived from the CDP measurements during cloud $R 2$ (on the left) and cloud R13 (on the right): a) cloud droplet number concentration (CDNC), b) liquid water content (LWC), and c) effective diameter (blue), median (dark grey) and percentiles $\left(10^{\text {th }}, 25^{\text {th }}, \mathbf{7 5}^{\text {th }}\right.$ and $90^{\text {th }}$, light grey) of the droplet size distribution. For panels a) and b) $1 \mathrm{~Hz}$ measurements are superimposed (grey). 

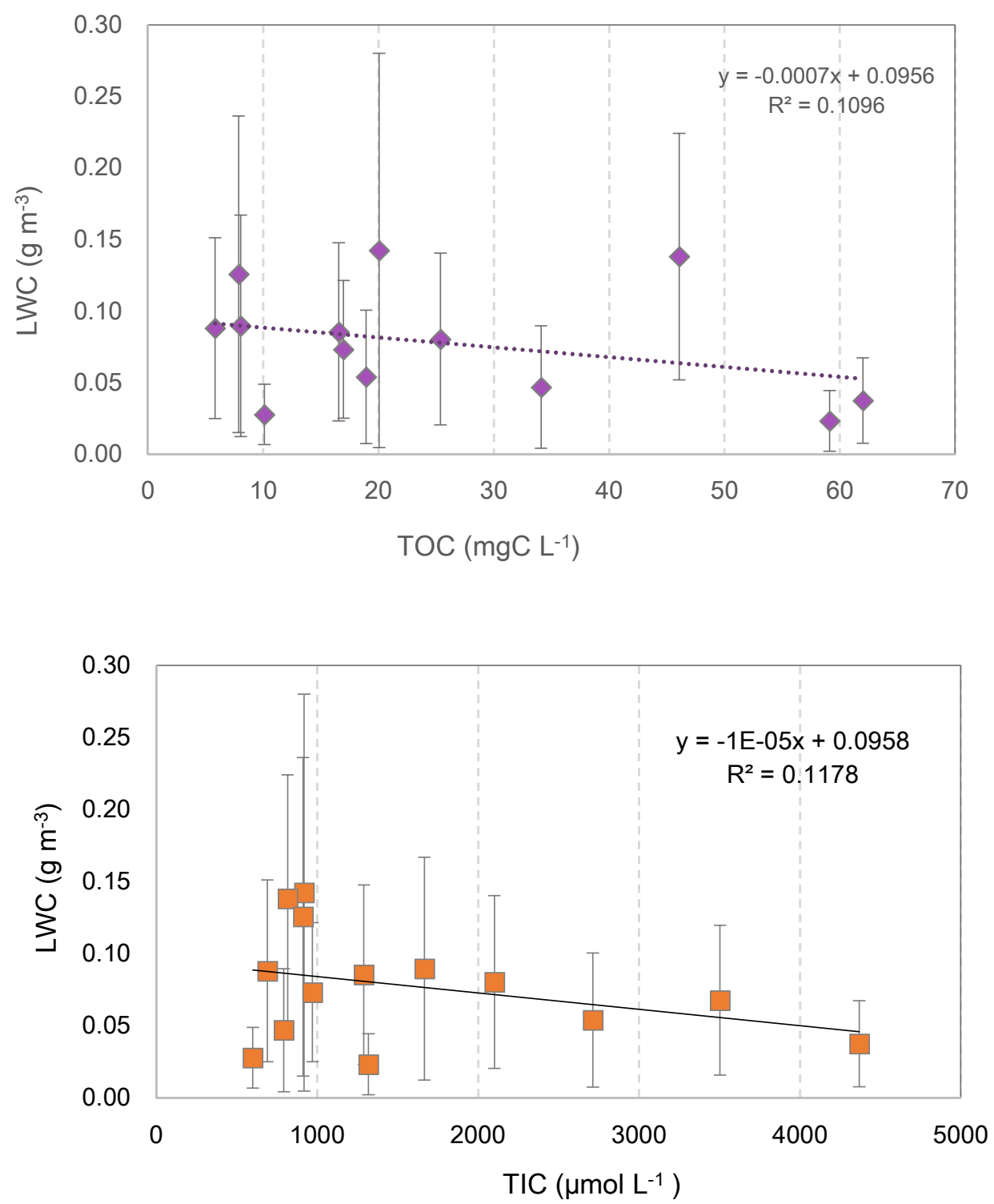

Figure S3. Scatter plots of LWC content $v$ s total organic carbon (TOC) and total ionic content (TIC) resulted as the sum of ions obtained for all the cloud events during BIO-MAÏDO. 

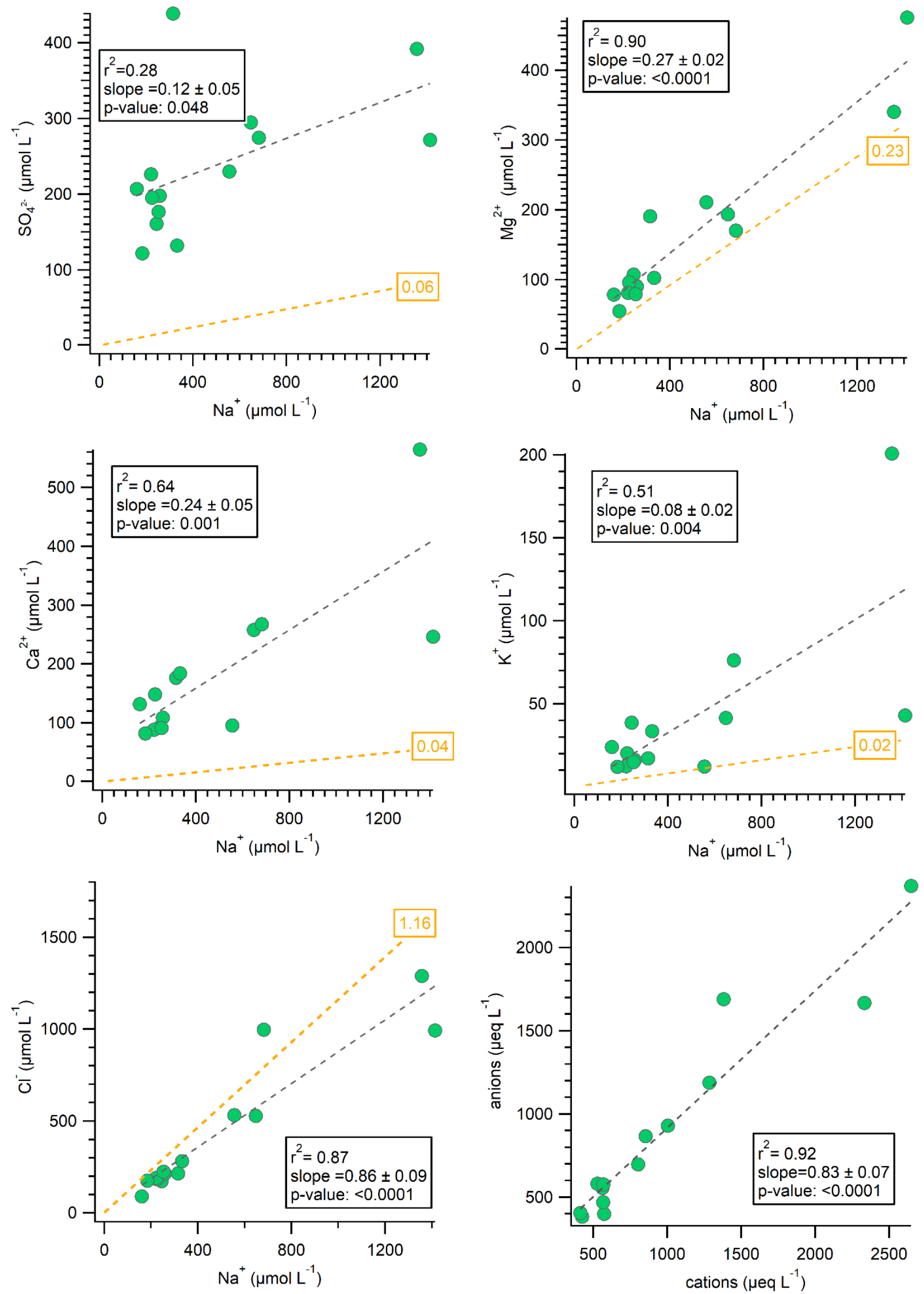

Figure S4. Correlations of observed ions and charge equilibrium for all the cloud samples obtained at Reunion Island. Grey dashed lines represent the linear fit of the data and yellow dashed lines show the seawater ratio obtained from the literature (Benedict et al., 2012). 


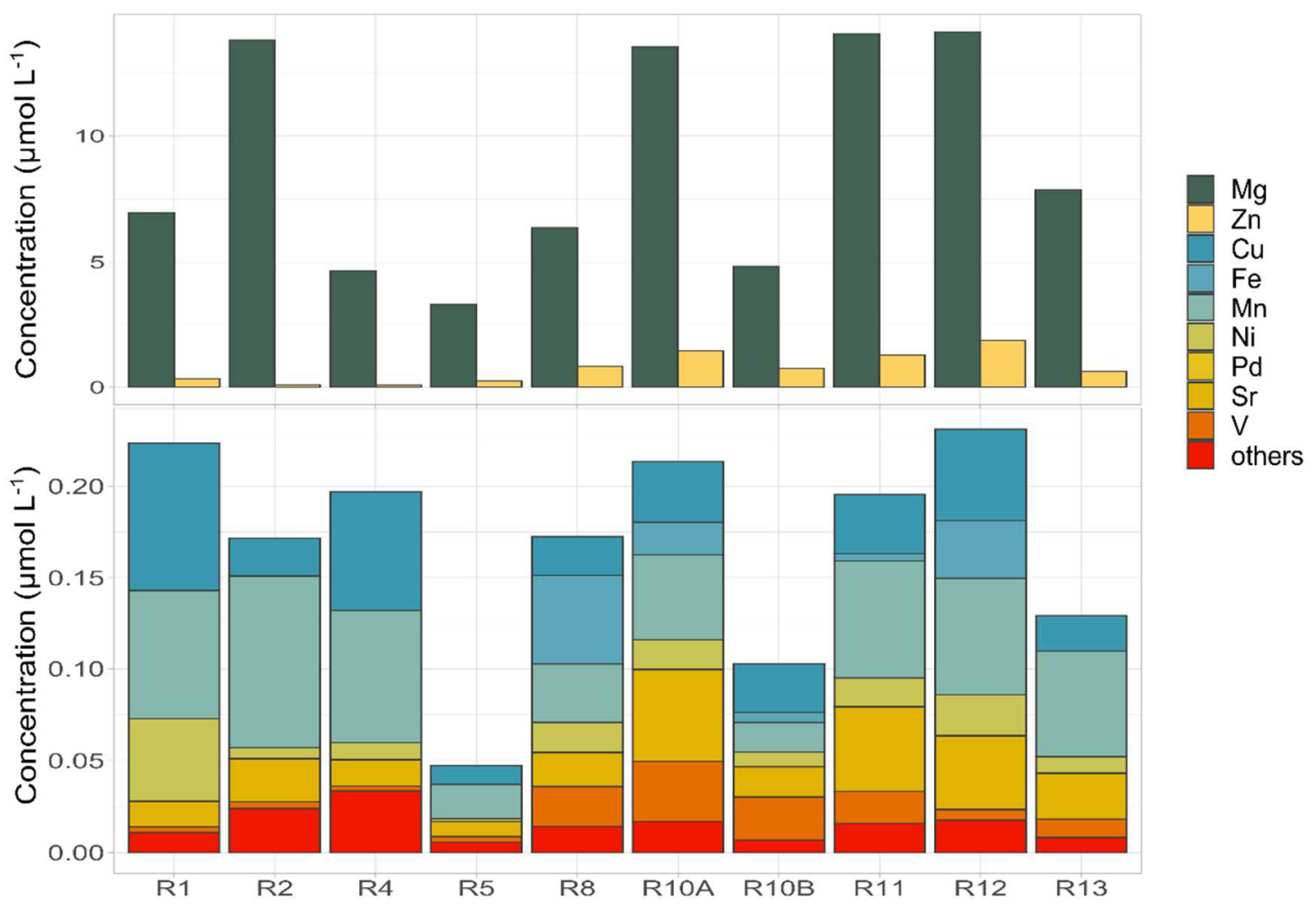

Figure S5. Trace metal concentrations observed in each cloud event separated by concentration range in a) magnesium and zinc and b) cupper, iron, manganese, nickel, lead, strontium, vanadium and other trace metal concentrations. R1 to R13 refer to individual cloud samples. 


\section{Hydrogen Peroxide quantification}

$\mathrm{H}_{2} \mathrm{O}_{2}$ levels are examined on 12 clouds of this study (Figure S6). This oxidant dissolves from the gas phase to the aqueous phase (main source) (McElroy, 1986; Xuan et al., 2020) but it can also be produced through aqueous phase chemistry (Mouchel-Vallon et al., 2017). Concentrations of gaseous $\mathrm{H}_{2} \mathrm{O}_{2}$ have been reported in few studies in the last years (Fischer et al., 2015; Junkermann and Stockwell, 1999; O'Sullivan et al., 1999; Weller et al., 2000). These studies have shown a latitudinal variation of $\mathrm{H}_{2} \mathrm{O}_{2}$ concentrations with higher values observed in the tropics (>500 ppt) and decreasing when the latitude increase in both hemispheres (reaching $\sim 250 \mathrm{ppt}$ at $40^{\circ}$ of the southern hemisphere) (Fischer et al., 2015). The $\mathrm{H}_{2} \mathrm{O}_{2}$ aqueous phase photo-reactivity is particularly suspected to produce hydroxyl radicals through its photolysis and its reactivity with iron (Fenton processes) (Bianco et al., 2015, 2020), contributing by this way to the oxidative capacity of cloud droplets. Measured values indicated in this study could be biased due to the storage of samples and so should be carefully analysed. Values range from 0.04 to $8.79 \mu \mathrm{mol} \mathrm{L}{ }^{-1}$ with an average value of $1.94 \pm 2.57 \mu \mathrm{mol} \mathrm{L}^{-1}$ and are surely underestimated. However, those values are interesting since they highlight high variability among the samples indicating different photochemical equilibrium. Globally, we can notice that $\mathrm{H}_{2} \mathrm{O}_{2}$ concentrations are in the range of previous studies performed on various environmental conditions (Deguillaume et al., 2014; Marinoni et al., 2004; Valverde-Canossa et al., 2005).

We have assessed the correlation between hydrogen peroxide and the non-sea salt of sulphate fraction. A good determination coefficient of $\mathrm{r}^{2}=0.60$ was obtained indicating a possible relationship between $\mathrm{H}_{2} \mathrm{O}_{2}$ and sulphate aqueous production. Additionally, a positive moderate correlation $\left(\mathrm{r}^{2}=0.53\right)$ was observed between $\mathrm{H}_{2} \mathrm{O}_{2}$ and total dissolved organic carbon. This relationship could be used as a proxy for the gas-phase VOC concentration and gas-phase production of $\mathrm{H}_{2} \mathrm{O}_{2}$ since it can be probably produced at high $\mathrm{VOC} / \mathrm{NO}_{\mathrm{x}}$ ratios as a result of peroxy radical termination reactions (Benedict et al., 2012). 

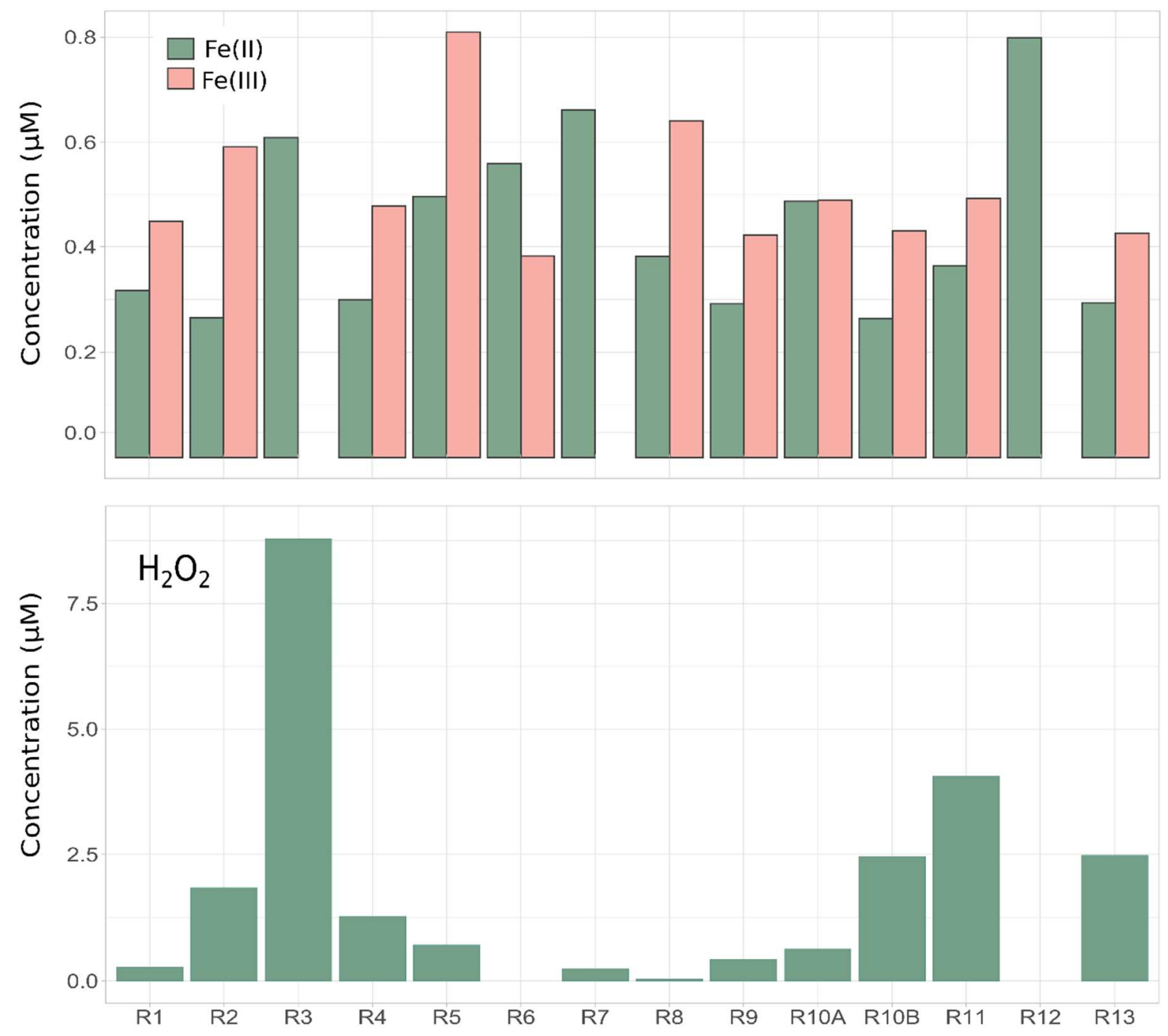

Figure S6. Iron species and hydrogen peroxide concentrations observed in each cloud sample during BIO-MAÏDO. 


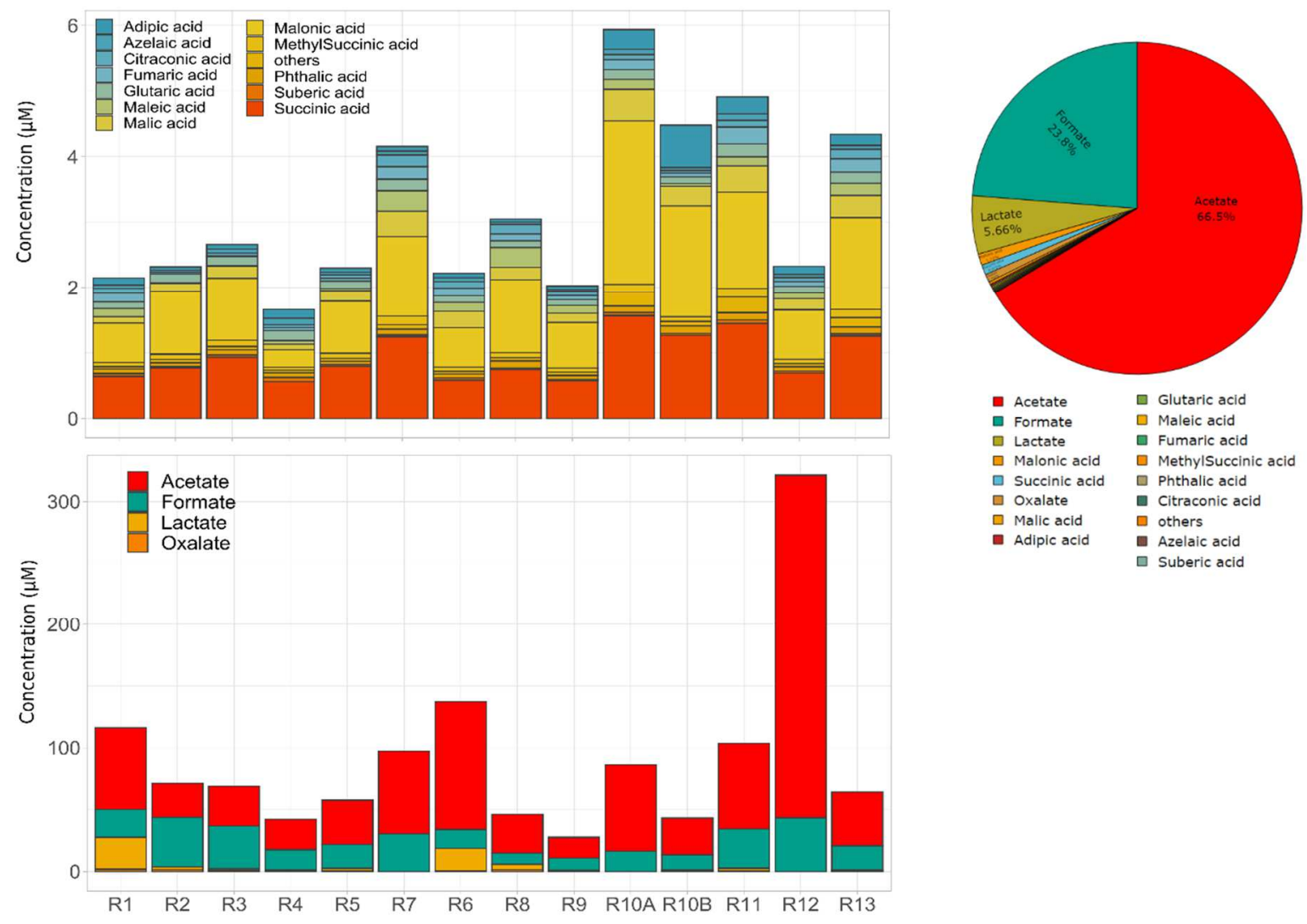

Figure S7. Concentrations of carboxylic acids and the total average relative contribution observed on cloud samples during BIO-MAÏDO campaign. R1 to $\mathrm{R} 13$ refer to individual cloud samples. 


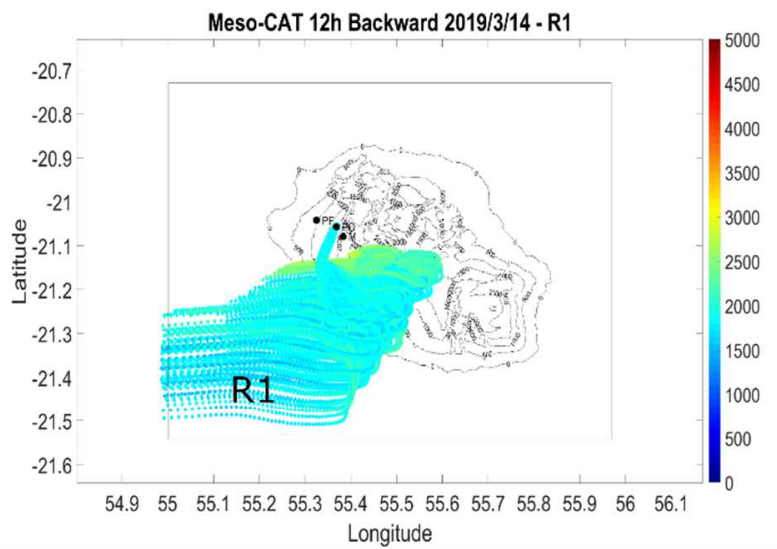

Meso-CAT 12h Backward 2019/3/18 - R3

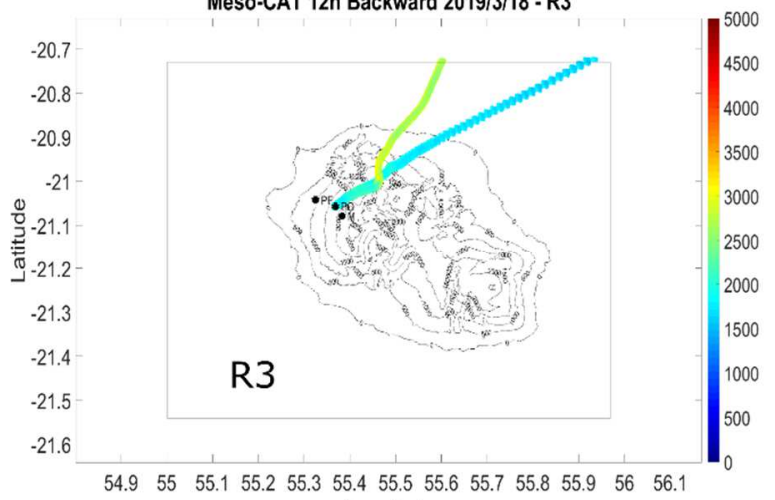
Longitude

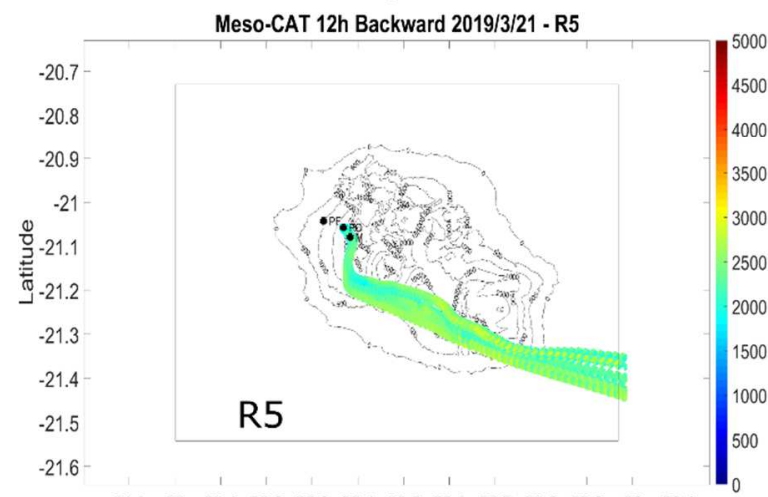

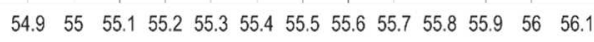
Longitude
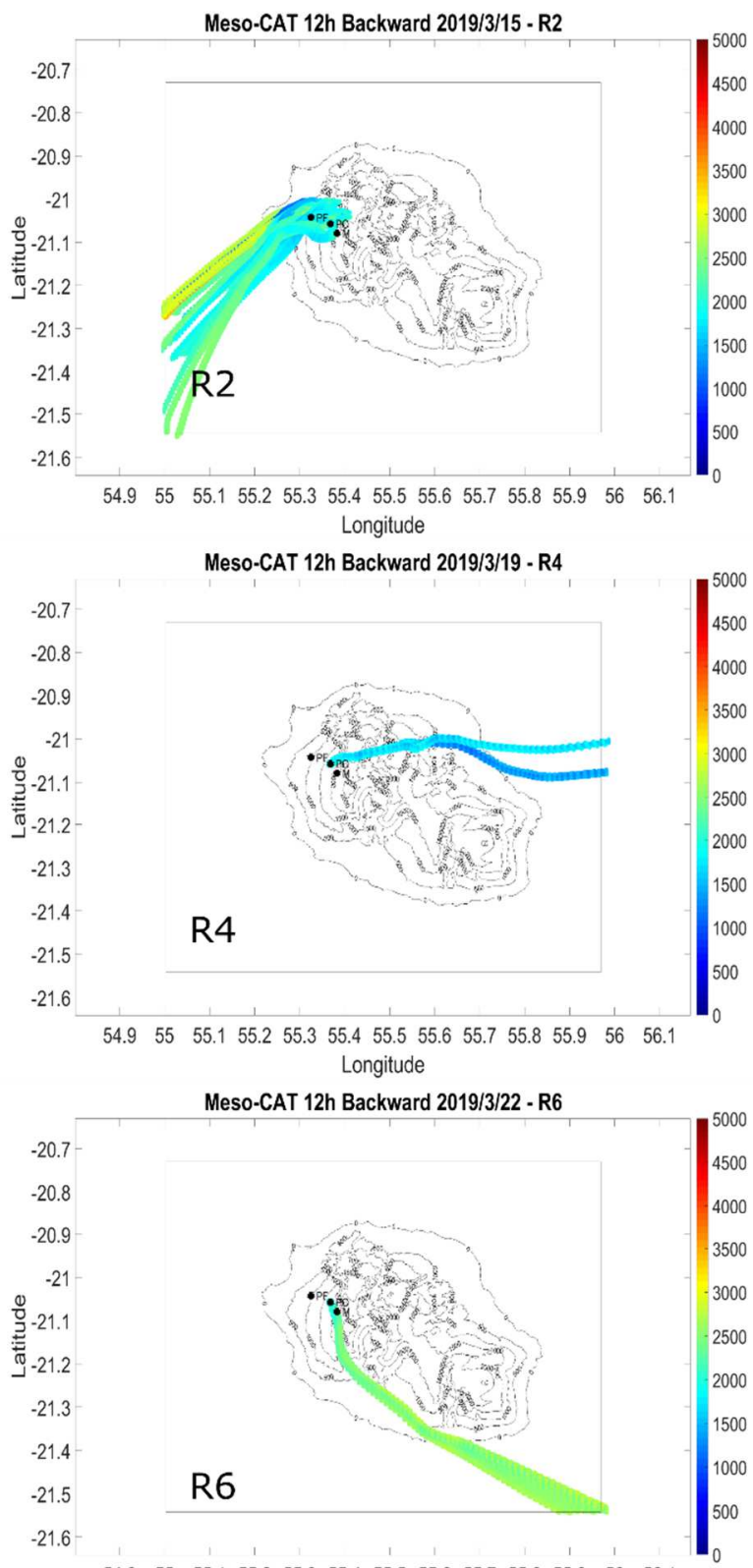

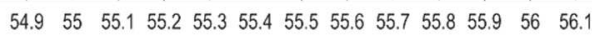
Longitude

Figure S8. Back trajectories obtained for each cloud event (R1 to R6). 


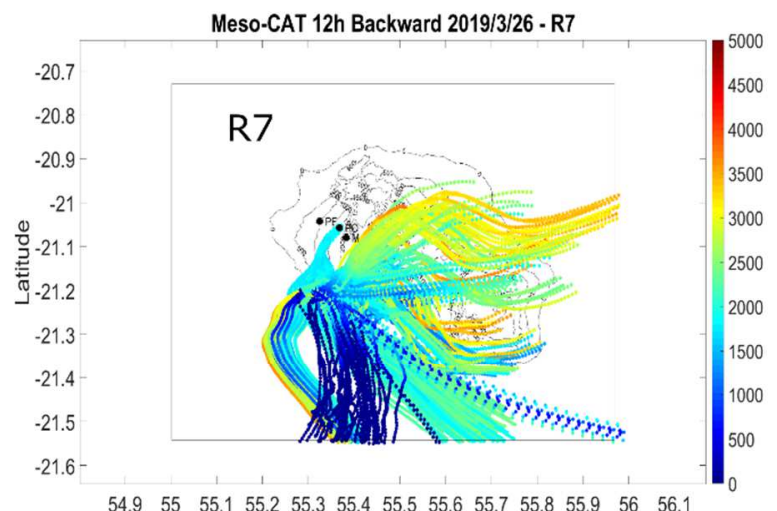

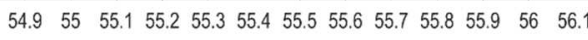
Longitude

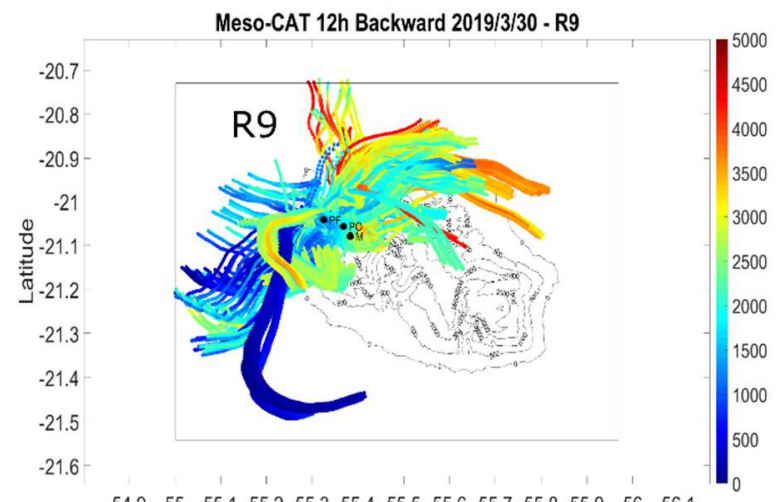

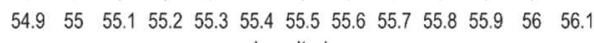
Longitude

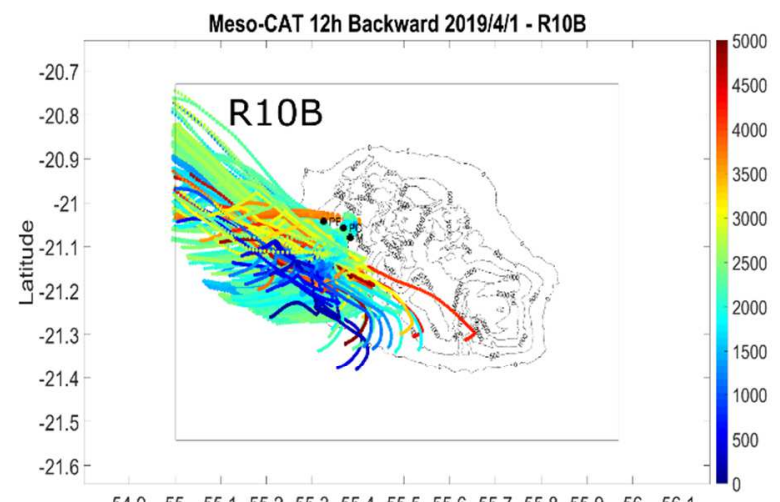

$\begin{array}{lllllllllllll}54.9 & 55 & 55.1 & 55.2 & 55.3 & 55.4 & 55.5 & 55.6 & 55.7 & 55.8 & 55.9 & 56 & 56.1\end{array}$ Longitude

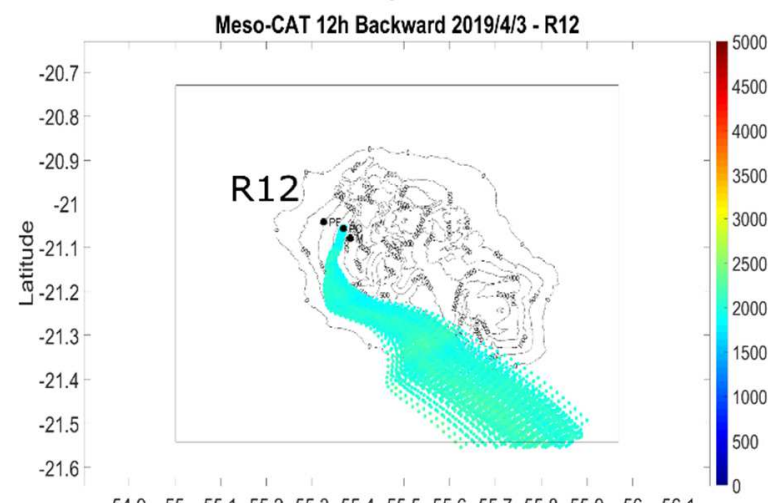

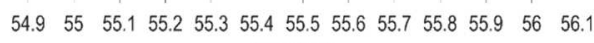
Longitude

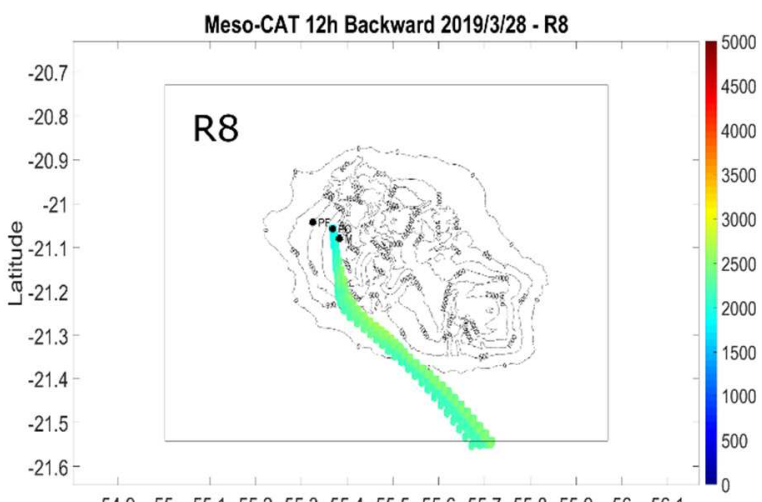

$\begin{array}{lllllllllllll}54.9 & 55 & 55.1 & 55.2 & 55.3 & 55.4 & 55.5 & 55.6 & 55.7 & 55.8 & 55.9 & 56 & 56.1\end{array}$ Longitude

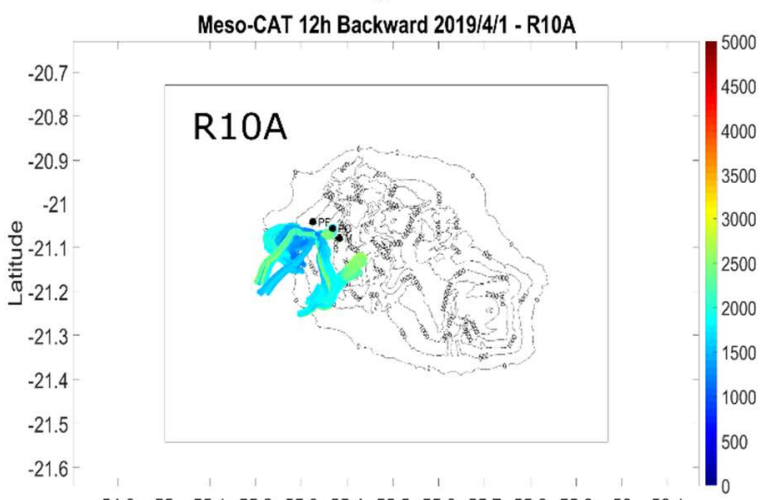

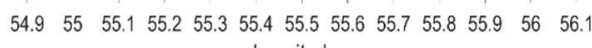
Longitude

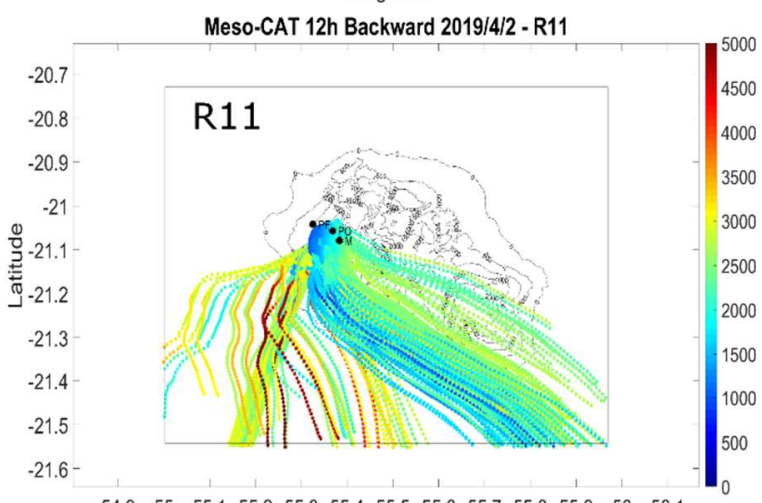
$\begin{array}{ccccccccc}54.9 & 55 \quad 55.155 .255 .355 .455 .555 .655 .755 .8 & 55.9 \quad 56 \quad 56.1 \\ \text { Longitude }\end{array}$

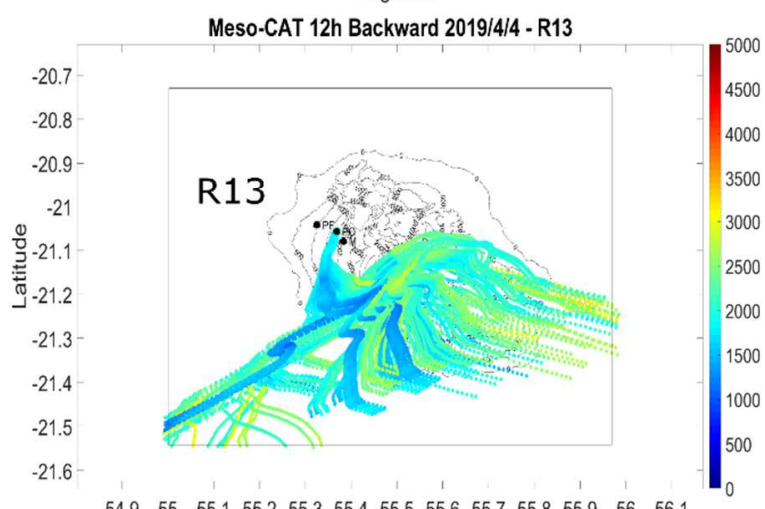

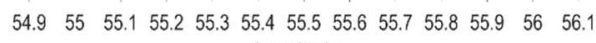
Longitude

Figure S8. (Continuation). Back trajectories obtained for each cloud event (R7 to R13). 


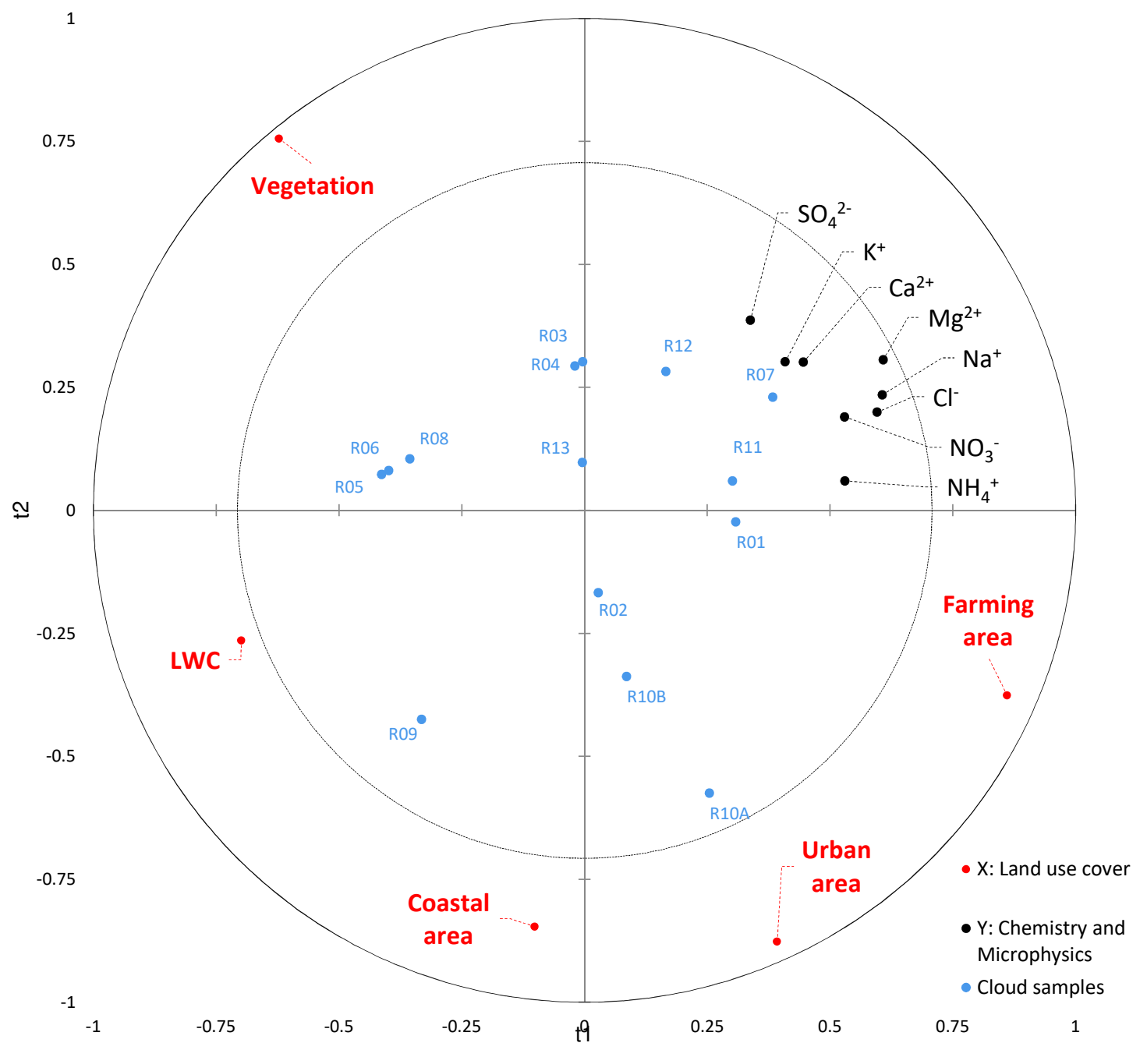

Figure S9. Correlations between chemical species and land use cover obtained by Partial least squares (PLS) analysis for all the sampled clouds. The correlations map with $t$ component on axes $t 1$ and $t 2$ superimposes the "Xs", the "Ys" and the cloud events. The dependent variables (Ys) from the chemical matrix are displayed in black; the explanatory variables from the "land use cover" matrix and the LWC are displayed in red. The 13 cloud samples are indicated in blue. 


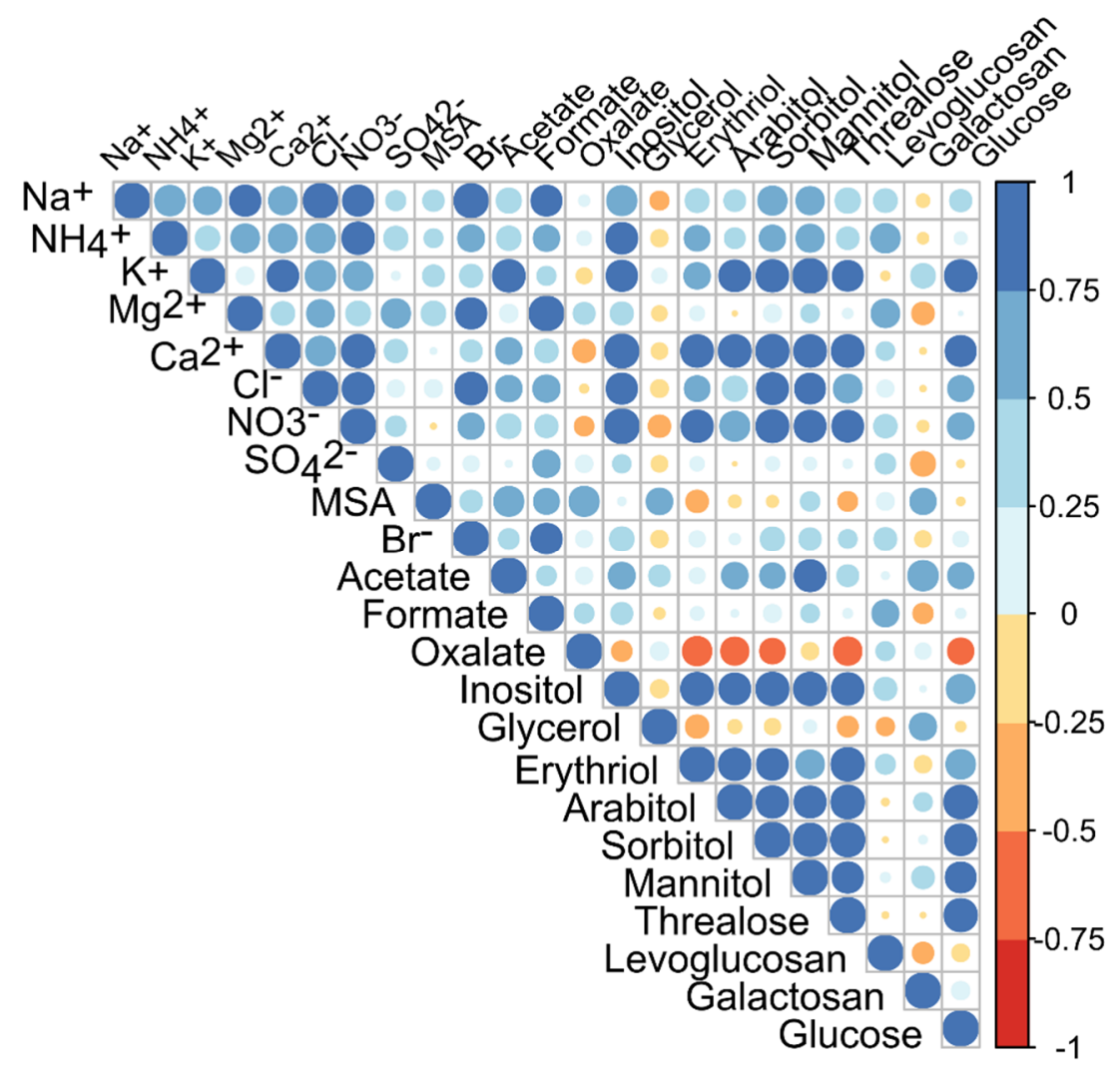

Figure S10. Correlation matrix of sugars, ions, and light acids observed on fourteen cloud samples at La Reunion Island. Colours represent the Pearson correlation coefficient ( $r$ ) between species, being red-orange colours anti-correlated and blue colours positively correlated. The size of the circle is proportional to the correlation coefficients. 


\section{Amino Acid groups}

Hydrophilic

Neutral

Hydrophobic

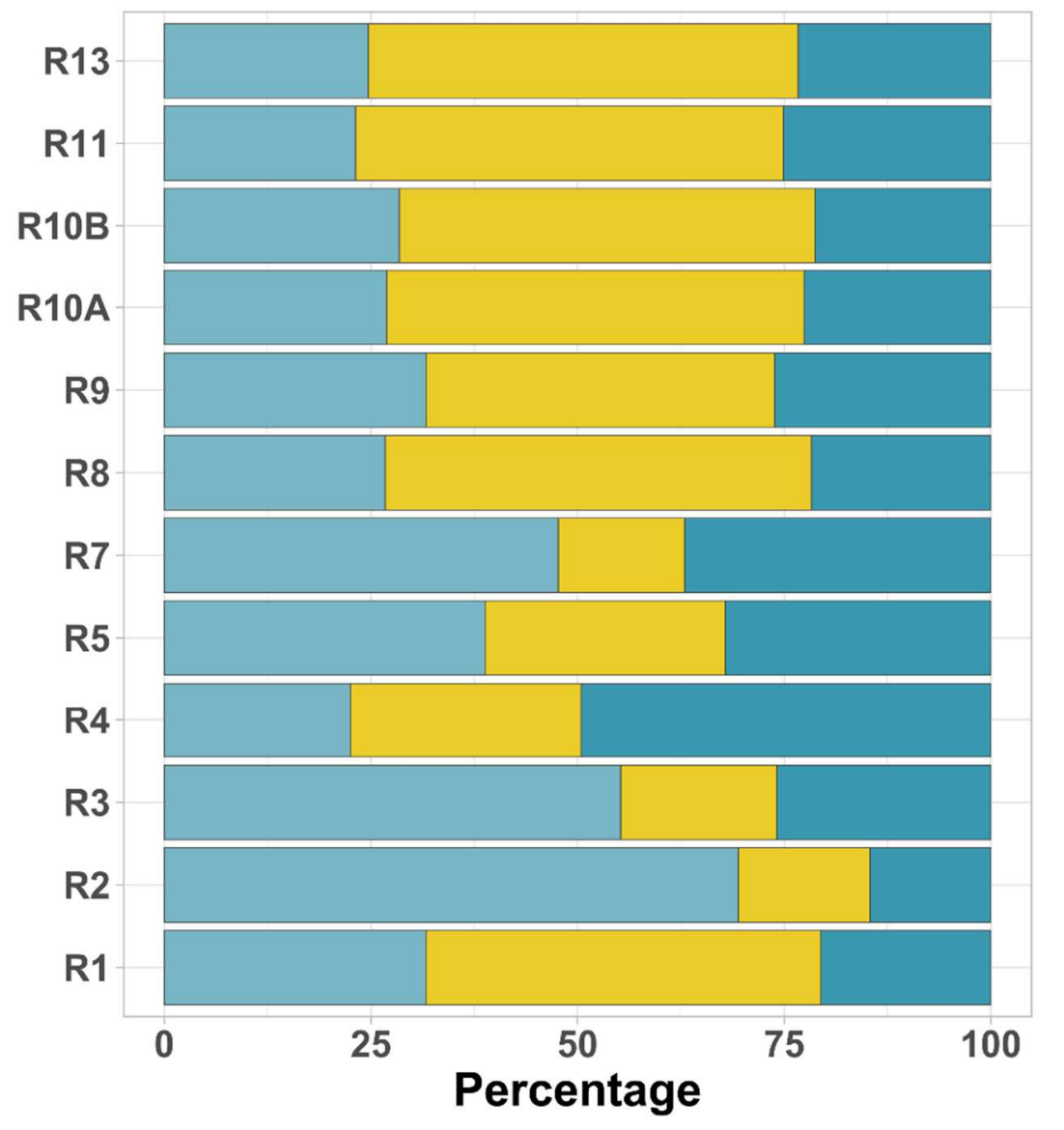

Figure S11. Relative composition of amino acids grouped by hydropathy index observed in each cloud sample. 


\section{Partitioning coefficient " $q$ "}

Chemical compounds are partitioned between the gas and aqueous phases which can be represented by a partitioning coefficient q, defined by Audiffren et al. (1998) and used in other studies such as in van Pinxteren et al. (2005) and Wang et al. (2020) which is defined as:

$$
q=\frac{C_{a q}}{L W C \times H_{e f f} \times R \times T \times C_{g a s}}
$$

where $\mathrm{C}_{\mathrm{aq}}$ and $\mathrm{C}_{\mathrm{gas}}$ are, respectively, the aqueous and gaseous concentrations of the compound of interest in molec $\mathrm{cm}^{-3}$, the LWC liquid water content of the cloud event in vol / vol. $\mathrm{H}_{\text {eff }}$ is the effective Henry's law constant in $\mathrm{mol} \mathrm{L}^{-1} \mathrm{~atm}^{-1}$ and $\mathrm{R}=$ 0.08206 atm $\mathrm{M}^{-1} \mathrm{~K}^{-1}$. The $\mathrm{q}$ factor indicates whether the compound of interest is at Henry's law equilibrium $(\mathrm{q}=1)$, unsaturated $(q<1)$ or supersaturated in the aqueous phase $(q>1)$.

Tables S7 and S8 present the values of gas and aqueous phase concentrations and $\mathrm{H}_{\text {eff }}$ values of each VOC analyse, together with temperature and LWC values measured during each cloud event during this study.

Table S7. Concentrations of gas-phase volatile organic compounds observed during cloud events at Reunion Island and used for the partitioning coefficient calculations.

\begin{tabular}{|c|c|c|c|c|c|c|c|c|c|c|c|}
\hline \multicolumn{2}{|r|}{ Cloud } & $\mathbf{R 1}$ & $\mathbf{R 3}$ & R4 & R5 & R6 & $\mathbf{R 8}$ & R9 & R10B & R11 & R13 \\
\hline \multirow{4}{*}{$\begin{array}{l}\text { Gas- } \\
\text { phase } \\
\text { (ppb) }\end{array}$} & Formaldehyde & n.d. & 1.481 & 1.967 & 13.6 & 2.051 & 4.096 & 1.649 & 0.733 & n.d. & n.d. \\
\hline & Acetone & n.d. & 0.278 & $<\mathrm{DL}$ & 0.645 & 2.093 & 3.408 & 0.37 & 0.599 & n.d. & n.d. \\
\hline & Glyoxal & n.d. & 0.044 & 0.13 & $<\mathrm{DL}$ & $<\mathrm{DL}$ & 0.005 & 0.01 & 0.011 & n.d. & n.d. \\
\hline & Methylglyoxal & n.d. & 0.048 & 0.098 & $<\mathrm{DL}$ & $<\mathrm{DL}$ & 0.001 & 0.002 & 0.001 & n.d. & n.d. \\
\hline \multirow{9}{*}{$\begin{array}{l}\text { Gas- } \\
\text { phase } \\
\text { (ppt) }\end{array}$} & Benzene & 187.40 & n.d. & n.d. & n.d. & 195.52 & 771.18 & 150.81 & 157.09 & 67.44 & 105.60 \\
\hline & Toluene & 92.73 & n.d. & n.d. & n.d. & 392.91 & 350.89 & 146.17 & 151.38 & 56.72 & 350.61 \\
\hline & Ethylbenzene & 59.18 & n.d. & n.d. & n.d. & 69.69 & 45.79 & 23.28 & 14.33 & 4.89 & 50.33 \\
\hline & $\mathrm{m}+\mathrm{p}$-xylene & 29.55 & n.d. & n.d. & n.d. & 144.06 & 145.62 & 38.93 & 26.43 & 22.72 & 56.99 \\
\hline & o-xylene & 16.04 & n.d. & n.d. & n.d. & 44.16 & 47.33 & 12.90 & 20.77 & 6.72 & 17.13 \\
\hline & Isoprene & 19.50 & n.d. & n.d. & n.d. & 172.25 & 243.21 & 115.56 & 4.05 & 128.20 & 81.83 \\
\hline & $\alpha$-pinene & 20.21 & n.d. & n.d. & n.d. & 56.37 & 41.10 & 37.39 & 43.62 & 12.60 & 46.45 \\
\hline & $\beta$-pinene & 4.30 & n.d. & n.d. & n.d. & 6.66 & 5.56 & 5.05 & 3.46 & 1.56 & 5.91 \\
\hline & Limonene & 11.10 & n.d. & n.d. & n.d. & 23.63 & 79.38 & 14.04 & 11.07 & 8.26 & 26.54 \\
\hline
\end{tabular}


Table S8. Gas-phase and aqueous-phase concentrations, temperature, LWC and Henry effective constants used for the calculation of $q$ factors. Heff are obtained from Sander (2015) and Wang et al. (2020) considering the intrinsic Henry's law constant and the hydration constants for carbonyls.

\begin{tabular}{|c|c|c|c|c|c|c|c|}
\hline \multirow[t]{2}{*}{ Compound } & \multirow[t]{2}{*}{ Cloud } & $\begin{array}{c}\text { Gas phase } \\
\text { concentration }\end{array}$ & $\begin{array}{l}\text { Aqueous phase } \\
\text { concentration }\end{array}$ & $\mathbf{T}$ & LWC & $\begin{array}{c}\text { Heff }_{\text {ef }} \mathbf{T} \text { cloud } \\
\text { event })\end{array}$ & $q$ factor \\
\hline & & molec $\mathrm{cm}^{-3}$ & molec $\mathrm{cm}^{-3}$ & $\left({ }^{\circ} \mathbf{C}\right)$ & $\mathrm{g} \mathrm{cm}^{-3}$ & & \\
\hline \multirow{10}{*}{ Isoprene } & \multirow{2}{*}{$\begin{array}{l}\text { R1 } \\
\text { R2 }\end{array}$} & $4.14 \mathrm{E}+08$ & $1.01 \mathrm{E}+06$ & 15.1 & 0.047 & $2.304 \mathrm{E}-01$ & $5.39 \mathrm{E}+03$ \\
\hline & & & $1.00 \mathrm{E}+06$ & 17 & 0.09 & $2.094 \mathrm{E}-01$ & \\
\hline & $\mathbf{R 5}$ & & $1.70 \mathrm{E}+06$ & 17 & 0.143 & 2.094E-01 & \\
\hline & R6 & $3.30 \mathrm{E}+09$ & & 17 & 0.138 & $2.094 \mathrm{E}-01$ & \\
\hline & $\mathbf{R 7}$ & & $1.47 \mathrm{E}+06$ & 17 & 0.068 & $2.094 \mathrm{E}-01$ & \\
\hline & \multirow{2}{*}{$\begin{array}{l}\text { R8 } \\
\text { R9 }\end{array}$} & $3.79 \mathrm{E}+09$ & $3.09 \mathrm{E}+06$ & 17.5 & 0.126 & $2.042 \mathrm{E}-01$ & $7.67 \mathrm{E}+02$ \\
\hline & & $2.68 \mathrm{E}+09$ & $1.63 \mathrm{E}+06$ & 17.2 & 0.088 & $2.073 \mathrm{E}-01$ & $8.21 \mathrm{E}+02$ \\
\hline & \multirow{2}{*}{$\begin{array}{c}\text { R10B } \\
\text { R11 }\end{array}$} & & $2.16 \mathrm{E}+06$ & 16.6 & 0.073 & $2.136 \mathrm{E}-01$ & \\
\hline & & $4.26 \mathrm{E}+09$ & $7.57 \mathrm{E}+05$ & 17.2 & 0.054 & $2.073 \mathrm{E}-01$ & $3.85 \mathrm{E}+02$ \\
\hline & R13 & $9.34 \mathrm{E}+08$ & $2.84 \mathrm{E}+06$ & 17.2 & 0.086 & $2.073 \mathrm{E}-01$ & $4.14 \mathrm{E}+03$ \\
\hline \multirow{10}{*}{$\alpha$-pinene } & \multirow{5}{*}{$\begin{array}{l}\text { R1 } \\
\text { R2 } \\
\text { R5 } \\
\text { R6 } \\
\text { R7 }\end{array}$} & $8.15 \mathrm{E}+08$ & $3.18 \mathrm{E}+04$ & 15.1 & 0.047 & $7.902 \mathrm{E}-03$ & $4.44 \mathrm{E}+03$ \\
\hline & & & $1.11 \mathrm{E}+05$ & 17 & 0.09 & $7.150 \mathrm{E}-03$ & \\
\hline & & & $1.46 \mathrm{E}+04$ & 17 & 0.143 & $7.150 \mathrm{E}-03$ & \\
\hline & & $1.13 \mathrm{E}+09$ & $2.88 \mathrm{E}+04$ & 17 & 0.138 & $7.150 \mathrm{E}-03$ & $1.08 \mathrm{E}+03$ \\
\hline & & & $5.76 \mathrm{E}+04$ & 17 & 0.068 & $7.150 \mathrm{E}-03$ & \\
\hline & \multirow{2}{*}{$\begin{array}{l}\text { R8 } \\
\text { R9 }\end{array}$} & $5.56 \mathrm{E}+08$ & $3.67 \mathrm{E}+04$ & 17.5 & 0.126 & $6.966 \mathrm{E}-03$ & $3.15 \mathrm{E}+03$ \\
\hline & & $1.09 \mathrm{E}+09$ & $3.78 \mathrm{E}+06$ & 17.2 & 0.088 & $7.076 \mathrm{E}-03$ & $2.33 \mathrm{E}+05$ \\
\hline & \multirow{2}{*}{$\begin{array}{c}\text { R10B } \\
\text { R11 }\end{array}$} & $8.95 \mathrm{E}+08$ & $8.84 \mathrm{E}+04$ & 16.6 & 0.073 & $7.302 \mathrm{E}-03$ & $7.80 \mathrm{E}+03$ \\
\hline & & $8.32 \mathrm{E}+07$ & $3.37 \mathrm{E}+03$ & 17.2 & 0.054 & $7.076 \mathrm{E}-03$ & $4.45 \mathrm{E}+03$ \\
\hline & R13 & $2.48 \mathrm{E}+07$ & $3.88 \mathrm{E}+04$ & 17.2 & 0.086 & $7.076 \mathrm{E}-03$ & $1.08 \mathrm{E}+05$ \\
\hline \multirow{10}{*}{$\beta$-pinene } & \multirow{10}{*}{$\begin{array}{c}\text { R1 } \\
\text { R2 } \\
\text { R5 } \\
\text { R6 } \\
\text { R7 } \\
\text { R8 } \\
\text { R9 } \\
\text { R10B } \\
\text { R11 } \\
\text { R13 }\end{array}$} & $8.86 \mathrm{E}+07$ & $2.38 \mathrm{E}+04$ & 15.1 & 0.047 & $2.519 \mathrm{E}-02$ & $9.60 \mathrm{E}+03$ \\
\hline & & & $7.88 \mathrm{E}+04$ & 17 & 0.09 & $2.274 \mathrm{E}-02$ & \\
\hline & & & & 17 & 0.143 & $2.274 \mathrm{E}-02$ & \\
\hline & & $1.34 \mathrm{E}+08$ & & 17 & 0.138 & $2.274 \mathrm{E}-02$ & \\
\hline & & & $4.10 \mathrm{E}+04$ & 17 & 0.068 & $2.274 \mathrm{E}-02$ & \\
\hline & & $5.30 \mathrm{E}+07$ & & 17.5 & 0.126 & $2.214 \mathrm{E}-02$ & \\
\hline & & $1.32 \mathrm{E}+08$ & $2.11 \mathrm{E}+06$ & 17.2 & 0.088 & $2.250 \mathrm{E}-02$ & $3.41 \mathrm{E}+05$ \\
\hline & & $7.09 \mathrm{E}+07$ & $5.92 \mathrm{E}+04$ & 16.6 & 0.073 & $2.323 \mathrm{E}-02$ & $2.07 \mathrm{E}+04$ \\
\hline & & $7.15 \mathrm{E}+06$ & & 17.2 & 0.054 & $2.250 \mathrm{E}-02$ & \\
\hline & & $9.11 \mathrm{E}+05$ & $9.60 \mathrm{E}+03$ & 17.2 & 0.086 & $2.250 \mathrm{E}-02$ & $2.29 \mathrm{E}+05$ \\
\hline \multirow{10}{*}{ Limonene } & \multirow{2}{*}{$\begin{array}{l}\text { R1 } \\
\text { R2 }\end{array}$} & $2.29 \mathrm{E}+08$ & $1.04 \mathrm{E}+05$ & 15.1 & 0.047 & $8.344 \mathrm{E}-02$ & $4.89 \mathrm{E}+03$ \\
\hline & & & $1.95 \mathrm{E}+05$ & 17 & 0.09 & $7.482 \mathrm{E}-02$ & \\
\hline & R5 & & $7.84 \mathrm{E}+04$ & 17 & 0.143 & 7.482E-02 & \\
\hline & R6 & $3.75 \mathrm{E}+08$ & $4.12 \mathrm{E}+04$ & 17 & 0.138 & $7.482 \mathrm{E}-02$ & $4.47 \mathrm{E}+02$ \\
\hline & $\mathbf{R 7}$ & & $1.38 \mathrm{E}+05$ & 17 & 0.068 & 7.482E-02 & \\
\hline & R8 & $6.04 \mathrm{E}+08$ & $4.13 \mathrm{E}+04$ & 17.5 & 0.126 & $7.272 \mathrm{E}-02$ & $3.13 \mathrm{E}+02$ \\
\hline & \multirow{2}{*}{$\begin{array}{c}\text { R9 } \\
\text { R10B }\end{array}$} & $3.79 \mathrm{E}+08$ & $2.03 \mathrm{E}+06$ & 17.2 & 0.088 & $7.397 \mathrm{E}-02$ & $3.46 \mathrm{E}+04$ \\
\hline & & $2.27 \mathrm{E}+08$ & $1.01 \mathrm{E}+05$ & 16.6 & 0.073 & $7.655 \mathrm{E}-02$ & $3.36 \mathrm{E}+03$ \\
\hline & R11 & $2.14 \mathrm{E}+08$ & $1.75 \mathrm{E}+04$ & 17.2 & 0.054 & 7.397E-02 & $8.58 \mathrm{E}+02$ \\
\hline & R13 & $8.96 \mathrm{E}+07$ & $1.02 \mathrm{E}+05$ & 17.2 & 0.086 & $7.397 \mathrm{E}-02$ & $7.49 \mathrm{E}+03$ \\
\hline
\end{tabular}




\begin{tabular}{|c|c|c|c|c|c|c|c|}
\hline \multirow{10}{*}{ Benzene } & \multirow{2}{*}{$\begin{array}{l}\text { R1 } \\
\text { R2 }\end{array}$} & \multirow[t]{2}{*}{$3.83 \mathrm{E}+09$} & & & 0.047 & $2.953 \mathrm{E}-01$ & \\
\hline & & & & 17 & 0.09 & 2.684E-01 & \\
\hline & $\mathbf{R 5}$ & & $8.58 \mathrm{E}+05$ & 17 & 0.143 & $2.684 \mathrm{E}-01$ & \\
\hline & R6 & $3.49 \mathrm{E}+09$ & & 17 & 0.138 & $2.684 \mathrm{E}-01$ & \\
\hline & R7 & & & 17 & 0.068 & 2.684E-01 & \\
\hline & $\mathbf{R 8}$ & $5.47 \mathrm{E}+09$ & $2.61 \mathrm{E}+05$ & 17.5 & 0.126 & $2.618 \mathrm{E}-01$ & $3.68 \mathrm{E}+01$ \\
\hline & R9 & $4.43 \mathrm{E}+09$ & $9.77 \mathrm{E}+04$ & 17.2 & 0.088 & $2.657 \mathrm{E}-01$ & $2.40 \mathrm{E}+01$ \\
\hline & R10B & $3.22 \mathrm{E}+09$ & $8.17 \mathrm{E}+04$ & 16.6 & 0.073 & $2.738 \mathrm{E}-01$ & $3.23 \mathrm{E}+01$ \\
\hline & R11 & $3.36 \mathrm{E}+09$ & $2.01 \mathrm{E}+04$ & 17.2 & 0.054 & $2.657 \mathrm{E}-01$ & $1.06 \mathrm{E}+01$ \\
\hline & R13 & $3.03 \mathrm{E}+09$ & & 17.2 & 0.086 & $2.657 \mathrm{E}-01$ & \\
\hline \multirow{10}{*}{ Toluene } & $\mathbf{R 1}$ & $3.41 \mathrm{E}+09$ & & 15.1 & 0.047 & $2.494 \mathrm{E}-01$ & \\
\hline & $\mathbf{R 2}$ & & $7.10 \mathrm{E}+04$ & 17 & 0.09 & $2.262 \mathrm{E}-01$ & \\
\hline & R5 & & $5.20 \mathrm{E}+04$ & 17 & 0.143 & $2.262 \mathrm{E}-01$ & \\
\hline & R6 & $7.16 \mathrm{E}+09$ & $6.92 \mathrm{E}+04$ & 17 & 0.138 & $2.262 \mathrm{E}-01$ & $8.84 \mathrm{E}+00$ \\
\hline & $\mathbf{R 7}$ & & & 17 & 0.068 & $2.262 \mathrm{E}-01$ & \\
\hline & R8 & $3.27 \mathrm{E}+09$ & $8.58 \mathrm{E}+04$ & 17.5 & 0.126 & $2.205 \mathrm{E}-01$ & $2.69 \mathrm{E}+01$ \\
\hline & R9 & $3.96 \mathrm{E}+09$ & $1.23 \mathrm{E}+05$ & 17.2 & 0.088 & $2.239 \mathrm{E}-01$ & $4.49 \mathrm{E}+01$ \\
\hline & R10B & $3.11 \mathrm{E}+09$ & $2.18 \mathrm{E}+04$ & 16.6 & 0.073 & $2.309 \mathrm{E}-01$ & $1.19 \mathrm{E}+01$ \\
\hline & R11 & $1.15 \mathrm{E}+09$ & $2.86 \mathrm{E}+04$ & 17.2 & 0.054 & $2.239 \mathrm{E}-01$ & $5.88 \mathrm{E}+01$ \\
\hline & R13 & $5.43 \mathrm{E}+08$ & $6.45 \mathrm{E}+04$ & 17.2 & 0.086 & $2.239 \mathrm{E}-01$ & $1.76 \mathrm{E}+02$ \\
\hline \multirow{10}{*}{ Ethylbenzene } & $\mathbf{R 1}$ & $2.18 \mathrm{E}+09$ & & 15.1 & 0.047 & $2.191 \mathrm{E}-01$ & \\
\hline & $\mathbf{R 2}$ & & $4.26 \mathrm{E}+04$ & 17 & 0.09 & $1.983 \mathrm{E}-01$ & \\
\hline & R5 & & $2.87 \mathrm{E}+04$ & 17 & 0.143 & $1.983 \mathrm{E}-01$ & \\
\hline & R6 & $1.11 \mathrm{E}+09$ & $3.99 \mathrm{E}+04$ & 17 & 0.138 & $1.983 \mathrm{E}-01$ & $5.00 \mathrm{E}+01$ \\
\hline & R7 & & & 17 & 0.068 & $1.983 \mathrm{E}-01$ & \\
\hline & R8 & $3.25 \mathrm{E}+08$ & $5.10 \mathrm{E}+04$ & 17.5 & 0.126 & $1.932 \mathrm{E}-01$ & $2.46 \mathrm{E}+02$ \\
\hline & $\mathbf{R 9}$ & $6.77 \mathrm{E}+08$ & $7.59 \mathrm{E}+04$ & 17.2 & 0.088 & $1.962 \mathrm{E}-01$ & $2.48 \mathrm{E}+02$ \\
\hline & R10B & $2.94 \mathrm{E}+08$ & $1.16 \mathrm{E}+04$ & 16.6 & 0.073 & $2.025 \mathrm{E}-01$ & $1.02 \mathrm{E}+02$ \\
\hline & R11 & $1.95 \mathrm{E}+07$ & $1.66 \mathrm{E}+04$ & 17.2 & 0.054 & $1.962 \mathrm{E}-01$ & $3.06 \mathrm{E}+03$ \\
\hline & R13 & & $3.86 \mathrm{E}+04$ & 17.2 & 0.086 & $1.962 \mathrm{E}-01$ & \\
\hline \multirow{10}{*}{ m-p-xylene } & $\mathbf{R} 1$ & $1.08 \mathrm{E}+09$ & $7.94 \mathrm{E}+03$ & 15.1 & 0.047 & $2.304 \mathrm{E}-01$ & $2.74 \mathrm{E}+01$ \\
\hline & $\mathbf{R 2}$ & & $3.91 \mathrm{E}+04$ & 17 & 0.09 & $2.094 \mathrm{E}-01$ & \\
\hline & R5 & & $2.69 \mathrm{E}+04$ & 17 & 0.143 & $2.094 \mathrm{E}-01$ & \\
\hline & R6 & $2.49 \mathrm{E}+09$ & $8.64 \mathrm{E}+04$ & 17 & 0.138 & $2.094 \mathrm{E}-01$ & $4.81 \mathrm{E}+01$ \\
\hline & R7 & & $5.91 \mathrm{E}+03$ & 17 & 0.068 & $2.094 \mathrm{E}-01$ & \\
\hline & R8 & $9.57 \mathrm{E}+08$ & $3.41 \mathrm{E}+04$ & 17.5 & 0.126 & $2.042 \mathrm{E}-01$ & $5.52 \mathrm{E}+01$ \\
\hline & R9 & $9.89 \mathrm{E}+08$ & $1.53 \mathrm{E}+04$ & 17.2 & 0.088 & $2.073 \mathrm{E}-01$ & $3.40 \mathrm{E}+01$ \\
\hline & R10B & $5.42 \mathrm{E}+08$ & $1.66 \mathrm{E}+04$ & 16.6 & 0.073 & $2.136 \mathrm{E}-01$ & $7.86 \mathrm{E}+01$ \\
\hline & R11 & $6.83 \mathrm{E}+08$ & $1.13 \mathrm{E}+04$ & 17.2 & 0.054 & $2.073 \mathrm{E}-01$ & $5.89 \mathrm{E}+01$ \\
\hline & R13 & & $2.09 \mathrm{E}+04$ & 17.2 & 0.086 & $2.073 \mathrm{E}-01$ & \\
\hline \multirow{6}{*}{ o-xylene } & $\mathbf{R 1}$ & $3.31 \mathrm{E}+08$ & $4.37 \mathrm{E}+03$ & 15.1 & 0.047 & 2.304E-01 & $4.87 \mathrm{E}+01$ \\
\hline & $\mathbf{R 2}$ & & $2.88 \mathrm{E}+04$ & 17 & 0.09 & $2.094 \mathrm{E}-01$ & \\
\hline & R5 & & $2.22 \mathrm{E}+04$ & 17 & 0.143 & $2.094 \mathrm{E}-01$ & \\
\hline & R6 & $7.47 \mathrm{E}+08$ & $7.25 \mathrm{E}+04$ & 17 & 0.138 & $2.094 \mathrm{E}-01$ & $1.33 \mathrm{E}+02$ \\
\hline & R7 & & $3.71 \mathrm{E}+03$ & 17 & 0.068 & $2.094 \mathrm{E}-01$ & \\
\hline & $\mathbf{R 8}$ & $2.68 \mathrm{E}+08$ & $1.93 \mathrm{E}+04$ & 17.5 & 0.126 & $2.042 \mathrm{E}-01$ & $1.10 \mathrm{E}+02$ \\
\hline
\end{tabular}




\begin{tabular}{|c|c|c|c|c|c|c|c|}
\hline & \multirow{4}{*}{$\begin{array}{c}\text { R9 } \\
\text { R10B } \\
\text { R11 } \\
\text { R13 }\end{array}$} & $3.70 \mathrm{E}+08$ & $8.42 \mathrm{E}+03$ & 17.2 & 0.088 & $2.073 \mathrm{E}-01$ & $4.94 \mathrm{E}+01$ \\
\hline & & $4.26 \mathrm{E}+08$ & $1.21 \mathrm{E}+04$ & 16.6 & 0.073 & $2.136 \mathrm{E}-01$ & $7.25 \mathrm{E}+01$ \\
\hline & & $2.11 \mathrm{E}+08$ & $6.96 \mathrm{E}+03$ & 17.2 & 0.054 & $2.073 \mathrm{E}-01$ & $1.17 \mathrm{E}+02$ \\
\hline & & & $1.42 \mathrm{E}+04$ & 17.2 & 0.086 & $2.073 \mathrm{E}-01$ & \\
\hline \multirow{10}{*}{$\begin{array}{c}1,3,5- \\
\text { trimethylbenzene }\end{array}$} & \multirow{10}{*}{$\begin{array}{c}\text { R1 } \\
\text { R2 } \\
\text { R5 } \\
\text { R6 } \\
\text { R7 } \\
\text { R8 } \\
\text { R9 } \\
\text { R10B } \\
\text { R11 } \\
\text { R13 }\end{array}$} & $4.71 \mathrm{E}+09$ & $3.52 \mathrm{E}+03$ & 15.1 & 0.047 & $2.15 \mathrm{E}-01$ & $3.13 \mathrm{E}+00$ \\
\hline & & & $8.37 \mathrm{E}+03$ & 17 & 0.09 & $2.01 \mathrm{E}-01$ & \\
\hline & & & $2.03 \mathrm{E}+05$ & 17 & 0.143 & $2.01 \mathrm{E}-01$ & \\
\hline & & $2.32 \mathrm{E}+08$ & & 17 & 0.138 & 2.01E-01 & \\
\hline & & & & 17 & 0.068 & 2.01E-01 & \\
\hline & & $5.24 \mathrm{E}+08$ & $2.21 \mathrm{E}+03$ & 17.5 & 0.126 & $1.97 \mathrm{E}-01$ & $7.11 \mathrm{E}+00$ \\
\hline & & $1.06 \mathrm{E}+09$ & $3.61 \mathrm{E}+03$ & 17.2 & 0.088 & $1.99 \mathrm{E}-01$ & $8.15 \mathrm{E}+00$ \\
\hline & & $8.62 \mathrm{E}+08$ & $3.60 \mathrm{E}+03$ & 16.6 & 0.073 & 2.03E-01 & $1.18 \mathrm{E}+01$ \\
\hline & & $5.08 \mathrm{E}+07$ & $2.92 \mathrm{E}+01$ & 17.2 & 0.054 & $1.99 \mathrm{E}-01$ & $2.24 \mathrm{E}+00$ \\
\hline & & $1.26 \mathrm{E}+09$ & $9.76 \mathrm{E}+03$ & 17.2 & 0.086 & $1.99 \mathrm{E}-01$ & $1.90 \mathrm{E}+01$ \\
\hline \multirow{10}{*}{$\begin{array}{c}1,2,4- \\
\text { trimethylbenzene }\end{array}$} & \multirow{10}{*}{$\begin{array}{c}\text { R1 } \\
\text { R2 } \\
\text { R5 } \\
\text { R6 } \\
\text { R7 } \\
\text { R8 } \\
\text { R9 } \\
\text { R10B } \\
\text { R11 } \\
\text { R13 } \\
\end{array}$} & $5.22 \mathrm{E}+08$ & $1.01 \mathrm{E}+04$ & 15.1 & 0.047 & $3.51 \mathrm{E}-01$ & 4.93E+01 \\
\hline & & & $9.59 \mathrm{E}+03$ & 17 & 0.09 & $3.24 \mathrm{E}-01$ & \\
\hline & & & $1.28 \mathrm{E}+04$ & 17 & 0.143 & $3.24 \mathrm{E}-01$ & \\
\hline & & $8.05 \mathrm{E}+08$ & $7.99 \mathrm{E}+03$ & 17 & 0.138 & 3.24E-01 & $9.34 \mathrm{E}+00$ \\
\hline & & & $5.48 \mathrm{E}+03$ & 17 & 0.068 & $3.24 \mathrm{E}-01$ & \\
\hline & & $1.37 \mathrm{E}+07$ & $9.90 \mathrm{E}+03$ & 17.5 & 0.126 & $3.17 \mathrm{E}-01$ & $7.56 \mathrm{E}+02$ \\
\hline & & $9.23 \mathrm{E}+07$ & $1.28 \mathrm{E}+03$ & 17.2 & 0.088 & $3.21 \mathrm{E}-01$ & $2.06 \mathrm{E}+01$ \\
\hline & & $3.16 \mathrm{E}+07$ & $1.12 \mathrm{E}+04$ & 16.6 & 0.073 & $3.29 \mathrm{E}-01$ & $6.20 \mathrm{E}+02$ \\
\hline & & & $4.31 \mathrm{E}+03$ & 17.2 & 0.054 & $3.21 \mathrm{E}-01$ & \\
\hline & & $1.25 \mathrm{E}+08$ & $1.18 \mathrm{E}+04$ & 17.2 & 0.086 & $3.21 \mathrm{E}-01$ & $1.44 \mathrm{E}+02$ \\
\hline \multirow{10}{*}{$\begin{array}{c}1,2,3- \\
\text { trimethylbenzene }\end{array}$} & \multirow{10}{*}{$\begin{array}{c}\text { R1 } \\
\text { R2 } \\
\text { R5 } \\
\text { R6 } \\
\text { R7 } \\
\text { R8 } \\
\text { R9 } \\
\text { R10B } \\
\text { R11 } \\
\text { R13 } \\
\end{array}$} & $4.62 \mathrm{E}+07$ & $1.33 \mathrm{E}+03$ & 15.1 & 0.047 & $4.08 \mathrm{E}-01$ & $6.35 \mathrm{E}+01$ \\
\hline & & & $1.35 \mathrm{E}+03$ & 17 & 0.09 & $3.68 \mathrm{E}-01$ & \\
\hline & & & $3.01 \mathrm{E}+03$ & 17 & 0.143 & $3.68 \mathrm{E}-01$ & \\
\hline & & $4.96 \mathrm{E}+07$ & $1.06 \mathrm{E}+03$ & 17 & 0.138 & $3.68 \mathrm{E}-01$ & $1.76 \mathrm{E}+01$ \\
\hline & & & $1.56 \mathrm{E}+03$ & 17 & 0.068 & $3.68 \mathrm{E}-01$ & \\
\hline & & $6.60 \mathrm{E}+08$ & $6.05 \mathrm{E}+02$ & 17.5 & 0.126 & $3.59 \mathrm{E}-01$ & \\
\hline & & $4.36 \mathrm{E}+08$ & & 17.2 & 0.088 & 3.64E-01 & \\
\hline & & $2.84 \mathrm{E}+08$ & $1.63 \mathrm{E}+03$ & 16.6 & 0.073 & $3.76 \mathrm{E}-01$ & $8.79 \mathrm{E}+00$ \\
\hline & & $2.71 \mathrm{E}+08$ & $2.62 \mathrm{E}+02$ & 17.2 & 0.054 & 3.64E-01 & $2.06 \mathrm{E}+00$ \\
\hline & & $1.06 \mathrm{E}+09$ & $1.30 \mathrm{E}+03$ & 17.2 & 0.086 & $3.64 \mathrm{E}-01$ & $1.63 \mathrm{E}+00$ \\
\hline \multirow{6}{*}{ Formaldehyde } & R4 & $4.03 \mathrm{E}+10$ & $1.809 \mathrm{E}+07$ & 17 & 0.0280 & $6.22 \mathrm{E}+03$ & $1.08 \mathrm{E}-01$ \\
\hline & $\mathbf{R 5}$ & $2.79 \mathrm{E}+11$ & $1.838 \mathrm{E}+08$ & 17 & 0.1430 & $6.22 \mathrm{E}+03$ & $3.11 \mathrm{E}-02$ \\
\hline & R6 & $4.20 \mathrm{E}+10$ & $5.259 \mathrm{E}+07$ & 17 & 0.1380 & $6.22 \mathrm{E}+03$ & $6.12 \mathrm{E}-02$ \\
\hline & R8 & $8.38 \mathrm{E}+10$ & $2.232 \mathrm{E}+08$ & 17.5 & 0.1260 & $5.96 \mathrm{E}+03$ & $1.49 \mathrm{E}-01$ \\
\hline & R9 & $3.38 \mathrm{E}+10$ & $5.091 \mathrm{E}+07$ & 17.2 & 0.0880 & $6.12 \mathrm{E}+03$ & $1.18 \mathrm{E}-01$ \\
\hline & R10B & $1.50 \mathrm{E}+10$ & $4.008 \mathrm{E}+07$ & 16.6 & 0.0730 & $6.44 \mathrm{E}+03$ & $2.39 \mathrm{E}-01$ \\
\hline \multirow{5}{*}{ Acetone } & R4 & & $6.186 \mathrm{E}+06$ & 17 & 0.0280 & $4.42 \mathrm{E}+01$ & \\
\hline & R5 & $1.32 \mathrm{E}+10$ & $2.281 \mathrm{E}+07$ & 17 & 0.1430 & $4.42 \mathrm{E}+01$ & $1.15 \mathrm{E}+01$ \\
\hline & R6 & $4.29 \mathrm{E}+10$ & $1.587 \mathrm{E}+07$ & 17 & 0.1380 & $4.42 \mathrm{E}+01$ & $2.55 \mathrm{E}+00$ \\
\hline & $\mathbf{R 8}$ & $6.97 \mathrm{E}+10$ & $1.350 \mathrm{E}+07$ & 17.5 & 0.1260 & $4.29 \mathrm{E}+01$ & $1.50 \mathrm{E}+00$ \\
\hline & R9 & $7.57 \mathrm{E}+09$ & $9.430 \mathrm{E}+06$ & 17.2 & 0.0880 & $4.37 \mathrm{E}+01$ & $1.36 \mathrm{E}+01$ \\
\hline
\end{tabular}




\begin{tabular}{|c|c|c|c|c|c|c|c|}
\hline & R10B & $1.23 \mathrm{E}+10$ & $2.461 \mathrm{E}+07$ & 16.6 & 0.0730 & $4.53 \mathrm{E}+01$ & $2.55 \mathrm{E}+01$ \\
\hline \multirow{6}{*}{ Glyoxal } & $\mathbf{R} 4$ & $2.66 \mathrm{E}+09$ & 4.214E+05 & 17 & 0.0280 & $8.38 \mathrm{E}+05$ & $2.90 \mathrm{E}-04$ \\
\hline & R5 & & $1.188 \mathrm{E}+07$ & 17 & 0.1430 & $8.38 \mathrm{E}+05$ & \\
\hline & R6 & & $1.645 \mathrm{E}+07$ & 17 & 0.1380 & $8.38 \mathrm{E}+05$ & \\
\hline & R8 & $1.01 \mathrm{E}+08$ & $6.698 \mathrm{E}+07$ & 17.5 & 0.1260 & $8.02 \mathrm{E}+05$ & $2.80 \mathrm{E}-01$ \\
\hline & R9 & $2.10 \mathrm{E}+08$ & $1.711 \mathrm{E}+07$ & 17.2 & 0.0880 & $8.23 \mathrm{E}+05$ & $4.82 \mathrm{E}-02$ \\
\hline & R10B & $2.34 \mathrm{E}+08$ & $3.735 \mathrm{E}+06$ & 16.6 & 0.0730 & $8.68 \mathrm{E}+05$ & $1.08 \mathrm{E}-02$ \\
\hline \multirow{6}{*}{ Methylglyoxal } & $\mathbf{R 4}$ & $2.01 \mathrm{E}+09$ & $3.506 \mathrm{E}+06$ & 17 & 0.0280 & $7.44 \mathrm{E}+03$ & $3.60 \mathrm{E}-01$ \\
\hline & R5 & & $1.188 \mathrm{E}+07$ & 17 & 0.1430 & $7.44 \mathrm{E}+03$ & \\
\hline & R6 & & $6.646 \mathrm{E}+06$ & 17 & 0.1380 & $7.44 \mathrm{E}+03$ & \\
\hline & R8 & $2.86 \mathrm{E}+07$ & $3.914 \mathrm{E}+07$ & 17.5 & 0.1260 & $7.12 \mathrm{E}+03$ & $6.53 \mathrm{E}+01$ \\
\hline & R9 & $3.16 \mathrm{E}+07$ & $4.980 \mathrm{E}+06$ & 17.2 & 0.0880 & $7.31 \mathrm{E}+03$ & $1.05 \mathrm{E}+01$ \\
\hline & R10B & $3.05 \mathrm{E}+07$ & $7.251 \mathrm{E}+06$ & 16.6 & 0.0730 & $7.71 \mathrm{E}+03$ & $1.81 \mathrm{E}+01$ \\
\hline
\end{tabular}


Table S9. Relative contribution of land cover uses related to the time of air masses spent over the area during calculated back trajectories for each cloud event.

\begin{tabular}{|l|c|c|c|c|}
\hline Cloud & $\begin{array}{c}\text { Coastal } \\
\text { area }\end{array}$ & $\begin{array}{c}\text { Farming } \\
\text { area }\end{array}$ & $\begin{array}{c}\text { Urban } \\
\text { area }\end{array}$ & $\begin{array}{c}\text { Vegetation } \\
\text { area }\end{array}$ \\
\hline R1 & 0.30 & 28.3 & 3.2 & 68.1 \\
\hline R2 & 4.40 & 20.6 & 3.2 & 71.7 \\
\hline R3 & 0.00 & 0.00 & 0.00 & 100 \\
\hline R4 & 0.00 & 0.00 & 0.00 & 100 \\
\hline R5 & 0.00 & 0.00 & 0.00 & 100 \\
\hline R6 & 0.00 & 0.00 & 0.00 & 100 \\
\hline R7 & 0.40 & 34.8 & 0.00 & 64.7 \\
\hline R8 & 0.00 & 0.00 & 0.00 & 100 \\
\hline R9 & 30.3 & 1.5 & 2.2 & 65.9 \\
\hline R10A & 19.2 & 38.6 & 5.9 & 36.2 \\
\hline R10B & 10.7 & 23.2 & 4.6 & 61.5 \\
\hline R11 & 1.6 & 28.6 & 1.9 & 67.8 \\
\hline R12 & 0.00 & 14.07 & 0.00 & 85.9 \\
\hline R13 & 1.3 & 14.8 & 0.8 & 83.1 \\
\hline
\end{tabular}


Table S10. Correlation matrix obtained by PLS analysis, between the land use cover matrix (the "Xs"), provided by the CAT model with the extended chemical matrix (the "Ys"), gathering four groups of compounds (inorganic ions, (di)carboxylic acids, amino acids and sugars).

\begin{tabular}{|c|c|c|c|c|c|c|}
\hline Group of compounds & Variables & $\begin{array}{c}\text { Coastal } \\
\text { area }\end{array}$ & $\begin{array}{c}\text { Farming } \\
\text { area }\end{array}$ & $\begin{array}{c}\text { Urban } \\
\text { area }\end{array}$ & Vegetation & LWC \\
\hline \multirow{4}{*}{ Land use area } & Coastal area & 1.00 & 0.13 & 0.60 & -0.62 & 0.08 \\
\hline & Farming area & 0.13 & 1.00 & 0.65 & -0.86 & -0.27 \\
\hline & Urban area & 0.60 & 0.65 & 1.00 & -0.85 & -0.07 \\
\hline & Vegetation & -0.62 & -0.86 & -0.85 & 1.00 & 0.17 \\
\hline Microphysics & LWC & 0.08 & -0.27 & -0.07 & 0.17 & 1.00 \\
\hline \multirow{8}{*}{ Ions } & $\mathrm{Na}^{+}$ & -0.16 & 0.54 & -0.11 & -0.31 & -0.30 \\
\hline & $\mathrm{NH}_{4}^{+}$ & -0.12 & 0.51 & 0.11 & -0.33 & -0.25 \\
\hline & $\mathrm{K}^{+}$ & -0.20 & 0.22 & -0.16 & -0.06 & -0.40 \\
\hline & $\mathrm{Mg}^{2+}$ & -0.23 & 0.51 & -0.16 & -0.25 & -0.33 \\
\hline & $\mathrm{Ca}^{2+}$ & -0.18 & 0.27 & -0.17 & -0.10 & -0.39 \\
\hline & $\mathrm{Cl}^{-}$ & -0.15 & 0.53 & -0.06 & -0.31 & -0.31 \\
\hline & $\mathrm{NO}_{3}^{-}$ & -0.11 & 0.43 & -0.06 & -0.26 & -0.34 \\
\hline & $\mathrm{SO}_{4}^{2-}$ & -0.29 & 0.07 & -0.20 & 0.10 & -0.48 \\
\hline \multirow{14}{*}{ Amino Acids } & Alanine & -0.06 & 0.36 & 0.12 & -0.24 & -0.12 \\
\hline & Arginine & 0.06 & 0.34 & 0.16 & -0.29 & 0.01 \\
\hline & Asparagine & 0.00 & 0.53 & 0.31 & -0.42 & -0.12 \\
\hline & Aspartic acid & 0.02 & 0.42 & 0.24 & -0.34 & -0.08 \\
\hline & Glutamine & -0.03 & 0.39 & 0.19 & -0.29 & -0.13 \\
\hline & Glutamic acid & 0.11 & 0.47 & 0.32 & -0.43 & -0.07 \\
\hline & Histidine & -0.04 & 0.31 & 0.13 & -0.22 & -0.06 \\
\hline & Lysine & -0.09 & 0.36 & 0.12 & -0.23 & -0.10 \\
\hline & Methionine & -0.28 & -0.31 & -0.33 & 0.39 & -0.54 \\
\hline & Phenylalanine & -0.15 & 0.33 & 0.08 & -0.18 & 0.07 \\
\hline & Serine & 0.00 & 0.42 & 0.26 & -0.33 & -0.09 \\
\hline & Threonine & -0.06 & 0.47 & 0.25 & -0.34 & -0.16 \\
\hline & Tryptophan & -0.32 & 0.01 & -0.15 & 0.16 & -0.36 \\
\hline & Tyrosine & -0.42 & 0.30 & -0.10 & -0.01 & -0.15 \\
\hline \multirow{10}{*}{ Sugars } & Arabitol & -0.17 & 0.27 & 0.00 & -0.12 & -0.25 \\
\hline & Erythriol & -0.09 & 0.03 & -0.24 & 0.04 & -0.29 \\
\hline & Galactosan & -0.07 & 0.42 & 0.26 & -0.30 & -0.11 \\
\hline & Glucose & -0.16 & 0.33 & 0.06 & -0.17 & -0.43 \\
\hline & Glycerol & 0.25 & 0.25 & 0.30 & -0.33 & -0.39 \\
\hline & Inositol & -0.19 & 0.30 & -0.06 & -0.12 & -0.25 \\
\hline & Levoglucosan & -0.27 & 0.12 & -0.03 & 0.04 & -0.02 \\
\hline & Mannitol & -0.19 & 0.38 & 0.05 & -0.20 & -0.16 \\
\hline & Sorbitol & -0.04 & 0.25 & -0.05 & -0.16 & -0.22 \\
\hline & Threalose & -0.03 & 0.24 & 0.02 & -0.16 & -0.25 \\
\hline \multirow{2}{*}{ Carboxylic acids } & Acetic acid & -0.23 & 0.13 & -0.20 & 0.03 & -0.21 \\
\hline & Formic acid & -0.41 & 0.27 & -0.17 & 0.01 & -0.48 \\
\hline \multirow{18}{*}{ Dicarboxylic acids } & 3-MBTCA & -0.11 & 0.46 & 0.17 & -0.30 & -0.18 \\
\hline & Adipic acid & 0.25 & 0.44 & 0.63 & -0.50 & -0.17 \\
\hline & Azelaic acid & -0.21 & 0.21 & -0.02 & -0.05 & -0.47 \\
\hline & Citraconic acid & -0.22 & 0.24 & -0.31 & -0.04 & 0.25 \\
\hline & Fumaric acid & -0.10 & 0.55 & 0.06 & -0.36 & 0.00 \\
\hline & Glutaric acid & -0.26 & 0.46 & -0.04 & -0.21 & -0.32 \\
\hline & Lactic acid & -0.24 & 0.17 & 0.07 & -0.02 & 0.08 \\
\hline & Maleic acid & -0.06 & 0.25 & -0.20 & -0.13 & 0.25 \\
\hline & Malic acid & 0.16 & 0.64 & 0.35 & -0.58 & 0.08 \\
\hline & Malonic acid & 0.34 & 0.66 & 0.65 & -0.71 & 0.06 \\
\hline & MethylGlutaric acid & -0.04 & 0.47 & 0.09 & -0.33 & 0.13 \\
\hline & MethylSuccinic acid & -0.03 & 0.60 & 0.14 & -0.44 & -0.04 \\
\hline & Oxalic acid & -0.27 & 0.20 & 0.14 & -0.04 & -0.08 \\
\hline & Phthalic acid & 0.03 & 0.41 & 0.31 & -0.35 & -0.14 \\
\hline & Pinic acid & -0.24 & 0.16 & -0.16 & 0.01 & 0.04 \\
\hline & Sebacic acid & 0.26 & 0.56 & 0.50 & -0.58 & -0.13 \\
\hline & Suberic acid & -0.19 & 0.21 & 0.09 & -0.08 & -0.52 \\
\hline & Succinic acid & 0.13 & 0.71 & 0.47 & -0.63 & -0.11 \\
\hline
\end{tabular}




\section{References}

Alves, R. F., Nascimento, A. M. D. and Nogueira, J. M. F.: Characterization of the aroma profile of Madeira wine by sorptive extraction techniques, Anal. Chim. Acta, 546(1), 11-21, doi:10.1016/j.aca.2005.05.012, 2005.

Ang, C. C., Lipari, F. and Swarin, S. J.: Determination of Hydroxymethanesulfonate in Wet Deposition Samples, Environ. Sci. Technol., 21(1), 102-105, doi:10.1021/es00155a013, 1987.

Audiffren, N., Renard, M., Buisson, E. and Chaumerliac, N.: Deviations from the Henry's law equilibrium during cloud events: a numerical approach of the mass transfer between phases and its specific numerical effects, Atmos. Res., 49(2), 139-161, doi:10.1016/S0169-8095(98)00072-6, 1998.

Benedict, K. B., Lee, T. and Collett, J. L.: Cloud water composition over the southeastern Pacific Ocean during the VOCALS regional experiment, Atmos. Environ., 46, 104-114, doi:10.1016/j.atmosenv.2011.10.029, 2012.

Bianco, A.: Formation photoinduite du radical hydroxyle dans la phase aqueuse du nuage : impact sur les acides carboxyliques et les acides aminés, Université Blaise Pascal - Clermont-Ferrand II., 2016.

Bianco, A., Passananti, M., Perroux, H., Voyard, G., Mouchel-Vallon, C., Chaumerliac, N., Mailhot, G., Deguillaume, L. and Brigante, M.: A better understanding of hydroxyl radical photochemical sources in cloud waters collected at the puy de Dôme station - Experimental versus modelled formation rates, Atmos. Chem. Phys., 15(16), 9191-9202, doi:10.5194/acp-15-9191-2015, 2015 .

Bianco, A., Passananti, M., Brigante, M. and Mailhot, G.: Photochemistry of the Cloud Aqueous Phase : A Review, Molecules, 25(423), 1-23, doi:10.3390/molecules25020423, 2020.

Coelho, E., Coimbra, M. A., Nogueira, J. M. F. and Rocha, S. M.: Quantification approach for assessment of sparkling wine volatiles from different soils, ripening stages, and varieties by stir bar sorptive extraction with liquid desorption, Anal. Chim. Acta, 635(2), 214-221, doi:10.1016/j.aca.2009.01.013, 2009.

Dasgupta, P. K., DeCesare, K. and Ullrey, J. C.: Determination of atmospheric sulfur dioxide without tetrachloromercurate(II) and the mechanism of the Schiff reaction, Anal. Chem., 52(12), 1912-1922, doi:10.1021/ac50062a031, 1980.

Deguillaume, L., Charbouillot, T., Joly, M., Vaïtilingom, M., Parazols, M., Marinoni, A., Amato, P., Delort, A. M., Vinatier, V., Flossmann, A., Chaumerliac, N., Pichon, J. M., Houdier, S., Laj, P., Sellegri, K., Colomb, A., Brigante, M. and Mailhot, G.: Classification of clouds sampled at the puy de Dôme (France) based on $10 \mathrm{yr}$ of monitoring of their physicochemical properties, Atmos. Chem. Phys., 14(3), 1485-1506, doi:10.5194/acp-14-1485-2014, 2014.

Fischer, H., Pozzer, A., Schmitt, T., Jöckel, P., Klippel, T., Taraborrelli, D. and Lelieveld, J.: Hydrogen peroxide in the marine boundary layer over the South Atlantic during the OOMPH cruise in March 2007, Atmos. Chem. Phys., 15(12), 6971-6980, doi:10.5194/acp-15-6971-2015, 2015.

Hoerger, C. C., Claude, A., Plass-Duelmer, C., Reimann, S., Eckart, E., Steinbrecher, R., Aalto, J., Arduini, J., Bonnaire, N., Cape, J. N., Colomb, A., Connolly, R., Diskova, J., Dumitrean, P., Ehlers, C., Gros, V., Hakola, H., Hill, M. and Hopkins, J. R.: ACTRIS non-methane hydrocarbon intercomparison experiment in Europe to support WMO GAW and EMEP observation networks, Atmos. Meas. Tech, 8, 2715-2736, doi:10.5194/amt-8-2715-2015, 2015.

Houdier, S., Perrier, S., Defrancq, E. and Legrand, M.: A new fluorescent probe for sensitive detection of carbonyl compounds: Sensitivity improvement and application to environmental water samples, Anal. Chim. Acta, 412(1-2), 221-233, doi:10.1016/S0003-2670(99)00875-2, 2000.

Houdier, S., Barret, M., Dominé, F., Charbouillot, T., Deguillaume, L. and Voisin, D.: Sensitive determination of glyoxal, methylglyoxal and hydroxyacetaldehyde in environmental water samples by using dansylacetamidooxyamine derivatization and liquid chromatography/fluorescence, Anal. Chim. Acta, 704(1-2), 162-173, doi:10.1016/j.aca.2011.08.002, 2011.

Houdier, S., Lévêque, J., Sabatier, T., Jacob, V. and Jaffrezo, J. L.: Aniline-based catalysts as promising tools to improve analysis of carbonyl compounds through derivatization techniques: preliminary results using dansylacetamidooxyamine derivatization and LC-fluorescence, Anal. Bioanal. Chem., 410(27), 7031-7042, doi:10.1007/s00216-018-1304-3, 2018.

Junkermann, W. and Stockwell, W. R.: On the budget of photooxidants in the marine boundary layer of the tropical South Atlantic, J. Geophys. Res. Atmos., 104(D7), 8039-8046, doi:10.1029/1998JD100060, 1999.

Kawaguchi, M., Sakui, N., Okanouchi, N., Ito, R., Saito, K. and Nakazawa, H.: Stir bar sorptive extraction and trace analysis of alkylphenols in water samples by thermal desorption with in tube silylation and gas chromatography-mass spectrometry, J. Chromatogr. A, 1062(1), 23-29, doi:10.1016/j.chroma.2004.11.033, 2005.

Kruisz, C., Berner, A. and Brandner, B.: A cloud water sampler for high wind speeds, in Proceedings of the EUROTRAC Symposium 1992, edited by W. Borrell, P.M., Borrell, P., Cvitas, T., Seiler and 30 (Eds.), pp. 523-525, SPB Academic Publishing., 1993.

Marinoni, A., Laj, P., Sellegri, K. and Mailhot, G.: Cloud chemistry at the Puy de Dôme: Variability and relationships with environmental factors, Atmos. Chem. Phys., 4(3), 715-728, doi:10.5194/acp-4-715-2004, 2004. 
McElroy, W. J.: Sources of hydrogen peroxide in cloudwater, Atmos. Environ., 20(3), 427-438, doi:10.1016/00046981(86)90082-X, 1986.

Mouchel-Vallon, C., Deguillaume, L., Monod, A., Perroux, H., Rose, C., Ghigo, G., Long, Y., Leriche, M., Aumont, B., Patryl, L., Armand, P. and Chaumerliac, N.: CLEPS 1.0: A new protocol for cloud aqueous phase oxidation of VOC mechanisms, Geosci. Model Dev., 10(3), 1339-1362, doi:10.5194/gmd-10-1339-2017, 2017.

Munger, J. W., Jacob, D. J. and Hoffmann, M. R.: The occurrence of bisulfite-aldehyde addition products in fog- and cloudwater, J. Atmos. Chem., 1(4), 335-350, doi:10.1007/BF00053799, 1984.

O’Sullivan, D. W., Heikes, B. G., Lee, M., Chang, W., Gregory, G. L., Blake, D. R. and Sachse, G. W.: Distribution of hydrogen peroxide and methylhydroperoxide over the Pacific and South Atlantic Oceans, J. Geophys. Res. Atmos., 104(D5), 5635-5646, doi:10.1029/98JD01250, 1999.

Ochiai, N., Sasamoto, K., Takino, M., Yamashita, S., Daishima, S., Heiden, A. and Hoffman, A.: Determination of trace amounts of off-flavor compounds in drinking water by stir bar sorptive extraction and thermal desorption GC-MS, Analyst, 126(10), 16521657, doi:10.1039/b102962m, 2001.

Pang, X., Lewis, A. C. and Hamilton, J. F.: Determination of airborne carbonyls via pentafluorophenylhydrazine derivatisation by GC-MS and its comparison with HPLC method, Talanta, 85(1), 406-414, doi:10.1016/j.talanta.2011.03.072, 2011.

van Pinxteren, D., Plewka, A., Hofmann, D., Müller, K., Kramberger, H., Svrcina, B., Bächmann, K., Jaeschke, W., Mertes, S., Collett, J. L. and Herrmann, H.: Schmücke hill cap cloud and valley stations aerosol characterisation during FEBUKO (II): Organic compounds, Atmos. Environ., 39(23-24), 4305-4320, doi:10.1016/j.atmosenv.2005.02.014, 2005.

Portugal, F. C. M., Pinto, M. L. and Nogueira, J. M. F.: Optimization of Polyurethane Foams for Enhanced Stir Bar Sorptive Extraction of Triazinic Herbicides in Water Matrices, Talanta, 77(2), 765-773, doi:10.1016/j.talanta.2008.07.026, 2008.

Renard, P., Brissy, M., Rossi, F., Leremboure, M., Jaber, S., Baray, J.-L., Bianco, A., Delort, A.-M. and Deguillaume, L.: Free amino acids measurements in cloud water at the puy de Dôme station, Atmos. Chem. Phys. Discuss, 2021.

Rossignol, S., Chiappini, L., Perraudin, E., Rio, C., Fable, S., Valorso, R. and Doussin, J. F.: Development of a parallel sampling and analysis method for the elucidation of gas/particle partitioning of oxygenated semi-volatile organics: A limonene ozonolysis study, Atmos. Meas. Tech., 5(6), 1459-1489, doi:10.5194/amt-5-1459-2012, 2012.

Samaké, A., Jaffrezo, J. L., Favez, O., Weber, S., Jacob, V., Albinet, A., Riffault, V., Perdrix, E., Waked, A., Golly, B., Salameh, D., Chevrier, F., Miguel Oliveira, D., Bonnaire, N., Besombes, J. L., Martins, J. M. F., Conil, S., Guillaud, G., Mesbah, B., Rocq, B., Robic, P. Y., Hulin, A., Le Meur, S., Descheemaecker, M., Chretien, E., Marchand, N. and Uzu, G.: Polyols and glucose particulate species as tracers of primary biogenic organic aerosols at 28 French sites, Atmos. Chem. Phys., 19(5), 3357-3374, doi:10.5194/acp-19-3357-2019, 2019.

Sander, R.: Compilation of Henry's law constants (version 4.0) for water as solvent, Atmos. Chem. Phys., 15(8), 4399-4981, doi:10.5194/acp-15-4399-2015, 2015.

Stookey, L. L.: Ferrozine-A New Spectrophotometric Reagent for Iron, Anal. Chem., 42(7), 779-781, doi:10.1021/ac60289a016, 1970 .

Tredoux, A., De Villiers, A., Májek, P., Lynen, F., Crouch, A. and Sandra, P.: Stir bar sorptive extraction combined with GC-MS analysis and chemometric methods for the classification of South African wines according to the volatile composition, J. Agric. Food Chem., 56(12), 4286-4296, doi:10.1021/jf0734673, 2008.

Valverde-Canossa, J., Wieprecht, W., Acker, K. and Moortgat, G. K.: H2O2 and organic peroxide measurements in an orographic cloud: The FEBUKO experiment, Atmos. Environ., 39(23-24), 4279-4290, doi:10.1016/j.atmosenv.2005.02.040, 2005.

Wang, M., Perroux, H., Fleuret, J., Bianco, A., Bouvier, L., Colomb, A., Borbon, A. and Deguillaume, L.: Anthropogenic and biogenic hydrophobic VOCs detected in clouds at the puy de Dôme station using Stir Bar Sorptive Extraction: Deviation from the Henry's law prediction, Atmos. Res., 237(July 2019), 104844, doi:10.1016/j.atmosres.2020.104844, 2020.

Weller, R., Schrems, O., Boddenberg, A., Gäb, S. and Gautrois, M.: Meridional distribution of hydroperoxides and formaldehyde in the marine boundary layer of the Atlantic $\left(48^{\circ} \mathrm{N}-35^{\circ} \mathrm{S}\right)$ measured during the Albatross campaign, J. Geophys. Res. Atmos., 105(D11), 14401-14412, doi:10.1029/1999JD901145, 2000.

Xuan, X., Chen, Z., Gong, Y., Shen, H. and Chen, S.: Partitioning of hydrogen peroxide in gas-liquid and gas-aerosol phases, Atmos. Chem. Phys., 20(9), 5513-5526, doi:10.5194/acp-20-5513-2020, 2020. 